BTDMED WM 200 F $29 \mathrm{P}$ 1922

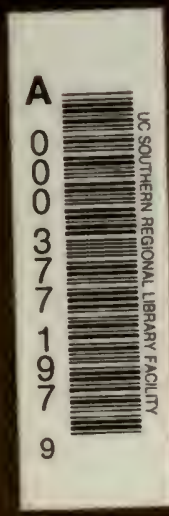




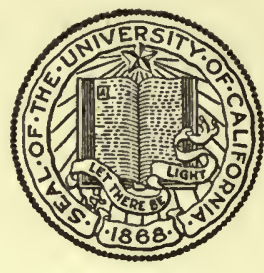

THE LIBRARY

OF

THE UNIVERSITY OF CALIFORNIA LOS ANGELES 
Nervous and Mental Disease Monograph Series No.J3

A Psychoanalytic Study of Psychoses with Endocrinoses

\author{
By \\ DUDLEY WARD FAY, PH.D.
}

WASHINGTON, O. C.

1922 


\title{
Netvous and Mental Disease Monograph Series
}

\author{
Filted be \\ SMITA BLY FELLIFER, NO.
}

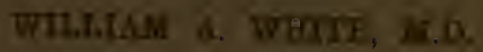

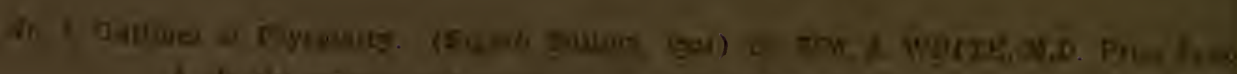

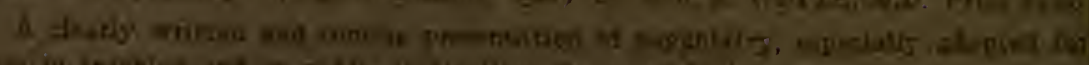

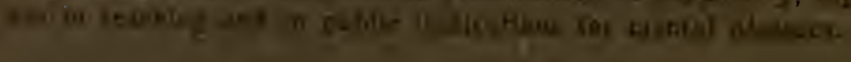

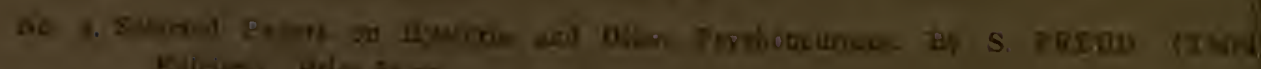
Eilicien petes it on

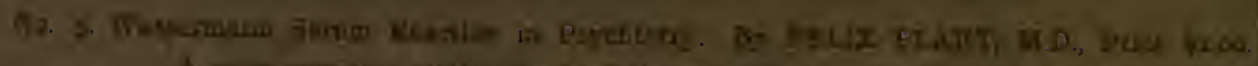

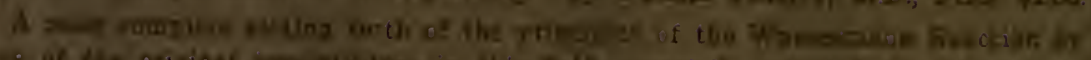

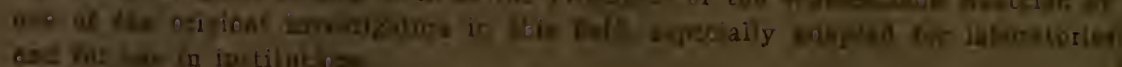

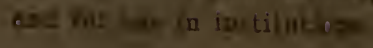

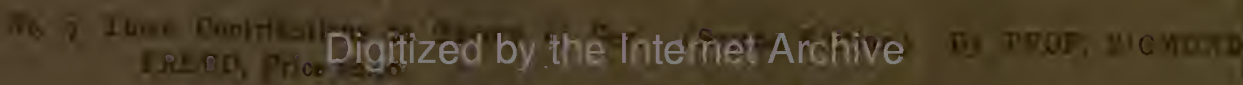

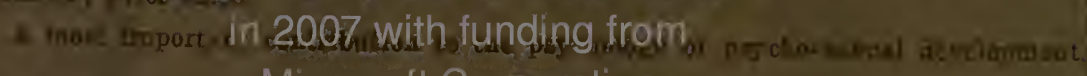

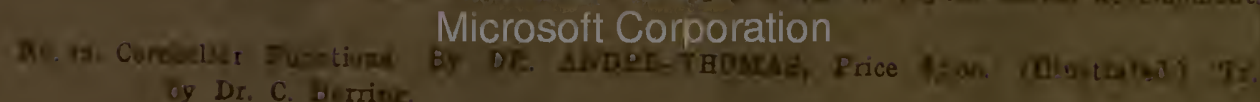
of Dr. C. Berrive.

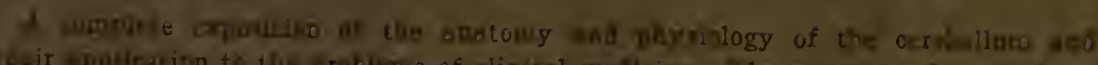

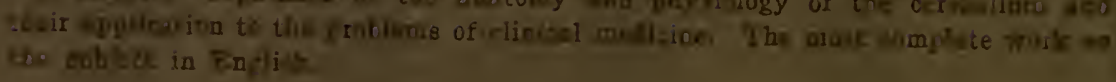

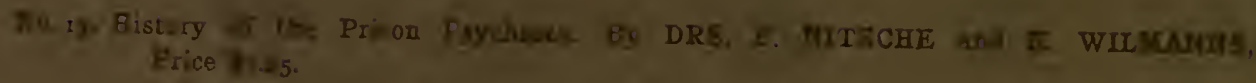

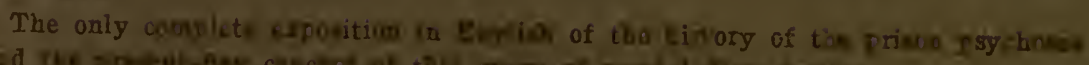

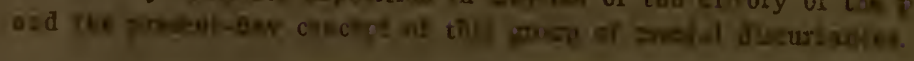

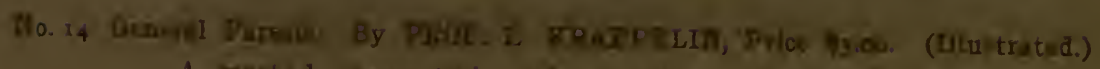

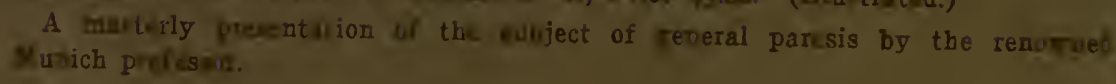
So t6. Polinoyelitu. By DR I. MnctenanN, Priod \$3.00. (Illuglrated.) Tr. by Dr. W. J.
of. Al. Walowey.

2 complete spoution of the pelinelyelfie ningtion

(Sie in is lwakt corer sases)

http://Www. archive.org/details/psychoanalyticst00faydiala - 
Nervous and Mental Disease Monograph Series No. 33

\section{A Psychoanalytic Study \\ of Psychoses with Endocrinoses}

BY

DUDLEY WARD FAY, PH.D.

NEW YORK AND WASHINGTON

NERVOUS AND MENTAL DISEASE

PUBLISHING COMPANY

1922 


\title{
NERVOUS AND MENTAL DISEASE MONOGRAPH SERIES
}

\author{
Edited by \\ Drs. SMITH ELY JELLIFFE and WM. A. WHITE \\ Numbers Issued
}

4. Outlines of Psychiatry. (8th Edition.) \$4.00. By Dr. William A. White.

2. Studies in Paranoia. (Out of Print.) By Drs. N. Gierlich and M. Friedman.

3. The Psychology of Dementia Praecox. (Out of Print.) By Dr. C. G. Jung.

4. Selected Papers on Hysteria and other Psychoneuroses. (3d Edition.) \$3.00. By

Prof. Sigmund Freud.

5. The Wassermann Serum Diagnosis in Psychiatry. \$2.00. By Dr. Felix Plaut.

6. Epidemic Poliomyelitis. New York, 1907. (Out of Print.)

7. Three Contributions to Sexual Theory. (2d Edition.) \$2.00. By Prof. Sigmund Freud.

8. Mental Mechanisms. (Out of Print.) By Dr. Wm. A. White.

9. Studies in Psychiatry. (Out of Print.) New York Psychiatrical Society.

ro. Handbook of Mental Examination Methods. (Out of Print.) By Shepherd Ivory Franz.

I1. The Theory of Schizophrenic Negativism. \$1.00. By Professor E. Bleuler.

12. Cerebellar Functions. \$3.00. By Dr. André-Thomas.

13. History of Prison Psychoses. \$1.25. By Drs. P. Nitsche and K. Wilmanns.

14. General Paresis. \$3.00. By Prof. E. Kraepelin.

15. Dreams and Myths. (Out of Print.) By Dr. Karl Abraham.

16. Poliomyelitis. \$3.00. By Dr. I. Wickmann.

17. Freud's Theories of the Neuroses. (Out of Print) By Dr. E. Hitschmann.

18. The Myth of the Birth of the Hero. \$r.oo. By Dr. Otto Rank.

19. The Theory of Psychoanalysis. (Out of Print.) By Dr. C. G. Jung.

20. Vagotonia. \$1.00. (3d Edition.) By Drs. Eppinger and Hess.

21. Wishfulfillment and Symbolism in Fairy Tales. \$1.00. By Dr. Ricklin.

22. The Dream Problem. (Out of Print.). By Dr. A. E. Maeder.

23. The Significance of Psychoanalysis for the Mental Sciences. \$1.50. By Drs. 0 . Rank and D. H. Sachs.

24. Organ Inferiority and its Psychical Compensation. \$2.00. By Dr. Alfred Adler.

25. The History of the Psychoanalytic Movement. \$1.00. By Prof. S. Freud.

26. Technique of Psychoanalysis. (2d Edition.) \$2.50. By Dr. Smith Ely Jelliffe.

27. Vegetative Neurology. \$2.50. By Dr. H. Higier.

28. The Autonomic Functions and the Personality. \$2.50. By Dr. Edward J. Kempf.

29. A Study of the Mental Life of the Child. \$2.00. By Dr. H. Von Hug-Hellmuth.

3o. Internal Secretions and the Nervous System. \$r.0o. By Dr. M. Laignel Lavastine.

31. Sleep Walking and Moon Walking. \$2.00. By Dr. J. Sadger.

32. Foundations of Psychiatry. \$3.00. By Dr. William A. White.

Copyright, 1922, by

NERVOUS AND MENTAL DISEASE PUBLISHING COMPANY

36r7 roth St. N. W., Washington, D. C. 

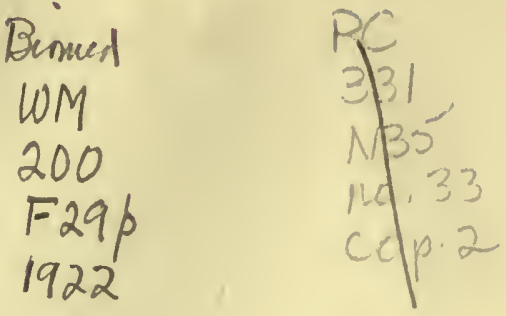

\section{CONTENTS}

FOREWORD $\ldots \ldots \ldots \ldots \ldots \ldots \ldots \ldots \ldots \ldots \ldots \ldots \ldots \ldots \ldots \ldots$

INTRODUCTION $\ldots \ldots \ldots \ldots \ldots \ldots \ldots \ldots \ldots \ldots \ldots \ldots \ldots \ldots \ldots$

CASE Histories (including in each case the life history, sex life, fantasies, general observations, the effects of occupational therapy, physical examination, endocrine diagnosis, the effects of glandular therapy, condition of the patient four months later, and the mental diagnosis)...... $\mathbf{r}$

Conclusions on Occupational Therapy ........... IO9

Conclusions on Glandular Therapy ............. I I

Conclusions on Psychoanalytic Treatment ........ I I I.

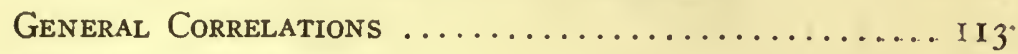

General Conclusions ................... I 8

Discussion $\ldots \ldots \ldots \ldots \ldots \ldots \ldots \ldots \ldots \ldots \ldots \ldots \ldots \ldots \ldots \ldots \ldots$ 



\section{FOREWORD}

I wish to thank Dr. William A. White, Superintendent of St. Elizabeth's Hospital, for his permission and support in making this experiment, Dr. Nolan, D. C. Lewis and Dr. Gertrude H. Davies for their assistance in studying the cases, and Dr. Shepherd Ivory Franz for his advice and criticism in preparing this thesis. Dr. Lewis furnished the reports of the physical examinaations which are included in the case histories.

The names of the patients are fictitious. In quoting their talk I have often translated obscene words into more technical language but $I$ have not altered the meaning in any way. 



\section{INTRODUCTION}

This thesis is a psychoanalytic study of twenty-two male patients in an experiment on psychoses associated with recognized endocrine disorders conducted in St. Elizabeths Hospital, Washington, D. C., by Dr. Nolan D. C. Lewis with the assistance of Dr. Gertrude H. Davies and myself. ${ }^{1}$

The object was to discover whether there was any correlation between certain endocrine disorders and certain psychotic syndromes. It is well known, of course, that there are glandular troubles among both sane and insane. According to LaignelLavastine $^{2}$ mental disorders can cause endocrine disturbances, and endocrine disturbances can cause mental disorders, or the two processes can coexist. Irrespective of which is the cart or which is the horse, it would be of value to learn what sort of mental disturbance is associated with a disorder of each particular gland or combination of glands, or vice versa.

At one time Kraepelin ${ }^{3}$ suspected there was some connection between dementia precox (or schizophrenia) and endocrine disorders, but later considered that he had failed to prove it. In the recent English translation of the portion of his work which deals with dementia precox he says: "Many years ago I endeavored for a long time to acquire influence on dementia precox by the introduction of preparations of every possible organ, of the thyroid gland, of the testes, of the ovaries, and so on, unfortunately without any result." The results of our study seem to corroborate his original hypothesis.

From the various white male wards of the hospital there was selected a group of patients who had recognizable endocrine

1 Lewis and Davies, A Correlative Study of Endocrine Imbalance and Mental Disease, Journal of Nervous and Mental Diseases, vol. 53-54, 1921.

2 Laignel-Lavastine, M., The Internal Secretions and the Nervous System, Nervous and Mental Disease Monograph Series No. 30, 1919, p. 34 .

${ }^{3}$ Dementia Praecox and Paraphrenia, 1919. 
disorders. No selection was made on a basis of mental disorder; this is important to keep in mind in view of the findings reported in later sections of this thesis. Our group included patients ranging from badly deteriorated old timers to newly admitted boys from the army, navy and civil life. What they had in common was some kind of a disorder of one or more of the ductless glands.

I purposely kept myself as much as possible in ignorance of the glandular disorders of the various patients so that my diagnosis of their mental syndromes might not be influenced by their physical condition. Only after I had drawn up the case histories and divided them into mental groups did I compare them with the physical groups and determine the correlations.

The term schizophrenia I used to denote the splitting of the mind by means of which the patient lives in two worlds, one of reality, the other of fantasy. In simple schizophrenia without projection he indulges his cravings in imagination and is at peace with himself. In schizophrenia with projection he resists his socially undesirable cravings and refuses to recognize them as originating in himself; he projects the blame on others and believes they put these immoral thoughts and wishes into his mind or even use physical force on him. The mechanism of projection grows out of his refusing to face himself and his latent possibilities for evil, but once he has developed the habit he may project the most innocent ideas as well.

In making the endocrine diagnoses not only was the physical condition of the patients examined, but they were subjected to two tests, the sugar ingestion and the thyroid feeding tests.

The experiment lasted six months. After its conclusion the ward was broken up and the patients were soon redistributed throughout the hospital. Four months later I revisited the hospital and noted the condition of all our patients who were still there. 


\section{CASE HISTORIES}

\section{ABRAMS}

History: He was a Jew thirty-four years old. His father was a carpenter and the family lived in a village of southern Russia. The boy attended the local school until his father died and his mother remarried. He then went to a school in the city of Pinsk, where he associated with boys who cared little for their studies and spent their time in each other's rooms, discussing politics and the condition of the peasants, and dreamed of strikes, boycotts and revolution. The Japanese war broke out, and the boys became pacifists hostile to the government. He philosophized and dreamed of the future but neglected school work. His only sports were swimming and skating. He did not dare try the examinations for a high diploma but obtained a diploma for work equivalent to that of an American grammar school.

By teaching during his eighteenth year he earned enough money to emigrate to the United States, and came to the home of an uncle. The first year he worked ten hours a day in a chair factory. During the next four years he attended high school mornings, worked in the factory afternoons, and taught English to a class of foreigners in the evenings. "I was just learning English myself, I had no time to dream. I had physical work in the factory which I had to do, and that was a stimulus. I felt self-supporting. I was earning my own way. I was like a soldier fighting." He was twenty-four years old when he graduated from high school.

In the autumn he entered a college that offered a three-year course leading to the degree of A.B. He managed to live the first year on two hundred dollars he had saved. During the summer vacation he earned a hundred dollars peddling aluminum kitchen ware from door to door. By December his funds were gone. The college loaned him money without interest to com- 
plete the second year. "That boosted my self respect. If I hadn't been a good student, they wouldn't have lent me it. I boasted of it to my relatives. Those were two fine years."

The college advised him to stay out a year and work to earn money to complete the final year. He went back to peddling but could not make a success of it. "College had made me finer, more classical. I didn't like peddling now. I hated to knock on doors. After two weeks I gave it up. I loafed or worked in the chair factory the rest of the summer. I didn't like that sort of work and wanted to return to college. My uncles borrowed money from banks and let me have it so I could continue my studies. And that's the reason I failed. I had no solid footing. I was living on borrowed money. I couldn't concentrate my mind. The money lent me by the college had no interest attached and so it didn't worry me. I worried over the interest my uncles had to pay. What if I failed to get a good position after I graduated and were unable to repay them. I was proud. I wanted to do it myself and not feel I had to have the help of hard-working relatives. And so I failed. I lost at both ends.

"A college education was to me a sort of religion. Most students go for practical purposes. I looked on it differently from American boys, as a spiritual endowment rather than practical. At that time I was soaring, dreaming to be a poet. But I couldn't write my thoughts as a poet does. I wasn't a soldier, do you see? I wasn't practical. I was in a passive state. I dreamed of writing, of being a professor. One of my professors said I had ' abortive sentimentalism.' Too much poetry, not enough buckling down to work. I wasted time hanging around the Y. M. C. A. playing checkers or in the gymnasium. The personality of the French teacher annoyed me. I flunked French right along and at midyears I flunked experimental psychology. In April I was suspended. That burst the bubble. After that I wanted a change of environment. I peddled for a week, worked a few days, and then went home. One of the professors wanted me to assist him in social service in a nearby city. $\mathrm{He}$ put me to work making notes on the condition of back yards, but I didn't satisfy him, and quit. I started for my married sister's home, and the train passed through the city where my 
college was situated. It was graduation time in June, and one of the professors and a student got on the train. I hid myself from them, jealous, disappointed and ashamed. I staid all summer at my sister's trying to get a job but couldn't. I had to earn money so I went to New York and got work as dishwasher in a summer hotel. It was terribly hard. In a week I quit and returned to my sister's where I attended a state normal school with free tuition and got my A.B.

"The next year I taught in a small school for boys and was able to repay part of the debt to my uncles. I got on fairly well but I didn't want to stay. I returned to my sister's and studied for an A.M. I worried over lack of money, and studied also for civil service examinations, neglecting my post-graduate work. I flunked some courses and quit in May. One of the teachers said I would have gotten my A.M. if I hadn't dreamed so much."

The ensuing year and a half was one long succession of jobs lasting anywhere from one week to six months. He worked as busboy in restaurants, translated Russian, canvassed for a magazine and a sewing machine company, sold life insurance and clerked in a store, earning just enough to live on. Half a year after the United States entered the war he enlisted in a naval aviation school. "I flunked my exams. They were too technical; I don't know mechanics. Then they transferred me to duty as a seaman in the same camp. I had to leave my class just as at college. Life was very unpleasant. A scholar hates to flunk."

Not even as seaman could he give satisfaction. He became absorbed in his own thoughts and did not seem to comprehend his duties, and often was seen smiling to himself without apparent reason. He was sent to a psychopathic ward for observation. There he lay in the sun for hours at a time. He did not resent this detention and said he had been nervous and needed a rest. There was nothing the matter with his mind, he declared, he could think and remember as well as ever. As he made no improvement he was transferred to St. Elizabeths, where he stayed in bed for several weeks and had to be tube fed for two 
days. Neither in navy or hospital did he associate with anybody. $\mathrm{He}$ denied hallucinations and delusions.

Sex life: He was very reticent about his sex history and thoughts, and resisted questioning passively but effectively, answering "I don't know. If that is universal as you say, then probably I must have experienced it also. I don't remember." He claimed to have no memory of masturbating but perhaps he had done:it as a child. He denied having heterosexual intercourse, but once when he was feeling lonely he had paid a girl to strip before him, and he stript too, but what happened after that he "couldn't remember." He liked to dance, but wasn't much of a ladies' man. They never liked him, but men did. "It is not desirable to change my temperament. I couldn't marry for I had no money. A student has no money. I didn't focus my attention on any particular girl. I wasn't ready to marry. I didn't have the time to bother-No, that isn't correct, I had lots of time." Nothing could be elicited on the subject of perversions. "I'm sure I can't remember whether I've ever heard of them or not." He used to have two or three night pollutions a month, usually after a heavy supper. He could remember no accompanying dreams.

Fantasies: Most of his time was spent in thinking, but he was disinclined to tell what about, "I don't think of anything in particular. I think of books I've read. I began day-dreaming in Russia. Here in this country students play baseball and football and haven't much time for thinking. I think of my boyhood in Russia, of my relatives, of past experiences and scenes, of people I've met, fancies, imagination. Fancy is playful, colorful imagination. I don't think of one continuous thing. I make no effort to. One thought follows another. A young man naturally has fancies, dreams of the future. As a school boy I dreamed of writing books, but I'm not good at fiction. I'm better at close thinking, reasoning, philosophy. It is impossible to think of nothing. I was evading the issue. A person doesn't like to tell his thoughts. ("Are they of love?" He snickers.) Yes, I used to study belles lettres, be romantic, but now I'm like Benjamin Franklin with both feet on the ground, a practical man. He was a good model for me. 
"At twenty-six I had romantic fancies. I was young and strong, and finally the dreams ended in sexual intercourse. But now I don't feel well, and women don't figure in them. I feast my eyes on the nurses now, a sort of mental healing."

On another day he said, "Here I sit and think. This morning I thought of our talk yesterday and of my choice of words. I tried to find better ones. Then I tried for mental exercise to orient myself, to picture the lay-out of the hospital."

On noticing a picture of a pretty girl on a calendar he smiled and said, "A picture like that evokes a smile from a young man. Yes, I like pretty girls very much, sir. ("Do you think about them much?") No sir, impossible. Well, occasionally. I hardly ever have unpleasant thought. Pretty girls, largely esthetic. I admire beauty (gives a waggish grin). I think of la femme, her beauty, her voice. My mind is supreme. I get imagining, then I realize it isn't reality, and I wake up and check myself. It's delusional, but I'm matter of fact."

General observations: He had been in the hospital a year and a half before he was admitted to the endocrine ward. His sole occupation had been to half-heartedly push a polishing block along the corridors. Although he had parole of the grounds he made no use of it, and only left the ward when forced to. Once I compelled him protesting to walk to a building several hundred feet away, and then abandoned him. He immediately turned and plodded back towards his ward, but had paid so little attention to the surroundings that he had difficulty in recognizing which building he had come from.

At our first interview he said in a whispering voice, "I feel weak, no, not weak but tired. I'm in a hospital and want to get well. I'm getting what I need, food and fresh air. Getting well and getting a rest to me seem the same thing. The Epicureans said eat, drink, and be happy. I'm contented at the way things are for the present. I'm just contented, that's all. I'm here under authority. I do what I'm told. After I'm discharged I'll visit my sister for a week, then get a job. I'm not afraid even of physical work. In an extremity I could go back to chair making. I might teach, but it's hard to find a job, for I speak 
English imperfectly, with a foreign pronunciation, and most school teachers are women anyway."

A few days later he said, "I'm not feeling very well. I felt better at college. Sitting quiet is very comfortable. I'm patiently satisfied." This last phrase pleased him immensely. He repeated it several times and said it exactly expressed his sentiments.

After explaining the self-preservative and creative impulses I asked what he loved most. "My three meals and myself, three square meals, warmth and a bed. In that respect I'm satisfied. I like woman's voice and companionship, looking at her, hearing her voice, but the meals and bed come first, more than la femme."

All day he would sit in a chair or stand gazing out a window lost in his thoughts, his lips pressed tight together and pushed forward in a pout. Sometimes he moved them back and forth. When his tray was set on a nearby table he ate standing up, though there was a chair a few steps away and another patient called his attention to it.

When I asked what he thought about so much he replied, "I think over past experiences or what I've read. Sometimes there is a vacuum and I think of and look at nothing. I just plod along. I feel satisfied. I take my situation as a matter of course. I've gotten so accustomed to this place I don't think I'll ever be discharged. I'm a stoic. I think I'm sane. I don't see how I'm insane but I really don't care. I take things as they are. ("What about your future?") In a hundred years we'll all be dead. I don't think of it, of anything. I feel fairly well physically and mentally. I suppose anyone would prefer to be with his kin, but it's up to the authorities as to discharge. When it's time for it, it will come. There's nothing to do but sit around and wait and make baskets. I don't care particularly about basket making."

One day I called his attention to Irgocz squatting in a corner, eyes closed, and fingers to ears, and told him that was the end of the road he was traveling, a thing that could hardly be called a man, a mere vegetable, but it didn't jar him a bit. "He doesn't seem unhappy. If I get to be like him I suppose I shall still be patiently satisfied. ("Of what use will all your years of 
study be then?") I don't know, but I'm patiently satisfied. (Then with a gleam of pleasure): It is dramatic!"

In conversation his voice constantly tended to fade to a whisper. He now began to mutter to himself, but always stopped before anyone could get close enough to hear what he was saying. Another habit developed, of hawking and spitting. $\mathrm{He}$ would stand in the toilet doing this for an hour at a time. There seemed to be no phlegm, only saliva. Questioning about it irritated him greatly; it was the only subject that made him angry. "I'm sure I don't know why I do it. ("Think!") I don't think. ("You get nothing up, why do it?") For fun, I suppose. ("Do you think you have any disease?") I'm sure I don't know. You will have to ask the doctor."

Once I asked what he would do if he were discharged. "I'd shift for myself. I should have to readjust, buck up against the world. ("Would you rather stay here and be patiently satisfied or go out and buck the world?" He hemmed and hawed, evidently thinking he ought to say buck the world. "You really don't like to answer that question, do you?") No, I don't like to answer."

Occupational therapy: He consented to begin without urging and chose basket weaving, which he did beautifully. He wouldn't bother to learn any other kind of work, and subsequently admitted he had learned to weave baskets in another hospital. He became so expert that he could continue his fantasying as he worked. If he ran out of material or got stuck, he made no sign but sat thinking until the instructor noticed his idleness.

After a few weeks he lost what interest he had and began to beg off, saying he'd rather think or he didn't feel well.

He was very shy with the instructor, refusing to enter her small store closet with her. Only after she had come out would he go in. Once he wished to return a tool when she had both hands full, and when she told him to drop it into her apron pocket he became much embarrassed and laid it on the window sill.

Physical examination: Short in stature. Skin dry and covered with fine flaky scales. Beard very heavy. Hair, male 
type distribution, very extensive over chest and abdomen. Genitalia normal. Extremities cold and cyanotic. All superficial and deep reflexes markedly hyperactive, but movements are slow and deliberate, though with no suggestion of catatonia. Heart rather rapid.

\section{Endocrine diagnosis: Submyxedema.}

Glandular therapy: While he was fed desiccated thyroid gland, nurses and attendants thought he seemed more alert and energetic. He talked sensibly with the occupational therapist and even joked with her. For two weeks he stopped his spitting, then began again. He went outdoors on his own initiative and lay on a bench. When asked why he had never done so before, he said that this was the first weather warm enough to make it pleasant (April 30). He stopped whispering with me and teasingly complimented my personal appearance.

Four months later: $\mathrm{He}$ was still pouting out his lips and spending hours in spitting. When the male nurse tried to prevent the spitting he became very excited. He had shown distaste for food at times and talked of his mouth being dirty. He still kept by himself, smiling over his fantasies and doing no work.

Mental diagnosis: Simple schizophrenia without projection. $\mathrm{He}$ found the inner world of fantasy so far preferable to the outer world of reality that he spent most of his time in thought. Just what his most intimate fantasies were could only be surmised. He would not divulge them. It was clear that some of them were heterosexual. I suspected others were homosexual for several reasons; his fear of the topic of homosexuality, his interest in my physical appearance, and his statement that women didn't like him but men did. He showed no signs of conflict or struggle against improper wishes and he projected none of these onto his environment.

The only painful symptom of his psychosis was the mouth and throat obsession. There was much affect connected with it. It looked like a fellatio fantasy, a symbolic cleansing of the mouth and throat, such as Lady Macbeth's rubbing of her hands to cleanse them of the king's blood. The constantly pouted lips indicating oral eroticism supported this theory. 
Even his education was an autoerotic pleasure. He made little effort to apply it in a constructive way, but regarded it as a spiritual endowment to play with in egotistical isolation. In this autistic thinking his mind was as he said supreme. But that he had sometimes attempted a self-cure was shown by his taking for a model Benjamin Franklin, the man with both feet on the ground.

\section{BAILEY}

History: He was a thin, sallow fellow of thirty-three, the youngest of three children, and had been much indulged by his parents. He had always been sensitive, quiet and shut-in. In childhood he seemed bright and once skipped a grade at school. He stopped school at thirteen because a teacher unjustly accused him of throwing a spitball. He would not explain her mistake to her but absolutely refused to attend school any more. For the next three years he worked in the family grocery and then entered a machine shop. He apparently gave satisfaction to his employers, but if the family asked him any questions about his work he got very angry. He told me the work had been heavy there, and he wasn't strong.

At seventeen he quit work and lived at home for fifteen years, supported by his father. His relatives secured jobs for him, but he always backed out at the last moment. He worked only at chores about the house. His amusements were talking and playing cards with one boy friend, who has since become "queer." Movies and other outside amusements made no appeal to him. He had no use for money and refused it when offered. Home and meals were all he wanted. His family did not consider him sick, but they continued to indulge him.

After nine years of this life at home he had a "breakdown," and was confined to bed for two weeks during which he refused to eat. A physician was called and informed the family he was mentally sick. From this time on he did no work whatever about the home and gradually became untidy. He had to have his food just so, and insisted on preparing it himself. $\mathrm{He}$ wouldn't change his clothes or bathe and he let his hair grow long for a year and a half. The family brought barbers to the 
house, but he would not let them touch his head. He read a great deal, particularly the daily papers. Finally he became irritable, smashed dishes and threatened his father and sister. Very reluctantly the mother consented to his being sent to St. Elizabeths.

He submitted to being bathed and shorn without fuss, apparently realizing that opposition would be useless. He said he had worn his hair long and stuffed cotton in his ears as a protection against cold, and that he had come to the hospital because he had a cold. He didn't feel well physically but he was mentally well. The result of his mental examination was fairly good; it was evident that his failures were due to inattention. $\mathrm{He}$ resented personal questions and said such things were nobody's business. Whatever answers he made were brief and to the point. The family history showed no insanity in direct line, but two cousins were insane.

Sex life: He was very reticent on this subject and delicately conveyed his sentiments by interpolating that he did not like to pry into other people's affairs. He hinted he had had heterosexual experiences but that lack of money had hindered him. Night emissions he considered shameful, as bad as urinating in bed. His sister said he had masturbated a great deal.

Fantasies: He would not tell what his thoughts were, but said they were not unpleasant. However, he never smiled or showed signs of enjoying his fantasies like Abrams. Sometimes he muttered about not earning enough wages and having the family on his hands to support. He once told his sister he had supported her for years.

General observations: $\mathrm{He}$ spent nearly all his time sitting quietly in a chair or lying on a bed. There was no expression on his face either of pleasure or distress. He said he didn't feel sick, but weak. He did not believe there was anything the matter with his mind. "I have no worries, I just take each day as it comes. Sometimes I just rest and have no thoughts at all. I have no plans for the future, and no complaints. I feel bashful, and if there isn't any particular business to talk about I find it difficult to make conversation. When I read the papers the 
big print of advertisements naturally attracts me most. There is no particular kind of news that I am most interested in." These answers he gave very slowly after much waiting, and he seldom looked at me. During our interviews he almost constantly moved his forehead and scalp and the tops of his ears.

He seemed to be irritable towards his sister and sometimes was upset after her visits.

Occupational therapy: He refused all attempts to interest him, saying he felt tired.

Physical examination: Slender type of skeleton. Skin pale. Body surface presents scanty amount of hair. A few long hairs about the nipples. None over face. Genital hair of male type. Genitalia normal. Heart regular but shows incompetence of valves. Respiration increased. Extremities cold and bluish. Reflexes normal.

Endocrine diagnosis: Submyxedema.

Glandular therapy: He was given desiccated thyroid gland. Coincident with the first feeding he consented to try basket weaving which he was able to do well, and he continued to work without urging. He did not mutter to himself as much as before and he took part in the ward work on his own initiative. Formerly he did so only when ordered. He stopped lying on his bed in the day time, and seemed to pay more attention to what was going on around him although he kept strictly to himself.

Four months later: $\mathrm{He}$ seemed unchanged. He still muttered to himself, and felt resentful towards his family for depriving him of his liberty. He said he wanted to make money and be free. He would not go on excursions but preferred to hang about the ward.

Mental diagnosis: Simple schizophrenia without projection. Finding the demands of reality too hard he retired into himself and a life of thought. He carefully guarded the secrets of this inner life. Although he said his thoughts were not unpleasant he never betrayed any signs of pleasure. The only emotions he gave outward expression to were irritation and resentment, particularly towards his family. Probably they had at times reproached him for his useless life, and his delusion that he had sup- 
ported them was a protective device against the painful realization that he had done nothing but sponge off them for fifteen years. He gave up in early adolescence the struggle for a constructive life and retired into himself and the easy satisfactions of autoeroticism.

\section{CARHART}

History: He was a pleasant, courteous little fellow nearly twenty-one years old. He was the second of five children. The father was a musician. Nothing was known of the family history, but a photograph of the mother showed a woman with a tense, high-strung face. As a child he said he was active, playing first with hoops and carts, and later bicycling and playing baseball, football, tennis and swimming. He was very imaginative and loved fairy stories. He would imagine toys he did not possess and play with imaginary toy forts and soldiers. $\mathrm{He}$ wanted the things money would buy and envied the rich riding past in their automobiles.

He said he was happy as a schoolboy, got along well in school, and was considered a good fellow. He never failed to pass and finished the eighth grade at the age of fourteen. He wanted to continue into high school, but his father said he could not afford to support him any longer and got him a job as office boy. For two years he attended night business school. He was very ambitious to earn money. At the outbreak of the war he enlisted and saw service at the front in a machine gun unit. The horrors of battle, the noise and blood and death made a deep impression on him, but he did not break down under the strain. After the armistice he was sent to Coblenz in the army of occupation. He returned with his regiment to the United States in the summer of 1919 and was discharged from the service. The family had moved to Chicago during his absence. He rejoined them there and got a position as clerk in an office.

He didn't get on well in his work and suffered a great deal from "nervousness." His mind began to be "torn up, and he couldn't look people in the face." He became depressed and once stepped purposely in front of an approaching automobile, "but something seemed to pull him back." He entered a local 
hospital willingly. The records of the hospital stated that he was emotionally unstable, often depressed, disoriented for time, heard voices, smelled bad odors from his chest, thought his mind was changing and going up into the air, and had delusions of continual emissions of semen.

He was soon transferred to St. Elizabeths and was confined to bed after his arrival, confused, retarded, hallucinated, and complaining of headache and gastric upset. In a few days he was up and around, cheerful and fully oriented, but still hallucinated and suffering transitory excitements.

Sex life: He had a strong sex taboo and considered that such matters should be hushed up, but as he gained confidence in me he told me more and more, though he often became emotionally blocked and changed the subject abruptly.

When he was seven he tried to have intercourse with his one year older sister but was not able. There was another girl he wished to try it with but he was too bashful. He had always been very bashful and modest. He saw her brother smell of her genitals. He smelled of the "cheese" on his own glans penis and was disgusted at the fishy odor. He hated the smell of fish and never ate fish. He hated to look at a penis.

When he was eight he agreed to perform mutual fellatio with a playmate but the other boy backed out at the last moment. That wasn't fair (great emotion). His conscience had bothered him over this attempt. He denied having committed any perversion. ("Did you ever dream of committing one?") "Yes, a dream of a darky boy." Then a wave of emotion swept through him, he jumped to his feet, paced the floor, grabbed a magazine, and feverishly turned the pages to find anything to get his attention away from the painful memory. He was so upset that I had to terminate the interview.

$\mathrm{He}$ began masturbation before he reached puberty and had sometimes indulged in it excessively. When his will power was strong enough he resisted it. He used to worry over masturbation and night orgasms. At sixteen he tried coitus with a prostitute but could not get an orgasm. He made several more unsuccessful attempts before he went to war. In France he tried again twice and failed. Once he masturbated while still in the 
girl's presence and got an ejaculation. In his third attempt at coitus he got an orgasm but it was not as pleasurable as masturbation.

His mind dwelt a good deal on sex matters. He had heard of bestiality, and a buddy had described the sensations enjoyed when allowing fellatio to be done on oneself, which greatly stirred his imagination. He said that in Coblenz he had several times gotten an orgasm merely by willing it. He held strange theories over the predetermination of sex in embryos and believed in the existence of eunuchs, who had no sexual organs, and "morfudites," a creature who had the organs of both sexes and could hold intercourse with either sex or with itself. At times he talked of his heterosexual experiences with an exuberance of sensual enthusiasm, and at other times he expressed dissatisfaction over them and stated he was glad he had gone only with girls who made a business of it, and so had never ruined any girl's good name.

His sexual preoccupations persisted after his return home. $\mathrm{He}$ slept with a younger brother and often woke up to find himself on top of the boy with an erection, but he never committed pederasty on him, the brother "was too small." $\mathrm{He}$ fondled his fifteen-year-old sister and tickled her nipples. Fear of his father prevented his attempting incest. With great satisfaction he said he knew his sister loved him very much, and then asked me if a girl that young could have a baby. If he had made her pregnant he would have married her, of course. When I told him the law would not allow them to marry, he became very angry, said it was the only decent thing to do in such an eventuality and that some things were higher than the law.

After having an orgasm from will power he went up almost into "Morphia," it felt like dying. Sometimes it felt like going up into the air (an interesting corroboration of the theory that dreams of flying have a sexual meaning). He would hear a girl's voice from a distance asking if he wanted coitus, and then she would "bull" him, that is, cause his semen to go off. It felt like going to heaven. He too had the power of bulling. By nodding his head he could break another man's neck without 
touching him. That was a headbull. He himself was a bullprick; once in a street car he bulled the other passengers, men and women, till they nearly had orgasms. Then he got scared and feared they might see something queer in him.

In another talk he showed insight and volunteered that these bull incidents might have been only imagination. "My thoughts are lewd. I have a lot of fear, I don't know what of. I'm like this" (making a gesture indicating vacillation and instability). The fear was evident. He had a constant fine tremor and when spoken to suddenly or told that someone wished to see him, he would tremble visibly.

Fantasies: Thoughts both pleasant and distressing intruded constantly into his mind. Our talks were badly interrupted by these excursions into fantasy. When they were agreeable he smiled or even laughed aloud, but when they met resistance he became frightened and excited, often pacing the floor and trying desperately to find something to divert his attention from the painful subjects. This explains his statement, "When I'm in motion, it takes away the fear. Fear is caused by what other people think of me or want to do to me. I called on the Maker to remove the fear."

The Maker was the All-powerful, the Creator of all. This idea was of great emotional importance to him. He took Maker for his middle name, calling himself John Maker Carhart, and every letter home began with the set phrase, "Just a few lines to hope you are in the way of the Maker, and well, and happy." Every day he wrote a letter to each of his parents. This preoccupation with the Creator looked like an attempt to sublimate his creative libido in religion.

As a child he had many fear dreams. One was of running down a street with fear coming down out of the sky; the world seemed to be coming to an end. Others were of falling off high places. Recent fear dreams were of men shooting him below the umbilicus. The night nurse said he trembled in bed as if having a chill, pinched himself and hunted in his clothes as if looking for bugs or lice. In the daytime he grabbed at his trousers and said there were snakes in them. 
He believed in reincarnations and said he had been living two billion years and his father had lived fourteen hundred years. $\mathrm{He}$ could not remember his former lives. At death he went into his mother and was reborn a baby, but this time he had asked the Maker for manhood. If he were killed now, the world would come to an end. He feared the doctors were going to injure him. In one of his former lives he was Pharaoh. A snake bit him below the umbilicus and killed him. He had a vision of a house smeared with blood, snake blood, and it was connected with fear. Another vision was of a lighted candle several feet high coming up through the floor. (Symbol of the big potent penis. Some prostitutes had told him his penis was too small.)

He could hear the voice of his father or his first employer. Sometimes it was the Maker giving him hints. These voices seemed to be in his head, just like one's conscience. He thought it might be possible to throw one's voice from one city to another, but he wasn't sure and couldn't prove it.

He was beginning to believe he had two sets of parents, one pair tender and loving were back in the old home town, and the other pair harsh and unsympathetic were the ones in Chicago. $\mathrm{He}$ wanted to revisit both cities and clear up the mystery, then he would travel all over the world and bring about equality, brotherhood and happiness. As a boy he had great ambitions, he had chased the rainbow and wanted to be a big man.

While still in Chicago he had pulled the sun over the horizon several mornings. That gave him a manly sense of power. On the way to Washington the sun had been attached by a cord to the back of his head and was towed behind the train. The back of his head had burned and felt as if wheels were revolving in it, and he had suffered much. He had fallen in love with the pretty nurse in the receiving ward, and his heart grew big and extended way down into his abdomen.

His father was a magician and had purple eyes. Some day he would be one and have purple eyes too. Since being in the hospital he had grown very fond of purple. He had "a beautiful dream of a castle all purple against a blue sky. That was happiness." 
His mother and little brother were angels, and his sister was Jewish and owned Jerusalem. Often he grabbed his nose to feel of it, saying it felt as if it were being drawn into a Jewish shape. He strongly resisted divulging what significance Jews had for him. All I could learn was that one of the men in the office in which he first worked was a Jew and told many smutty stories.

General observations: In the first interview it was apparent that he was trying to fight off unpleasant ideas. The subjects that seemed to excite and upset him most were sex, his boyhood, the Maker, and his little brother. He said he loved his little brother, that the little fellow was sad and he wanted to comfort him, then he got very excited and rushed to look out a window.

He talked much about not wanting to hurt people's feelings and said perhaps he had done so but not enough to kill them outright. $\mathrm{He}$ was excessively polite and anxious not to give offense, and went about the ward shaking hands with each patient. He said he didn't want hard feelings with anybody and that he always tried to make up.

He had partial insight into his condition. He considered he had just passed through a "period" between youth and manhood, and was now safely through it and should be discharged. He refused to be treated by any physician but would talk with the analyst because "we're friendly." $\mathrm{He}$ was well and ought not to be locked up like a criminal, especially after all his services to his country (much emotion). He described the horrors of the front, the noise, the maiming, the blood, and the danger of death. Noises bothered him greatly now because they recalled the sounds of the front. He hoped some day he would be able to think of these experiences without pain. The horrible sights had changed him. He used to be effeminate and sensitive but the war had made a man of him. It was the strain of life at the front that had made him "unnatural," and he had remained that way until he became naturai in the receiving ward a few weeks previous. It was not his being in the hospital that had made him natural. It would have happened anywhere for the period was over, that was all. $\mathrm{He}$ felt very bitter at the doctors for refusing to allow him to go home. It was just awful for people to oppose his will. 
He was reticent about making me his confidant, saying it took him a long time to decide who was a friend, but that once accepted as a friend, always a friend. He told about his family and how united they were. If he should marry he would bring his wife to his parents' home, he couldn't be separated from them. Or better still, her parents would come also, and they would all live together. He called his parents daddy and mama. In the army he learned to call them father and mother, but now he preferred to use the old names again. I told him the story of Oedipus, and he was intensely interested, but when I went on to narcissism, bisexuality and homosexuality he jumped to his feet, and said he must leave the office, he wanted to lie down and sleep. This was his usual reaction to any attempt to discuss these painful subjects.

$\mathrm{He}$ behaved so well that he was given parole of the grounds. One day, however, he demanded to see the superintendent about being discharged, and when told the latter was not in his office he became excited and created something of a scene in the administration building. His physician took away his parole, and he became very despondent. "My confidence has been broken by being kept here like in prison. I don't want to spend my life here. It's a shame. I give up now. After what I did for my country this is the treatment I get." He grew rather careless in dress and left off his collar. He was warned that his physician would regard untidiness as a sign he was getting sicker, and he put the collar back on.

Through promise of good behavior his parole was restored. He said if he should go home now he would go out in the woods and die. The hobo life attracted him. He hadn't known the world could be so harsh and cruel. He refused to acknowledge he was sick and would not become reconciled to waiting until the physicians considered him cured. He began to withdraw more into himself. The night nurse reported he cried a good deal in bed. He refused to join in the occupational work any longer, and said the doctors didn't know anything. One evening he broke parole and went to town. He had no money but got a night's lodging in a mission and saw the sights of the city the 
next day. Then he asked a policeman to help him get to Chicago, but instead the policeman helped him back to St. Elizabeths. His parole was again taken up and he was transferred to a less desirable ward. While out walking with his new wardmates he made a dash to get away but was captured by an attendant.

Once I succeeded in getting him to tell of his experiences in France, which he remembered and related well, but when $I$ began talking about psychology and mental conflicts he got resistive and distrait and demanded to go.

$\mathrm{He}$ resisted the sugar tolerance test because it smacked of medical treatment, and he was maintaining that he was perfectly well and was being unjustly deprived of his liberty. The venal puncture so unnerved him that he nearly fainted. He resented the removal of blood from his body because that weakened it. $\mathrm{He}$ disapproved of all killing and would eat nothing that had been killed. This was a result of his horror of war. As a consequence his diet was much restricted and he complained of not getting enough to eat. He nearly cut out milk also, but fortunately it was possible to convince him that it was kinder to milk a cow than to leave her unmilked.

Although he was friendly towards me and said he felt better after talking things over with me, he would not face his conflicts and discuss them.

During the examination after his arrival at the hospital it was noticed that when painful subjects were touched on he moved his lips and ran his tongue around behind them. In my office his hands were held pressed over his genitals much of the time.

Occupational therapy: It was difficult to hold his interest. He got discouraged at the least obstacle and quit, saying he didn't feel well or didn't like to work. He never finished anything.

Physical examination: Small type of skeleton. Skin poorly nourished with several scaly lesions on face, neck and back. Slight amount of hair in mid-sternal region, and submasculine type in genital region. Genitalia normal. Heart rapid. Extremities cold and cyanotic. Reflexes sluggish. Slight tremor of hands.

Endocrine diagnosis: Submyxedema. 
Glandular therapy: None. He refused to take anything resembling medicine. Coaxing and argument were in vain. $\mathrm{He}$ would not take medicine because he was not sick.

Four months later: I found him sitting alone in a washroom. $\mathrm{He}$ remembered me at once, called me by name and seemed friendly. He was much more introverted and was lost in his own thoughts most of the time I tried to talk with him. He showed none of the former desire to get out of the hospital and no longer wrote home. The records stated he said he liked the hospital and was not anxious to leave. No mental conflict was in evidence, he seemed just calmly lost in thought.

Mental diagnosis: Schizophrenia with projection. His mind was split, part of it living in fantasy. He consciously resisted homosexual cravings and also projected them unconsciously, as shown by his saying that fear came from what other people thought of him and wanted to do to him.

In his regression he returned to his boyhood habit of imagining and called his parents by the names of childhood. He found reality too harsh and cruel. The fact that he was held virtually a prisoner in the hospital he found too painful to face, so he repressed this knowledge, considered himself a voluntary guest and repeatedly asked for a ring of keys. Reiterated explanations why a patient could not have keys made no impression whatever, and within a few minutes he would courteously ask for them again with calm assurance.

The sister incest wish was conscious. If there were mother incest wishes also, he either hid them or repressed them. Probably it was resistance to incest that rendered him impotent in his attempts at heterosexual intercourse. The idea of reëntering the mother to be reborn is connected with the idea of incestuous intercourse. His resistance was shown in his asking the Maker to grant him manhood and stop the rebirths.

The snakes which bit him and pistols which shot him near the genital region were penis symbols in his projection of the impulse to take the feminine rôle in homosexual acts. He often showed great excitement when these ideas forced their way into consciousness and he would not discuss them with me. Any 
approach I made towards them resulted in mental panic and flight. Consequently psychoanalytic treatment was powerless to help him. At first I had had hopes of a cure. Perhaps if he had consented to taking desiccated thyroid it would have stimulated him to such a degree that he could have suppressed the perverse cravings sufficiently to be willing to recognize them and talk of them, and then psychoanalysis could have been used.

$\mathrm{He}$ is now introverting more and more. Already the realm of fantasy has so far displaced reality that he is largely indifferent to whether he remains in the hospital or not.

\section{Dixon}

History: $\mathrm{He}$ was a tall, thin, weak-looking fellow with a long, very narrow head and a high-arched palate. His age was twenty-nine, and he was the youngest of four children. The father died of pulmonary tuberculosis when the patient was seven years old. He surmised there hadn't been much love between the parents. The father criticized the mother for being too affectionate towards the oldest son. This older brother used to beat the patient a great deal.

He went to school until fourteen but had reached only the fourth grade. He had difficulty in applying himself to his studies. He didn't care much for rough and tumble games with other boys. For two years after leaving school he worked as a tabulator of weights in a coal yard but wasn't successful. At sixteen he entered the army, didn't like it and bought a discharge. Next he tried the marine corps and was given a medical discharge after three months' service.

From seventeen to twenty-six years of age he led a roving, unsuccessful life, wandering from job to job over all the eastern portion of the country from Chicago and New York to Florida. $\mathrm{He}$ worked usually as waiter or dishwasher in cheap restaurants or in the galley of ocean ships for single voyages.

Early in the war he was drafted, and within two months was in France and served as a cook in a camp far from the front. Less than three months later he was in hospital on suspicion of appendicitis (these pains in the abdomen have persisted and may 
be connected with the idea of pregnancy). No operation was performed and he was returned to the United States as a psychopathic patient. Four months after his entering the hospital in France he was discharged from Saint Elizabeths as recovered from an undifferentiated psychosis.

He went home and tried one job after another but could not give satisfaction. He lost them all and became very much worried. He was returned unprotesting to this hospital after only ten months' liberty.

On readmission he complained of fatigue and said he felt weak and nervous and that his mind was weak and he couldn't concentrate on anything. He heard voices and felt he was being imposed upon but that there was nothing much the matter with him personally. He was fully oriented, his memory was good, and he did fairly well in the intelligence tests.

Sex life: He remembered, when he was eight years old, seeing boys at school masturbate behind their desks and afterwards smell their hands. At ten he started the practice himself and indulged almost daily although he considered it immoral. After puberty he began having intercourse with prostitutes and liked this better than masturbation. Sometimes he could not get an erection and the girls laughed at him. He noticed that he nearly always was impotent if he tried to have intercourse twice with the same girl. He had to seek a new one. To overcome his impotence he once bought an expensive "vitality belt." $\mathrm{He}$ felt bashful with girls.

He denied having committed any perversions and felt disgust for them. He could hardly believe a person could so lower himself, yet twice men had offered him money to be allowed to commit fellatio on him. "I refused. It was an awful risk. I feared their teeth. It may have been done to me in my sleep but never to my knowledge. I really am afraid to go asleep and I try to keep one eye open." On shipboard erotic members of the crew had grabbed him and hugged him but he had fought them off. Often he had dieted and taken medicine to reduce his sexual cravings.

"I object to hugging and kissing for it may stir up my body, my passion. I don't like my mother or sister to kiss me. Mother 
kisses me on the cheek. It makes her sick when I go home, she worries over me. She isn't good to me. She told me once she wished I was dead. I wouldn't care to live with Mother unless I was married. I wouldn't sleep with my wife if I had one. It would tempt us to do it too often. The body ought to rest. My sister's husband forbid me to come to their house unless he was there, but I never thought of her body. I let her kiss me but I don't believe in it."

For four years he had had no coitus and since being in the hospital no erections. There were occasional night orgasms but he could recall no accompanying dreams. He had felt no sexual passion, and tried to keep his thoughts off such subjects.

Fantasies: His first complaint was that people paid too much attention to him. They thought the same things he did. While he was reading he could hear a voice in his right ear saying the words out loud. Probably it was somebody in another room reading through his eyes. He couldn't keep any secrets. Other people were reading his mind always, everywhere. This "influence" was always working on him, something like hypnotizing. He was never free from it. He resisted it, but he was forced to give an account of everything he did, where he did it, and when. Nothing could be hidden. He had to commune to some power everything he had done. Something was sucking his mind, it wandered off and he couldn't concentrate.

"It seems as if I was an old whore. They can see through my eyes. My soul is so weak that it is exposed. A whore's soul is exposed. After taking a walk I think it over three or four times and see it again, not of my own free will but because I am forced to. If I hear anyone giggle or laugh I think it is at me."

Voices talked to him of taking both the male and female rôles in fellatio, pederasty and coitus inter femora and of cutting off his penis. They both urged him to ask other people to commit perversions with him and accused him of having committed them. "When the nurse comes near me the voice tells me to order her to commit fellatio on me. I've heard a voice commanding me to say that three times since I've been talking to you. When you approached me a voice urged me to say, 'Doctor, you look 
good to me.' ("Have you ever realized that these voices might be your own thoughts?") No, I never think such things or pay attention to people's bodies. It seems very degrading and immoral to me, like the firemen hugging me on board ship. Just now the voice tried to get me to call you a fellationist. It says I'm guilty of fellatio, and yet I haven't really done it.

"That fellow, Carhart, seems to influence me to ask some fellow to commit pederasty on me. I'm afraid to go to sleep for fear someone might do it to me. My abdomen feels dead and it pains and is all swollen. I suspect three or four men, the attendant and Garland and Mathews. ( $\mathrm{He}$ told another patient that I had told him he had a baby inside him. This may explain the pains that were first diagnosed as appendicitis in France.) They try to make my left eye bigger than my right. The voices sometimes tell me not to eat anything, and then if I do start eating my mind goes blank (emotional blocking from resistance to fellatio ideas?). I'm a light eater, chiefly bread and coffee. I vomit fish and greasy things. (Recall Carhart's aversion to fish.)

"I've had wet dreams of seeing dogs at intercourse. ("Male or female?") Well, perhaps two males, just like you see in the street when they jump each other. You seldom see a male and female doing it, it's usually two males. Yesterday when I was walking near the edge of the grounds a negro grabbed me fearing I was trying to escape. My first thought was that he was a fellationist. I dreamed recently of being at an auction sale of bunches of green bananas. Mother seemed to be there to buy them, though I couldn't see her.

"My mind can't be at rest. The patients are too near me. They have sucked everything I know out of my mind, all I've been through in my younger days and recently, and now I'm at their mercy. It seems as if other fellows make me a scapegoat for their wrong deeds. They run their minds on me, put ideas into my head like hypnotists. On the Red Cross excursion I was embarrassed and had to hold my head down. I can't keep my mind on anything, but just sit and play like a child."

General observations: The constant intrusion of unwelcome sexual thoughts kept him worried and unhappy. His face was 
puckered and furrowed with anxiety on account of this continual "influence." He was irritable and unsocial and didn't like to work. Most of his time was spent in wandering miserably around the institution. He couldn't enjoy himself in the Red Cross recreation rooms because the other patients kept digging into his mind.

I often attempted to explain to him mental mechanisms such as repression and projection, but he vigorously rejected the explanation that his woes might come from his own unconscious mind. My talks made not the slightest impression on him.

He said he often found his hands crossed over his genitals or his thumb or finger in his mouth, but of course it was "influence" that made him do this.

Occupational therapy: He took to the work without urging, did fairly well and seemed to enjoy it, then got more worried and resistive and refused to work saying, "I can't do it, I don't feel well," and making other excuses. He had parole of the grounds and preferred to go outdoors rather than do handiwork in the ward.

Physical examination: Tall, slender type of skeleton. Head elongated. Slight amount of hair over body. Genital hair and genitalia normal. Perspires easily. Heart normal. Moderate tremor of fingers. Reflexes sluggish. Pulmonary tuberculosis is suspected.

\section{Endocrine diagnosis: Submyxedema.}

Glandular therapy: Thyroid was first given and seemed to make him very irritable. He had been peaceable previously, but now he quarreled with the attendant and complained of him for being noisy and bossy. "It's been harder to keep my mind on things today. I feel like throwing my food on the floor. I don't enjoy nothing." The nurse reported him as restless and more talkative than usual. The thyroid stimulation seemed only to increase his difficulties.

A combination of thyroid and orchic was next tried and proved beneficial. He lost the "influence" for half an hour at a time, and during these welcome interludes his mind felt free of all outside control. He said he felt better physically, and his appetite im- 
proved. He voluntarily joined in the work of the ward and soon was making all the beds. His facial expression looked somewhat less worried.

Four months later: I found him lying on his face on the corridor floor. When I roused him he recognized me at once. He said he was much bothered in mind. He had given up going to town on theater parties for he couldn't keep his mind on the play, nor could he concentrate enough to do occupational work.

Mental diagnosis: Schizophrenia with projection. All his improper sexual cravings were projected onto other people or on voices. He had no insight whatever and resisted any explanation. His resistance to kissing his mother and sister clearly indicated incestuous impulses as did also the dream connecting his mother with green bananas (immature or stiff penises?). Probably this incest resistance was what rendered him impotent towards a woman after once he had intercourse with her and she had become familiar. Being thus hindered in getting his libido over to the other sex, his homosexual cravings became very strong. $\mathrm{He}$ did not succumb to them but protected himself through disgust. Not being able to repress the cravings and too horrified to recognize them as his own, he was forced to project them. His recent sexual impotence was probably a defense against the perverse cravings. At night he still had orgasms but the dreams were repressed. In the former wet dreams of the two playing dogs the real meaning was sufficiently disguised. Now the meaning of his wet dreams was probably too apparent to allow them to be recalled. He accepted dreams as products of his own mind and did not blame them on outside influence.

The continual influence came of course from his unconscious. During glandular feeding he was able to completely repress his unconscious thinking for brief periods, but with total lack of insight. After the feeding was stopped the repressed thinking became too strong once more. Except for his inability to repress the obnoxious cravings and the splitting of consciousness which resulted, his mind did not seem deteriorated. He was perfectly oriented, his memory was good, and he could talk intelligently. 


\section{ENGEL}

History: He was a man thirty-nine years old and mentally deteriorated. It was difficult to get him to tell of his past life, and the medical records were brief. His boyhood and youth were spent in a great city, where he received a fair education. After leaving school at fifteen he loafed at home for several years and then worked in a tailor shop and a piano factory. At the age of twenty-two he entered the army and was an officer in the Philippine Guards when taken sick ten years later. He married at twenty-nine but had no children. His father died of alcoholism and his mother of tuberculosis. He himself never drank to excess.

His wife said he overworked in the Philippines and had a breakdown lasting a month during which he had fearful dreams, one being that he had killed her. Two years after this illness he grew depressed and anxious and felt unworthy. One day at table he rushed out of the dining room greatly excited, saying he was choking and and his throat felt sticky. He was afraid she had left him and married another man. Voices accused him of disgracing himself and called him a thief and coward and other bad names. He feared he might die or be killed, and made one half-hearted attempt at suicide.

After reaching St. Elizabeths he was suspicious and had unsystematized delusions of persecution. A twitching tic of the mouth was noticed, and sometimes he kept his tongue protruding. $\mathrm{He}$ said he was bad and had wronged his wife, and the police were after him. He stuffed his ears so as not to hear the persecuting voices, and complained of peculiar sensations in his head and of frontal headaches after the sticky feeling in his throat and the resultant choking.

Sex life: In answer to my question what was his chief pleasure as a boy he said, "Playing with myself, jerking off." He added that when he was twelve or thirteen years old a servant girl of thirty-five gave him all the coitus he wanted. After her he had relations "with a lady, nice and clean." No further information could be obtained.

Fantasies: He had a great habit of scolding at nobody in particular. During one of these tirades I asked what bothered 
him. He answered, "A man wanted to marry me. He called me good looking. He was stronger that I. You look like the man who wanted to marry me."

On another occasion he indignantly complained that these pimps around here called him a fellationist. A fellow patient told me he sometimes acted as if someone were after him and exclaimed, "I don't care for any old man or anybody who bothers me and does things of that kind."

He said he either dreamed of nasty sexual acts or of money with which he would buy lots of clothes and things.

General observations: His most striking feature was a strange, persistent smile, mostly in the eyes, as perplexing as that of Monna Lisa. It could change very quickly into an expression of frank hostility, and at first I was careful when near him, but he never offered violence to anybody. I believe the smile denoted uncertainty and suspicion of other people and an attempt to discern their sentiments.

A conversation with him was next to impossible. He looked at one most of the time with this impenetrable smile, and though he started many sentences seldom finished one; they usually stopped part way before the meaning became evident. One day I felt that he was trying to divulge something important and was on the edge of doing so several times but couldn't quite decide to take the plunge. He had used the phrase "nice and clean" again and again, "live nice and clean," etc. I suddenly asked, "What about dirty?" "That's all the trouble," he replied, "I don't think I ought to live on. I've been sort of married to everybody. I felt dopy and sleepy in the Philippines. Now I feel that way too, sometimes. Nice and clean, independent, nothing annoys me much, live on nice and clean. I get along pretty well." He was very careless of his clothes and often went about with fly unbuttoned and genitals half visible. ("Why do you do that?") "They ought to look at it." He said fellatio, pederasty and masturbation were all dirty, but heterosexual intercourse was clean. This information was slowly and laboriously extracted from him in piecemeal fashion. 
He usually knew the date, said this was an insane asylum and knew how long he had been here, but he didn't know people's names or positions.

Occupational therapy: He could play casino, but forgot his turn or played ahead of turn. He couldn't seem to learn basket weaving, and did poor work because he was unable to concentrate. He could catch a ball even when thrown at him suddenly in a tricky way. His greatest delight was to take a pencil and cover a sheet of paper with numbers (he had worked as a commissary in the army). Sometimes he wrote sentences such as "Please acknowledge I am a deserter" or "The best thing a man can do is to keep clean and be respectable."

Physical examination: Medium type of skeleton. Skin scaly. Hair dry and fragile. Beard scanty. Genital hair normal. Genitalia normal. Abdomen protuberant. Heart rate slow. Pupillary excursions limited. Reflexes hyperactive.

Endocrine diagnosis: Submyxedema.

Glandular therapy: Desiccated thyroid gland made him much more irritable and somewhat more active. His wife said he talked more freely to her than for years. In the ward he several times went into the worst fits of storming and scolding we had yet seen. He said he heard lots of voices all the time. While formerly he had to be undressed before a bath because if left to himself he would stop and go off into his thoughts, he now undressed and bathed himself without urging. He seemed to grow more uneasy and to fear I was investigating and trying to fix some crime on him.

Four months later: He appeared the same as before glandular feeding was tried. The summer records stated he had had delusions of grandeur and of electricity playing on him. He showed no such symptoms while in the endocrine ward.

Mental diagnosis: Schizophrenia with projection. His troubles were pretty evident. He had a tic of the lips and tongue, voices called him a fellationist, and at the outbreak of the psychosis he had choked and his throat felt sticky. Other men wanted to marry him, and he angrily resisted their advances. Dirtiness was "all the trouble," and his main idea in life was to 
keep nice and clean and be respectable. He explained that normal coitus was clean and perversions and masturbation dirty. Probably he had committed fellatio in the past and this was why his throat felt sticky. His strong homosexual cravings were vigorously resisted, and the fight still goes on. The feeling of sexual unworthiness probably antedated such delusions as being a thief and deserter.

\section{Foster}

History: He was a deteriorated patient who had been in the hospital nine years. His age was thirty-five. There was no history of nervous or mental disorders in the family except that two paternal cousins were insane. His father was of "primitive mentality." The patient was the youngest of seven children and was considered delicate and backward as a boy. He didn't do well in school and had to be forced to attend. He was always seclusive and quiet and disliked games and amusements. $\mathrm{He}$ showed such aversion to girls that he was teased about it. After leaving school he worked as delivery boy in his father's grocery, for which he received five dollars a week and maintenance.

Some weeks previous to his commitment he had complained of severe headache with loss of appetite and vomiting, and later became retarded and stopped work. He acted frightened, wept, said he was "full of electricity" and blamed himself as "the cause of it all." In the hospital he continued to show fear and to blame himself, and remained in a semi-stupor. He would eat only when threatened with tube-feeding. One day after a bath he had a clonic convulsion lasting several minutes. He made several attacks on other patients "because they called him bad names." He was confused and weepy for three years, then became oriented for place and person and emotionally indifferent. He talked to voices, but said they didn't bother him. He never associated with other patients and never worked.

Sex life: All that the records stated was that he disliked girls.

Fantasies: He frequently laughed and, when asked why, answered that some certain person in the environment was the funniest looking one he ever saw. The individuals he pointed out had nothing unusual about them. It was evident that these 
replies were only excuses to hide the real cause of his pleasure.

General observations: $\mathrm{He}$ was untidy and tore his clothes. He would not wear suspenders and had to hold up his trousers with one hand when walking. He never spoke unless spoken to, and would if possible move away without answering. He whistled a good deal, learning the latest airs from the graphophone, and he liked to look at pictures, but never read.

The attendant noticed that when out walking he would respond to greetings from a distance but as soon as a person approached him he became uncomfortable, looked in another direction and tried to get away.

Occupational therapy: He turned his back on the instructor and paid no attention to her efforts to interest him.

Physical examination: Skeleton out of proportion with small pelvis and heavy upper extremities. Skin dry and covered with scabs. Hair dry and scaly and very fragile. Beard scanty. Genital hair normal. Genitalia normal. Heart slow. Circulation sluggish. Extremities cold and cyanotic. Patellar reflexes exaggerated. Gait shambling.

Endocrine diagnosis: Submyxedema.

Glandular therapy: The thyroid test caused him to become considerably more extroverted. He answered more readily when spoken to, didn't try to get away as much as formerly, noticed other patients, put on a bizarre skull cap belonging to the attendant and joined heartily in the resultant laughter, complained of pains and aches while formerly he never mentioned how he felt, and even consented after some urging to try basket-weaving. $\mathrm{He}$ also became tidier with his clothes.

Later a combination of thyroid and suprarenal was given him. The improvement was maintained.

Four months later: He seemed to have returned to his condition previous to glandular stimulation.

Mental diagnosis: Schizophrenia, with projection in the beginning at least. The meager records of his disease tally in the main points with the usual schizophrenia. He never got his libifo over to the opposite sex, and he had a sense of unworthiness and sin due, no doubt, to perverse cravings. Perhaps at first he had insight, for he claimed he was to blame for it all. After three 
years he apparently ceased the struggle against his unworthy tendencies and began to indulge them in fantasy, for the voices no longer annoyed him and he became contented. His laughter was probably over his formerly resisted fancies now freely indulged and not at the unlikely external objects he cited in excuse.

\section{GARLAND}

History: He was so deteriorated that he could not give any of his history. The following facts were selected from the hospital records. The family history was negative. He attended school till he was fourteen, and failed towards the end in the sixth and seventh grades. His longest job was in an optical shop where he ground lenses for seven years at low wages. At the age of twenty-four he married. He was extremely jealous and suspicious of his wife, and finally began accusing her of having sexual relations with almost every man in the neigborhood. He lost his job in the optical shop because he continually quit work early to spy on her. He heard voices call him vile names and feared his brother-in-law wanted to kill him. After losing the optical job he worked as elevator man and park laborer until he was committed at the age of twenty-nine. His wife had not lived with him for two years previous.

The above information came from the family. His own version at the time of commitment was that noises, like buzzing bugs or jumbled voices as if several people were speaking at once, annoyed him and kept him awake. Sometimes he could distinguish what they said, and it was both pleasant and unpleasant. Some told him to do right and others called him bad names. He could carry on conversations with them. He had seen unnatural things, but wouldn't say what. He believed his wife's mother poisoned his food. He felt discontented and was easily angered, but didn't understand why he was sent to an insane hospital, for he wasn't insane. The examiner commented that he was much absorbed in his own thoughts, and was restless and suspicious. He had no insight.

During his nine-year stay in the hospital he had gradually deteriorated. He didn't associate with other patients but had no 
difficulties with them. The voices kept bothering him, however, and he often answered them angrily and was "profane and vulgar." Shortly before entering our ward he complained that magnetic power was being used on him.

Sex life: The record stated nothing beyond that he was married, suspected his wife of infidelity, and denied venereal disease and perversions.

Fantasies: In our very first talk he brought up the subject that troubled him most. "A man isn't responsible when influence is used on him. I don't see why they use influence on me. I see myself turned over and shot upside down out the window and then come back again into the room, and yet I'm standing still in one place all the time. All day long they turn me over. They've no right to. It's an offense to the law to turn a man over. And I'm a married man. Action on the human body is an offense. They shouldn't go beyond the limit, beyond the law." This was his greatest annoyance, and his good days were those in which he said he was not turned over so much.

"Voices say things, thousands of them. I understand them, but I don't know where they come from. I can't use influence back again but I can answer. I enjoy their talks. ("Do they ever say bad names?" He frowns angrily.) I don't approve of that."

He had many face and head tics. He nodded his head violently up and down, his eyelids winked, and his lips smacked loudly. Often in place of smacking he would roll out a long neologism, "glahba-glahba-glahba-glah." $\mathrm{He}$ indulged in these simultaneous tics and exclamations only when angry and disturbed by his hallucinations and delusions. When they were agreeable he laughed in glee. The laughter occurred mostly when looking at pictures of women. This was one of his chief delights. He poured over Sunday supplements and magazines, cut out such pictures, carried them around with him, kissed them and took them to bed with him. The attendant once had to rescue his photograph of his fiancee. The patient said, "Pictures talk to me like any human being, not out loud, but influence. Not as plain as a voice like you, but still I understand what they 
say. No particular subjects, just matters of friendship and love." (Blushes-emotion.)

One night he took to bed a newspaper photograph of a noted prima donna who was suing for divorce. The following morning he told me she had spent the night with him in sexual intercourse, that she was going to settle a hundred thousand dollars on him, and he would marry her as the Earl of Wellington. On another occasion the attendant, out of curiosity to see his reaction, offered to bring a real woman to him. He became panic stricken at once and angrily forbade the attendant to do so.

At night he was very disturbed and often haf regular battles with imaginary antagonists. I sometimes came into the ward quietly and listened to him without his knowing it. He seemed usually to be fighting off another person or resisting masturbation. At intervals he exclaimed, "No, don't do that. Put your hand down. A nice young man like you," and his voice broke as if weeping. A "glahba-glah" would be interjected from time to time. After an hour's conflict he gave in and masturbated angrily, then became quiet. Patients in neighboring beds told me that during these struggles he talked of coitus, bestiality, cunnilingus and analingus. He would shout, "Take that man out of here. I don't want you. Come back in here." Then he'd leap out of bed and fight the air with his fists. The struggles ended in angry masturbation. Once he pounded his jaw as if angry at himself.

He complained somewhat of trees, saying that trees and cars did it, made the offense (turning him over), and that plants and trees annoyed him by talking to him, and he could feel their talk tap him on the abdomen like a person's finger (homosexual assault?).

"That gets me," he exclaimed indignantly, "I get the boys all the time and I want the girls sometimes."

General observations: He was a pleasant, friendly fellow quite willing to talk unless too badly annoyed by his hallucinations, but it was often hard to understand him, for he had given meanings of his own to familiar words and thus invented almost another language. For instance he would rub a forefinger in the palm of the other hand and talk about "material" and "ingredi- 
ents." This was constantly repeated, but I could never discover the hidden meaning.

The following is a typical conversation: ("What made you sick in the first place?") "It might have been actual sexual intercourse at a distance. It might be action. A married man. Sexual intercourse at a distance. I can't state just the reasons for it. I never had difficulties at a distance. It seemed to be action, that's all. Action is movement. From a distance to my penis. I never had any difficulties. While I was at work elderly men more than young men bothered me. An affliction. If he wasn't married, it wouldn't be action against him."

When not constantly stimulated by other people he was liable to go off into his fantasies, which were usually unpleasant, and then begin his violent tics and glahba-glah-ing or smacking. $\mathrm{He}$ could play casino but went into these tics while waiting his turn to play. He liked to join the other patients in playing catch with a baseball, and was quick and skilful, but lapsed into his mannerisms if the ball were not thrown to him frequently enough. When the others heard him begin to glahba-glah they threw a basket ball at his head, and he would laugh and join the game again.

A few times he made sexual advances to the nurses. But his great preoccupation was masturbating. Several times a day he would retire into the watercloset and indulge in it in spite of attendants and fellow patients.

Occupational therapy: He could not learn the simplest weave in basket making and spent fruitless weeks on a stocking cap. $\mathrm{He}$ would continually lapse into fantasy and weave blindly. Every day the instructor made him do some simple task such as marking holes on tray bottoms. He could play a game of cards because the other players continually called him out of his fantasy.

Physical examination: Slender type of skeleton, well nourished and muscled. Skin presents slight actiniform lesion. Beard slight, small amount of hair over abdomen. Genital hair normal. Very large genitalia. Extremities cold and cyanotic with dermatographism present. Heart normal. Extensive reflex excursions.

Endocrine diagnosis: Submyxedema. 
Glandular therapy: During the thyroid feeding he seemed to improve. He grew quieter because not so much bothered by his hallucinations. The masturbating nearly ceased. His mother visited him and thought him improved both mentally and physically.

Four months later: He knew me at once. His condition seemed the same as before thyroid feeding was begun.

Mental diagnosis: Schizophrenia with projection. His struggle against his perverse cravings was plain to see. Apparently they were all projected and he was not consciously tempted. At night, however, in a hypnogogic state, they sometimes broke through, and he cried that he would not do these things but wished he could.

His extreme jealousy of his wife indicates that he must have been impotent. The obsession of being turned over is probably a passive pederasty fantasy. Unlike some of the other patients he has not given in and secured peace by indulging the perverse cravings, but still fights them as vigorously as in the beginning.

\section{HALSTED}

History: He was a clumsy, strong-bodied boy of twenty-one. His parents and four brothers were living. He was the youngest of the family and had been much petted. The father was psychopathic and there had been much family discord. He complained that his wife cared more for her sons than for him, and when he got excited was severe with the boys. While they lived in the country he used to wake as early as 3 or 4 A.M., get up, and wander for hours through the fields and woods. At present he got angry whenever the mother, a timid weak little woman, saw another man, and the situation was getting so intolerable for her that the sons were contemplating taking her with them and abandoning him. None of the sons would remain at home. The second son had spasms until he was five. The mother described the third as nervous and impatient and intolerant of noises, and the fourth as over-active. With the exception of the patient the sons were able to make their way in the world. 
He attended school from five to eighteen, graduating from the eighth grade after repeating it. School was too hard for him he said, and he used to play truant a good deal, going off in the woods with his dog, gun and fishpole. He was always reticent and a great home boy, and didn't play with other boys much when his brothers were away.

Until his next older brother and he were ten and eight respectively their mother slept between them in the same bed, and she remembered that they used to be jealous and each one wanted her to face him and turn her back on the other. The brother then slept apart, but the patient slept with her until well after puberty. It was noticed that he became more bashful and shy after puberty. He sucked his fingers till he was twelve.

The excitable father scolded the mother a good deal and this upset the boy who made faces at the father behind his back. The father said his other sons used to oppose his will at times, but that the patient rarely stood up for himself. Once, however, he refused to hitch up a team when ordered to, and the father chased him off the place with a revolver. He was slow and awkward, and the brothers nicknamed him "clum," short for clumsy. They had been forced to go to work about the age of fifteen and felt bitter over their limited education. They insisted that the patient be given a better chance and advised him not to go to work till he was twenty-one.

The brothers were very affectionate among themselves. One of the older ones took the patient as his buddy, gave him candy and other presents, and looked after him in general. He used to caress this brother's heaf and hair. All of them kissed each other even yet. When one of them visited him in this hospital he called him Honey and kissed him. The father said the boys were fond of wrestling with each other on a bed and the victor kissed the vanquished one repeatedly.

After quitting school at eighteen he went to the city and lived with one of his brothers, and got a job in a parcel check room, studying stenography at night school. He lost that job soon, and then got one as telegraph messenger boy but gave that up because it was too hard. One night he implored his brother to protect 
him, saying people wanted to shoot and kill him. He was sent home, and arrived there in great terror. They soon took him to a state hospital, where he remained for a couple of years during which he made long visits home but could not adequately adjust.

$\mathrm{He}$ had some delusions about his eyes, and hung up a picture of a skull on the wall with eyes punched out and strings running from the holes to all parts of the room. A photograph of his father he called the devil, one of his mother was God, and one of himself was Christ. He said he could turn anything into stone. He got careless of his personal appearance, slept on the floor, and ate with his fingers. The family noticed that he didn't like to be kissed by his mother, aunt, and brothers, and his attitude toward his mother alternated between strong affection and angry aversion. He would spend two hours in the tub and lay with his head also under water. Several times he ran away from home and came back a day or two later disheveled and famished. He never would give any adequate explanation of his behavior. They tried him on farm work as a last resort, but he could not keep his mind on his work. He would stop and laugh to himself. When asked what he was laughing at, he would say at the dog or give some other transparent excuse. $\mathrm{He}$ was finally brought to St. Elizabeths.

Sex life: He had no intention of giving out any information he could possibly hide, and probably feared that he might divulge something that would prove he was sick. He insisted he was all right and ought to be let out. I managed to draw out that he had masturbated about once a month (he told a brother he had done it as often as two or three times a day), and that he had tried heterosexual intercourse at twelve. That was the only attempt, he hadn't much desire later and he felt bashful with girls. Perversions he denied.

Fantasies: $\mathrm{He}$ denied all hallucinations and delusions and gave no outward sign of any. I told him the story of Edipus, and at the mention of mother incest dreams he broke into a sudden knowing smile. ("Did you ever have one?") "Not often, not for a long time." When I pushed the question, he denied he had ever had one. 
He denied wet dreams, nightmares, or dreams of coitus, but said he had day-dreamed of sexual intercourse. He said his dreams were of finding money on trees and bushes, and of going fishing. He also used to imagine himself the boy characters in the Horatio Alger books of which he was very fond.

General observations: $\mathrm{He}$ was a clumsy boy, walking in a rolling, loosejointed manner that had grown much worse in the last two years. His one main idea was to get out of the hospital. $\mathrm{He}$ insisted he was all right, there was nothing the matter with him, and if his family cared anything for him, they would come and take him home. It was noticeable that he preferred to see his father rather than his mother in spite of childhood love for her and fear of the father. (Another case, an eighteen-year-old boy, whose mother incest desires broke into full consciousness, used to greet his father cordially and rebuff his mother, even striking her and shouting, "Take this woman away, I've never seen her before.") He begged money and candy from them like a child.

He had never confided in anyone and was unwilling to do so now. At every opportunity he would run away, even when the father was taking him for a walk about the grounds. $\mathrm{He}$ was deceitful and lied up and down, denying the information given me by other members of the family. He feared the doctors were going to hurt him in some way. He disliked being looked at, and during interviews with me picked nervously at his finger nails. He said that when he lost his jobs his brothers scolded him and he was afraid they might put him in prison for it, so he was anxious to get away from them and did not object to going to the first hospital.

Since he would not talk freely I used the association word test in an effort to discover his complexes, but it accomplished very little because he would not give many free associations afterwards. I made three tests, embodying in the second and third tests the words which aroused emotion in the first. By the time we reached the third test he had learned to give stereotyped responses to nearly all the former complex-indicators.

Eye, lips, mouth, tongue, suck, sucker and swallow were associated together and aroused much emotion and resistance. 
They made one suspect fellatio. Woods and bushes were linked and brought back memories of playing hookey and hiding there from his father with another boy with whom he swam in the brook and also masturbated. Dirty, slimy, and dog made him think of dirty dog. Enjoy made him think of having all he wanted of candy, money, and clothes. Dreams: "Come true, we wish they would." Observe: "Observer, one who looks. People looking at you, I don't like to be looked at. (The preoccupation with eye may have some connection with this. He exclaimed once, "When you say eye, I just can't help thinking of lips.") Voices: "I couldn't think of a word for voices so I had to think up some other. Insane people hear voices. No, I don't." Jealous, hate, kill, murder, die were connected. Hate: "Hateful, they won't do nothing for you, they're mean. To hate anybody is to kill them." Die: "Dead, they're gone." Lazy, work, forget, failure, and pity recalled how hard his family had been on him because of his forgetfulness and poor work. Love, kiss, bad, prick, and cock brought evasive responses after delay. Father, mother, and brother also caused delayed responses. Secret caused a blocking of half a minute, and the response was "secretly." But the longest delay, forty-five seconds, followed spit: "Whistle, Papa spits tobacco." He would say nothing more, and it was impossible to tell whether the emotion aroused by spit was connected with the suck-and-swallow complex or his father-hate.

He escaped from the hospital numerous times and went home. The family often allowed him to remain there a while, but he could not accommodate himself to their life and they were forced to bring him back. After each escape he begged his doctor to give him another chance in the open endocrine ward and promised faithfully never to run away again, and then escaped again at the first opportunity.

Occupational therapy: He was shy and lazy and did not do good work. He worked only part time and sat around a great deal in idleness.

Physical examination: Skeleton normal. Skin well nourishef. Good muscular development. Genital hair distribution normal. Small amount of hair around mid-sternal region and 
nipples. Axillary hair very scanty. Genitalia normal. Extremities rather cold. Type of movement slow and deliberate. Heart rate accelerated. Reflexes hyperactive.

\section{Endocrine diagnosis: Submyxedema.}

Glandular therapy: $\mathrm{He}$ was given thyroid. Treatment was much interrupted by his frequent escapes. No change was seen.

Four months later: During the summer he escaped again and was allowed to stay home for a month until he attacked one of his brothers for refusing to give him money. He had also bulldozed his mother when his father was at work. The attendants reported he was masturbating frequently. No one had seen him do this in the endocrine ward. He seemed worse; more self-contained, introverted, and on the defensive.

Mental diagnosis: Schizophrenia with projection. He had had considerable experience with insane hospitals and in his partially recovered condition was smart enough to hide the symptoms he knew doctors were looking for. He claimed he was all right and wanted to go home, so of course he wished to hide any symptom that he had seen was considered bad. Thus, while he resolutely denied hearing voices in the hospital, on one of his escapes he told his cousin he was going to Union Station to find out about the voices. A stereotyped hospital question is, "Do you hear voices?" As far as could be seen he had no delusions or hallucinations except the vague fear that someone might hurt him. He would rather sit or lie down than work. One never saw him smile or give any indication of enjoying his thoughts particularly.

He had much autoeroticism. The staying in the bath showed skin eroticism, and the association test disclosed oral eroticism if not actual fellatio. It will be remembered that he sucked his fingers for many years.

Signs of his struggle against incestuous and homosexual impulses were his resistance to his mother and brothers kissing him and his alternating affection and aversion for his mother. The flights from home were an attempt at emancipation from the family, but he was not strong enough to stand alone and had to return beaten. His childish relation to his mother and his shy- 
ness and fear of girls prevented his outgrowing the bisexual stage. His extreme reserve rejected all outside help and his only hope of cure was to work out the problem by himself unaided. This he did not seem able to do.

\section{IRGOCZ}

History: He was an Austrian Pole twenty-seven years old. There was no mental or nervous disease in his family with the exception of a paternal uncle who drank and later committed suicide. The patient was the first born and was sickly and delicate as a child. At five he had typhus fever. He attended school from seven to ten and liked it but had to go to work on a farm because they were poor. From sixteen to eighteen he was a laborer and then he emigrated to the United States.

He worked in foundries and factories for rather low wages but got on all right except in the last place. It was too hot, and he noticed the other men were jealous of him because of his good work. They tried to make him mad and looked suspiciously at him. He also believed that the food at his boarding house had been poisoned and complained of it to the police. To escape from the unpleasant situation he enlisted in the army at the outbreak of the world war.

Two months later he was removed from a transport ready to sail for Europe, and put in hospital. His comrades had reported him to be making silly grimaces and talking to himself. His version was that everything was all mixed up and the men cursed him. He was transferred at once to St. Elizabeths.

At first he was tidy and fully oriented and coöperated in his examination. He said he could think and remember as well as ever, while in reality his memory for recent events was badly impaired. Voices called him bad names. Later he went into a catatonic stupor and had to be tube-fed for a while. During the following two years he had become disoriented and untidy, and complained that magnetism was being used on him.

Sex life: According to his statements two years ago he had never masturbated or committed perversions. He preferred girls to boys but seldom associated with them. At twenty he had his 
first heterosexual intercourse, and stopped after four or five experiences. He was much afraid of venereal disease.

Fantasies: On his admission he said he dreamed of being home in Poland and of working in the factory. Now he was absolutely inaccessible, spending all his time in his own thoughts. They must have been pleasant for he disliked any interruption and gave no signs of conflict or distress.

General observations: He was absolutely indifferent to the external world. When standing, his arms were thrust down inside his trousers though not touching his genitals, and he walked with eyes downcast or stood staring by a window. In cold weather he huddled over a radiator, hands clasped over the nape of his neck. For hours he crouched in a heap in a corner, eyes shut and fingers stuck into his ears. He seemed to want to turn in on himself physically as well as mentally. But when the pantry door opened at meal time he was usually the first to reach it in spite of his apparent isolation. As he carried his tray to a table his grin of satisfaction was almost animal-like.

When one forced oneself on his attention he sometimes struck out in annoyance, and then mumbled an unintelligible mixture of Polish, German and English punctuated with guffaws of laughter. I once distinguished the German vulgar term for feces and the ever-present son-of-a-bitch preceded by profanity. He repeated this phrase several times with delighted laughter and then pointed to his teeth. He pressed his lips tight together and pouted them forward and back a great deal. A Polish-born nurse spoke to him in his own tongue, but he rebuffed her like the rest.

Occupational therapy: He remained entirely inaccessible.

Physical examination: Medium type of skeleton. Skin pale. Entire chest and abdomen covered with long, thick hair. Genitalia normal. Abdomen protuberant. Heart weak and irregular. Pupils pinpoint. Reflexes sluggish.

Endocrine diagnosis: Submyxedema.

Glandular therapy: Thyroid was given. The stimulation seemed to force him to extrovert in spite of himself. He dropped his hands from his ears from time to time and looked about him in half surprise as if wondering where he was. He paced rest- 
lessly a good deal and didn't stay crouched in corners so much. The extroversion increased and he was soon pushing a floor polisher and was even induced to do a little basket weaving. The attendant reported that in taking a bath he soaped, scrubbed and wiped himself well. On previous occasions he had made a few passes and tried to get out of the tub and dress while still wet.

Four months later: During the summer nurses reported he had seemed brighter and more alert. He would obey orders and even made beds. He no longer closed his eyes and ears, hung his head, or crouched in fixed positions. He became oriented for place and asked why he was there.

I found him still lost in his thoughts though his eyes and ears were open. His lips were pressed tight together and protruded as before. Instead of looking happy or at least contented he now had a slightly troubled expression.

Mental diagnosis: Schizophrenia with projection. In the beginning at least he projected his difficulties, and believed other men persecuted him, and he heard accusing voices. As the, disease progressed he appeared to give in and to indulge in his dirty fancies. He showed a bit of waxy flexibility which is a sign of submission. The lip tic indicated oral eroticism. He tried to avoid all external stimuli by closing his eyes and ears and striking off anyone who touched him.

The thyroid feeding seemed to force him out of his comfortable fantasy life somewhat into the world of reality. The troubled expression may indicate that the increased pressure of reality has stirred up some resistance to his fantasies, and conflict has again ensued.

\section{JACKSON}

History: He was an enormously fat man with a huge paunch and a voracious appetite. His age was forty and the last eight years had been spent in the hospital. He knew very little about his family. His father drank periodically and he himself had drunk too much he said. An uncle had died insane.

The patient was born in Ireland and came to this country when five years old. He attended school irregularly until he was 
fifteen, by which time he had reached the fifth grade. He worked in a printery, a machine shop and a theater, never earning enough money to live the way he wanted. Most of his jobs were as hostler for wealthy families who let him go when they left for their summer vacations. When motor cars began displacing horses he should have learned the automobile business, he said, but something in him didn't want to.

At the outbreak of the Spanish War he enlisted in the army because he wanted to see the world. After three years he was honorably discharged. There followed a series of enlistments in the army and navy with dishonorable discharges and prison sentences for fraudulent enlistment, drunkenness and stealing. $\mathrm{He}$ finally became upset and believed people were reading his mind and hypnotizing him and forcing him to say and do things he didn't intend to. He became terrified because he was sure some people were going to kill him.

In the hospital he refused to work, did not associate with other patients, and was certain he was to be killed. Voices accused him of vile practices, and God gave him instructions about his eating. He became somewhat grandiose and decorated his clothes bizarrely.

Sex life: He preferred to keep off this subject. With blushing and shame he said that he considered masturbation harmful and had never done it much. The record states he had been caught at it. When he was eighteen a married woman, separated from her husband, had picked him up and he had gone with her for two or three years. He disliked even to admit having had heterosexual intercourse. It was not possible to marry on less. than a hundred dollars a month he said, and he had never earned that much. At mention of perversions he was instantly on the defensive, "Better not talk of that."

Fantasies: Voices used to insult him and call him a fellationist, and he would retort. His brain told him that another man, Satan perhaps, was trying to control him. The tempter agreed that you could do anything you pleased if only you confessed it afterward to a priest; that cleared it all up, but he insisted no, it couldn't be as simple and easy as that, for you would get sent to prison for fifteen years just as some men had 
been sent to Portsmouth for committing perversions. His brain was deadening the other man's brain and keeping it down, so he was winning out (an ingenious dramatization of the conflict with perverse impulses, into which the fear of consequences was injected).

"Before I came here, there was a mindreader who used to say what I thought before I could say it myself. That happens often now too. I believe there are people all around here who can do that.

"Voices talk a lot about the Lord. They say the Lord was assassinated before the birth of Christ. Then the Holy Ghost went to Bethlehem and had a child by Mary Magdalen, which was Jesus Christ." This peculiar jumble seemed to be the old Edipus complex in a religious disguise. The father was killed off in favor of the son, and Mary Magdalen symbolized the soiled mother. The composite Holy Ghost and Christ stood for both husband and son.

General observations: When he first entered the ward he did nothing but sit in a chair, frequently wearing his coat over his head. Gradually he began to extrovert, first singing out of a book, then pushing the floor polisher and finally joining in basket weaving. He didn't mix much with the other patients but seemed to feel no antagonism towards them.

He said that after soldiering three years he thought it was the place of the army to look after him and not try to get rid of him for little offenses. He believed he could earn his living outside now if the work wasn't too hard. However, he was satisfied to be kept and cared for. That was all there was in the world for him. Outside he would have to work for his living, and he was as well off in here as a working man outside with pick and shovel. "I think there are lots of people in freedom who if they were put in here like us couldn't get out again."

Occupational therapy: When the instructor first came to our ward, he sat all day with a coat over his head. In three days she had succeeded in getting him to do basket weaving and he worked every day, improving steadily in ability. He made many mistakes at first and was impatient of instruction. He would willingly work all the time if she could furnish him sufficient 
material. His general mental condition seemed to improve also. Physical examination: Heavy type of skeleton with generalized adiposity, which is exaggerated on shoulders and abdomen. Weighs 248. Skin smooth and almost hairless, though there is a slight beard and some scanty hair about the mammary glands which are enlarged, being filled up with adipose tissue. Fingers are short, stubby and without tremors. Breathing is shallow and emphysematous in character. Penis very small, genital hair normal. Heart rapid. Reflexes normal.

Endocrine diagnosis: Submyxedema.

Glandular therapy: He had been steadily improving for a long time before taking desiccated thyroid gland. But with the first large doses he grew more active, talkative, industrious and complaining, and talked about getting out of the hospital in a few months.

Four months later: After occupational therapy had been discontinued in the ward he began working in the pantry and kept it up industriously. Perhaps the opportunity to get extra helpings of food had something to do with his willingness to wash dishes. The attendants said he had no sleepy spells and was fairly energetic. His mental condition showed no particular change.

Mental diagnosis: Schizophrenia with projection. His difficulties tallied with those of the majority, that is, he had little interest in women and he was struggling against homosexual cravings. His description of the wicked brain trying to control him but losing the fight was an admirable one. He really had gotten sufficient control of his unpermissible cravings to make a happy adjustment to institution life.

\section{KIMMEL}

History: He was a deteriorated patient forty-eight years old who had been in the institution nine years. He had a wife and five children. His mother's father had died of senile dementia and her sister was insane. One of his own sisters had suffered from a nervous affection since she was eight years of age. The others were healthy. 
As a child he was considered normal, but at fourteen a horse kicked him in the head, lacerating the scalp. His father believed the patient's attitude toward him changed after this experience (presumably for the worse though the record failed to specify), and ascribed it to the kick. He left school at seventeen having completed one year of high school. He worked at farming and in his father's store and as a laborer. Around the age of twenty he drank considerably. After marriage he stopped drinking but he was irritable and excitable. He was serving a second enlistment in the navy when he got sick. He complained he had been unable to sleep for many nights and had hard headaches. $\mathrm{He}$ was quite weak. Before reaching this hospital he developed hallucinations and delusions of persecution and had a severe epileptiform seizure lasting five minutes.

The hospital record mentioned no more epileptiform seizures. He had had hallucinarions of all senses and delusions of persecution which made him talk in a homicidal manner. Voices insulted him. At times he was so unruly he had to be confined in the worst ward. He complained of pain in the upper left arm and right leg where he said his mother had cut him. No scars were visible. The right side of his face was somewhat paralyzed. He said other patients talked about him and cut his abdomen. That his head felt bound up and he couldn't think well, and electricity was used on him.

Sex life: During the four months he was under special observation no one heard him mention any sexual matter. $\mathrm{He}$ ignored questions on sex subjects. The records gave no information.

Fantasies: The only audible indications of his fantasies were his angry arguments with imaginary people who thought they did better work than he and depreciated his accomplishments.

General observations: He was an ugly-tempered, unkempt man usually quite lost in his own thoughts and oblivious to the environment. Though once or twice I saw him go into laughing fits he generally sat quiet with head hanging or scolding loudly in great anger. This scolding was almost exclusively about what blockheads and poor workers other men were and how well he 
himself did things though always criticized and never appreciated. Once in a while he scolded about his food. These tirades occurred during the night as well as the day, and in them he articulated with difficulty, making extreme grimaces in which he drew his mouth way over to the left.

Occupational therapy: He was very resistive to the instructor's efforts to interest him but finally consented to try basket weaving and managed to complete two pieces. Every morning he had to be taught all over again as if he had never seen a basket before. Some days he angrily refused to work telling the instructor to do it herself. At any time he was liable to stop work and go into one of his tirades.

Physical examination: Slender type of skeleton. Skin presents a few brown pigmentations, particularly over shoulders. Considerable hair over upper chest and about neck. Genital hair and genitalia normal. Face asymmetrical, elongated on right side. He has generalized arteriosclerosis and there is an occasional stereotyped choreiform movement of the left side of the face. Considerable photophobia. Reflexes hyperactive.

Endocrine diagnosis: Submyxedema.

Glandular therapy: The three day test of tolerance for desiccated thyroid gland had a bad effect on him. His pulse became very irregular and rapid and he showed other signs of intolerance. He grew much noisier. Afterwards he became quiet and somnolent again but seemed to have a little more initiative. For instance, he soaped and scrubbed himself in the bath which previously the attendant had been obliged to do. Because of his advanced chronic heart disease no glandular treatment could be given.

Four months later: His condition was unchanged.

Mental diagnosis: Schizophrenia with projection. His continual scoldings disclosed an inferior, inefficient man magnifying his own abilities and accomplishments and decrying other men who imagined themselves superior to him and failed to appreciate his true worth. If he had a sexual conflict too, it was now buried out of the sight of the onlooker, but his history gave hints that the usual erotic difficulties had once been present. 
His change of attitude towards his father at puberty, his failure to adjust to his home relations so that he left wife and children and served two enlistments at sea, and the voices insulting him were quite in line with the other schizophrenic cases. He probably did not develop a psychosis merely because other people didn't like his work.

\section{LEFFERTS}

History: He was a thin, delicate fellow twenty-nine years old. His father was born in Germany and his mother in Ireland. Most of his family had died of pneumonia. His mother remarried after his father's death, and the stepfather abused him when drunk. She died when the boy was sixteen. He went to school until he was fourteen, at which time he was in the fifth grade. He didn't have much ambition in school and sometimes failed to pass. His first job was in a florist's shop, and he changed jobs a good deal until he was twenty-one, when he became a department store delivery boy. After three years he got typhoid fever and lost the position. He also had had pneumonia and pleurisy. For a year and a half he worked in a boiler factory, and then for a half year as a church sexton until he enlisted in the army at the outbreak of the war with Germany.

Of his army service of two years, a year and a half were spent in Panama. He had malaria there, and felt sickly and without ambition. He was brought back to the United States and discharged in April, 19I9. For two months he worked in a shipyard, then one night in June he felt as if in a trance, as if electricity filled his body. He saw strange visions and heard loud noises. His head and stomach swelled up, and something in his left side swelled up and burst like a balloon, it was a ball of heathen idolaters and other wicked people. There was a swelling in his right side too, but it was good and didn't burst, and his mother's voice from it said, "This is my son," and that pleased him. His eyes felt as if changed, big, hard, and with eyelids wide open. Venus, Mercury, and Jupiter were inside him and talked. The first two were female and didn't insult him, but Jupiter, a male, called him a son-of-a-bitch. The first two 
said he was overloaded with responsibility and that if anything happened to him the world would go to destruction. While going through the backyard to the privy he heard two voices disputing. One said, "Grab him," but the other said, "You can't touch him." He often heard these two voices disputing afterwards. For a week he tried to keep on working, though pestered by visions and voices, then had to quit. He reached St. Elizabeths in August.

Sex life: He began masturbating at eight, and at one time did it daily, but realized it was bad for him and gradually stopped it altogether. He believed he sometimes thought of girls while doing it. He was bashful with girls and seldom went with them, preferring the company of boys. He never had a best girl, and was afraid of rivalry with other fellows over a girl. Sexual intercourse was not much of a temptation. $\mathrm{He}$ feared making a girl pregnant for he hadn't enough money to marry. He was very much afraid of venereal disease.

At Panama, when he was twenty-six, he had his only heterosexual experiences, a half dozen in all, but got very little enjoyment or feeling out of them. "Something ran through my mind." He soon tired of it, and the fear of disease was ever present. His night orgasms were infrequent and when there was any dream at all in connection with them it was of normal coitus. He had never committed perversions.

Fantasies: The kernel of his trouble, he declared, was that there was something in him that if taken out might do great damage, and only the devil knew what that something was (perverse impulses?).

He dramatized a struggle between two forces, good and evil like the two disputing voices. He himself was good, backed by visions of saints in white, crosses in the sky, and a full regalia of crowns, balls, candlesticks, and moons such as decorated his home church. A grandiose element entered in also, he was head of the. Catholic, Jewish, and Turkish religions, higher than the pope, in fact he was too good for this earth and was expected to rise to heaven. He had been the sun, Moses, and St. Patrick, and had been crucified several times. When he was killed in ancient times, the world came to an end. 
Opposed to these good Catholic forces were the Masons and other wicked secret orders, backed up by various devils and accompanied by visions of carpenter squares, scimitars and other fraternal symbols. Voices accused him of having founded these orders long ago, and their members came to his bedside at night and tried to get him to join the orders and to indulge in their orgies of fellatio and cunnilingus, but he resolutely refused. Gradually the orders developed into three; the first was of earth and pretty good, the second was of the devil and belonged in hell fire, the third was his own order, not hostile to the Catholics, and belonged in heaven. He had no visions in the day time, but at night he had them frequently. One night when I entered the ward in the dark he saw horns on my head, and when Vincent was having an epileptic fit he saw little devils jump out of his mouth. "The devil shan't get into me," he exclaimed, "I could catch him from some other fellow, but I fight temptation."

He was sure his eyes and testicles were removed during his sleep and others inserted and that the same thing had been done to his father. He had a fantasy that he had been in Germany, and they had tried to operate on him there and take out his testicles to put them in some one else's scrotum, but they all dropt dead and lost their own power instead (struggle of father and son to castrate each other. His father had been born in Germany).

He had many physical delusions; he was drawn along by the head as if by a magnet, he grew small and then stretched out to normal size accordeon-like, he was done up in a ball, and he felt something go down from his head and out near the pubic region, and something else rise to take its place. (During this period he lost his potency and had no erections and had only one night orgasm for six months. Voices told him he would never have children.) Something had been taken out of him, and no one had a right to do it. He had Adam and Eve balls, the right testicle came from Adam, and the left one from Eve. His testicles had sprouted like growing beans.

There was often a buzzing like a dynamo in his ears, and he heard many voices. They called him good and bad names, 
threatened to kill him, said the devil must keep away from him, ordered him to commit fellatio and cunnilingus and submit to fellatio, and compared a mouth to a vulva and wanted mouths and vulvas to kiss one another. They never mentioned pederasty.

He dreamed of his parents as he remembered seeing them at the time of their death, on bed and in casket, and it made him feel badly, for if they had lived he would have had more advantages and not been forced to go to work too young.

General observations: He was a thin nervous fellow, awkward, restless, and emotional, and with protruding eyes. His behavior was unvaryingly good, but he said he often felt very irritable and just like springing at people and walloping them. $\mathrm{He}$ had no insight into his psychosis and insisted that he really did see and hear these things. If other people couldn't, they were the ones that were crazy, not he. $\mathrm{He}$ was very stubborn and obstinate in clinging to his delusions and did not want to listen to any psychological explanations, but interrupted constantly to give the true version, namely his. $\mathrm{He}$ was, nevertheless, always courteous, friendly and humorous.

After working for two months I had made no progress whatever with him. Then he pricked his thumb and got a severe infection of his whole left hand and wrist during which part of the thumb had to be amputated. He was sick for a month and meanwhile his psychosis evaporated. "The voices and all are dying away, and I see no more visions. The voices told me those strange things. Perhaps they were fakers and didn't tell the truth. I don't believe them now. Once in a great while I hear a voice but I pay no attention to it. I had a mental disease, I guess. After they put me under ether to cut off my thumb the visions began leaving. There was something inside me, talking to me and trying to control me. It sets your brain on fire. You don't know what you are doing. You might go out of your head completely. I wouldn't give in, I fought it. The voices asked if I did fellatio and cunnilingus as if they wanted me to start doing them."

During the month following this explanation he gained physically and in emotional control, and then gave this version, "There was a struggle on all the time, some force trying to get control 
of me. I fought it all the time and finally won out, and now it's gone. ("What would have happened if you had given in?") Why, something awful. I probably would have gone and done those bad things they wanted to make me do." He believed he had cured himself unaided by anything or anybody and resisted my explanation of the phenomena just as obstinately as during the psychosis. He much preferred to regard it as supernatural. When I called his attention to Garland reacting angrily to his hallucinations, he replied, "He has the power to see things that you and I can't."

I tried very hard to give him some insight into the delusions he had suffered, but in vain. His superstitions were sufficient to explain everything satisfactorily, and it was undoubtedly much pleasanter to believe he had triumphed over a vile external foe than to recognize that the tempters were his own repressed desires. He hung on grimly to the belief that these hellish and heavenly visitors had been real and he just knew that such things could happen.

After six weeks I was startled to discover that the delusions had returned. There was a woman inside him, and "they" were accusing him of being a Protestant. Devils sported around, and something inside him was trying to drive him wild. The nights were full of demons, bats, angels and all. The delusions were not systematized again however, and no Masons tempted him to commit perversions.

It was useless to argue with him or to recall the interlude of the infection. These spirits had departed at that time and now they had returned, that was all. His conduct remained good and he still used his parole of the grounds. He didn't do much but sit around indifferently.

Occupational therapy: He was interested from the beginning and very anxious to work, but was nervous, obstinate and wilful, refusing instruction, saying he knew how and then blundering ahead with many mistakes. Once when he got all tangled up in mistakes he burst into tears. Gradually he became less nervous and more careful. His infected hand put an early stop to his work. 
Physical examination: Skeleton slender. Dome-shaped palate. Perspires easily. Radial arteriosclerotic pulse under tension and rapid. Hair, normal male distribution. Genitalia normal. Thyroid gland, both lobes enlarged about one third and isthmus is hypertrophied. A noticeable exophthalmos with eye globes under tension. Fine toxic tremor of fingers. All reflexes extremely exaggerated.

Endocrine diagnosis: Hyperthyroidism.

Glandular therapy: None. Even the thyroid tolerance test had to be stopped on the second day because of his excessive reaction to it.

Four months later: He still had parole and his behavior was exemplary. The hallucinations and delusions persisted, but were not yet well systematized again. He said there were men and women inside him, and they put things in and took things out of his body, particularly his eyeballs. The symbolism was as rich as ever with Scottish rites, Satan and the rest.

Mental diagnosis: Schizophrenia with projection. His own explanation of his psychosis at the time of the infection was very accurate except he would not admit that the "force" came from within rather than from without himself. The coincidence of the disappearance of the perverse cravings with the height of the infection makes one presume a connection between the two phenomena, particularly since there are records of many similar cases in which severe infections apparently cured psychoses.

During the dominance of the perverse tendencies his sexual power was lost, probably a suppressive act of self-defense. I have found this phenomenon in many similar cases. When the improper impulses are again well repressed, potency returns as it did with this patient. It will be recalled that he stated something had been taken away from him, that his testes and eyes had been removed (since some eyes and testes were there, he had to invent the theory of substitution), and that voices told him he would never have children. His delayed sexual development was shown by his timidity with girls, his fear of fighting another male for the girl he might want, and his lack of satisfaction in coitus. 
His gradual alteration of the, at first, totally bad fraternal orders was interesting. They became three in number: one, 2 male symbol, was "pretty good;" two, symbol of the female genitalia, was bad and belonged in hell fire; while three, symbol of the male genitalia, and normal coitus, was his own and belonged in heaven, that is, his male cravings were triumphing over his female cravings and repressing them.

\section{Mathews}

History: He was a jack of all trades who had been in the hospital twelve years. His age was thirty-four. The family history was negative. The father had been a peddling butcher in a country town. He drank heavily and one cold night fell out of his cart and died from exposure. The patient was then seven years old. The mother was nervous and excitable. She had twelve chidren; six by her first husband ; five by her second husband, the patient's father; and one by her third husband, whom she later divorced.

After his father's death the patient quit attending school regularly and went to live on a relative's farm where he was allowed to attend school winters until he was twelve, at which time he had reached the fourth grade. During the rest of the year he did farm work. His stepfather didn't care for him, and the boy didn't want to stay home. After his mother's divorce he returned to her and helped her keep a country store winters, and worked on farms summers until he was fifteen, when he went to the city. When he was seventeen she died of hernia.

From fifteen to twenty years of age he had a long series of changing jobs, lasting from one day to a year and a half (on a farm), and including such varied occupations as riveter in bridge works, store clerk, miller, teamster, shoveler, carpenter, and physician's man of all work. Sometimes the work was too hard. other times the pay was not big enough. If he got tired he'd move on, and he wouldn't wait to be fired when people didn't like him, he'd get out. Finally, out of work and tired, he enlisted in the Marines for a secure and steady life and within two weeks was in this hospital, diagnosed dementia precox. 
At first he was restless, incoherent, irrelevant, sometimes abusive and threatening, and always complaining. He didn't want to stay and demanded his release, but never seemed put out when his many requests were refused. He also had quiet, stupid periods which lasted for months. His own present version of his psychosis was that he had been very nervous and restless, and his mind wandered. A thousand different things would come into it during a day, including bad thoughts that weren't really so. He feared the attendants wanted to kill him, and believed other people called him vulgar names, and his conscience bothered him. He would try to choke himself with a towel, and beat his head and elbows against the wall. His clothes burned his skin, so he took them off, tore them up and threw them out the window. In the fourth year he asked to have his throat operated on (it was thought because of tonsilitis). In the eighth year he was reported to be more interested and extruverted. He was neater, tidier, began to work, and gave no trouble. In the ninth year it was noticed that his thyroid was enlarged. This was followed by protruding eyeballs, tonsilitis, and acute articular rheumatism, and he complained of perfectly sound teeth. His mental condition cleared simultaneously, and remained clear. The exophthalmic goiter remained, the other maladies disappearing.

He said when a boy his neck bothered and hurt him, especially the "left muscle," and he noticed it most when running. $\mathrm{He}$ also remembered stories of sheep and heifers escaping from his father's knife and running wildly with bleeding throats.

Sex life: At eight he committed mutual fellatio with a gypsy boy. Soon afterwards he began masturbation. Then he attempted coitus with his sister, who was one year older. He used a heifer at ten. He got his first orgasm at eleven or twelve, and was wearing long pants at the time (date probably not accurate; he said his memory had never been good). He used to have masturbation races with a negro boy. After puberty he had several coiti interrupti with his sister. Wet dreams frightened him. He believed it was injurious to let semen remain in the body, for it might corrupt the body. The semen ought to be got rid of. $\mathrm{He}$ 
masturbated excessively. At sixteen piles became more or less chronic. At seventeen, when he moved to the city, he had coitus with a prostitute. He had had five or six in all, and once was impotent, but on returning home he masturbated and obtained an orgasm. Coitus was unnecessary he explained, because he could masturbate at home, which he did nearly every night. $\mathrm{He}$ had felt "good, hearty, healthy and enjoyed life." At that time he used cows and mares.

In the hospital he continued the masturbation and committed fellatio with other patients a few times. He consented once to allow pederasty, but it hurt so much that he made the other man stop. He also masturbated on the bodies of other patients. $\mathrm{He}$ remarked with wonder on the hardness of other patients' penises and said his own was half flabby. These incidents he related with some shame, but said he had repented and felt forgiven. $\mathrm{He}$ had rationalized masturbation as being necessary (" a man must do enough to live"), and there was no mental conflict in connection with it. Day masturbation he had given up, but if he couldn't go to sleep at night he masturbated and then slept well. This occurred on the average of every other night. He had had only two night orgasms in his life, one without a dream; in the other he dreamed of heterosexual intercourse and awoke to find himself in the sexual position on the farmhand he was sleeping with.

Fantasies: The only waking fantasies he had were of heterosexual intercourse while masturbating. As a boy he dreamt of being chased and caught by the police, and waked up out of breath; of building a fire; and of seeing his father butcher a cow upstairs and hang up the quarters. The quarters frightened him very much. He had always been timid at night.

More recent dreams were of being home again; of seeing the face of a handsome negro girl who worked in the hospital kitchen; of a nurse who sat down on his bed and, when he put his arms around her, fainted; and of his half-brother hacking at his goiter with a knife. This last was "terrible."

General observations: Physically he was a thin, nervous, quick-moving man with large goiter and protruding eyes. Ex- 
ercise tired him very much and he seldom went on walks, preferring to remain in the ward and work on raffia baskets. The ward attendant made an assistant of him; he helped serve meals and look after and govern the retarded and deteriorated patients.

$\mathrm{He}$ dated his mental recovery from the onset of the goiter and said he didn't tire as easily and felt in better health than before the goiter appeared. His memory for events during the psychosis was not as good as for events of his life previous to it. He took an intelligent interest in everything and was of assistance to me in reporting the behavior of other patients.

Occupational therapy: No urging was necessary to get him to begin work; he was only too glad to find something to do and kept at it incessantly. After learning how to weave a raffia basket he was satisfied to make one after another in the same pattern, and his weaving was always slack and loose. He hated to try a new pattern and did so only under compulsion. The same old way was easiest, and he had no desire to change it. His baskets sold readily and brought him in quite a little pocket money.

Physical examination: Medium type of skeleton. Skin normal in color. Pubic hair normal, but hair absent from rest of body with exception of slight beard. Genitalia well developed. Perspires easily and profusely with skin always damp and clammy. Superficial reflexes hyperactive. Deep reflexes normal. Pulse 96 , full and bounding. Thyroid region is bilaterally greatly enlarged with prominent superficial veins and bruits which may be heard by stethoscope on both sides from the bases of the ears to the clavicles. There is a striking exophthalmos with several of the eye signs of exophthalmic goiter in evidence.

Endocrine diagnosis: Compensatory hyperthyroidism.

Glandular therapy: A successful thyroidectomy was performed, about half of the goiter being removed.

Four months later: $\mathrm{He}$ had entirely recovered from the operation and felt stronger and better. The annoying pulsation in his neck was gone, and he no longer woke up at night out of breath. His mind was as clear as before the operation.

Mental diagnosis: Schizophrenia with projection. The incest, bestiality and homosexuality in this case were out in the open. 
The usual resultant impotence was present also. During his psychosis he projected his improper desires into voices, felt sinful, and punished himself physically. At times he gave in to his perverse cravings. Coincident with the development of his goiter these mental symptoms disappeared. He spoke of his past transgressions with embarrassment but felt that they were forgiven. He had adjusted himself well to hospital conditions, having reduced his sexual activities to masturbation and rationalized that as necessary and so permissible, and was contented.

His mind seemed perfectly clear and his judgment fair. $\mathrm{He}$ lacked self-confidence and initiative but that can hardly cause surprise in a man who had spent thirteen years in an institution. If he could be cured of his hyperthyroidism, he thought he might adjust to life outside and earn his own living as a farm laborer.

Since the advent of the goiter was coincident with the fading of the psychosis, it could be regarded as a compensation for the latter. In that case a removal of the goiter might be followed by renewed psychotic symptoms. Perhaps not enough was removed to have any such effect, but certainly the patient's mental condition became no worse.

\section{NoLAN}

History: He was a fat, childish-looking moron of twenty years. His mother was very nervous and had spells during which she "sat down and took things easy." One sister had hysterical spells after which she was confined to bed for a week or so. He was the youngest of the family and his mother's pet. He attended school until fourteen and reached the fifth grade. Then he worked as grocery boy, teamster, and expressman for various employers, staying from two to six months in a place and leaving for higher pay. He claimed he never was fired.

$\mathrm{He}$ enlisted in the navy in June and went to sea on a battleship in August. The other sailors teased him, probably on account of his boob looks and slow mind. They hid his hammock and blankets (he could not tell of this without weeping), and said he ought to make a lot of money with his fat rear, but he "sassed them back." 
After two months at sea he became nervous and unable to concentrate, disobeyed orders, and got into trouble with the officers. He was put in the brig, which broke him up completely, and was transferred to a hospital when the ship reached port. He had an obsession that he had been forced to commit some act that was wrong, and he heard voices saying that on account of what he had done he would be buried in a Protestant burying ground instead of in a Catholic cemetery. The voices were sometimes pleasant and sometimes accusatory. He was emotionally unstable, varying from cheerful talkative periods to fits of weeping.

Sex life: He had masturbated two or three times a week. His first heterosexual experience was at seventeen, and he had had many since. He had never committed perversions, but had felt tempted to allow pederasty on the battleship, and had about decided to submit if solicited any more.

Fantasies: By the time I saw him he had recovered from all but sexual hallucinations and delusions. When first taken sick he thought he had syphilis because he saw a man write four X's on a bottle. He saw various visions: his mother's smiling face in the clouds surrounded by red, white and blue, a little garden of angels, and a red devil on a blue ball between two lights. He had been very homesick and used to hear "spoken letters," that is, the voices of his family and friends saying to him just the things they would write in a letter. He thought some one had doped him in the nose. Around Christmas time he said to himself that he "must stop this stuff, this talking and thinking, that that was being sick," and from then on he had no more visions and heard no more voices.

One night in January the night nurse saw him get out of bed and with a shoe start beating little O'Neil who was sound asleep in the next bed. My inquiries as to the reason for this attack brought to light some sexual delusions. While in bed just after his being sent to hospital he complained of a pain in his abdomen. A sissified male attendant felt of it, and then remarked to some others that "it was tight." He took the remark to mean that the attendant had committed pederasty on him during his sleep 
and found his anus tight. He heard the doctors tell his mother he was in no condition to go home, and he interpreted that as meaning he had been raped in pederasty. He began to fear he might become pregnant and have a baby in his rectum. His relief was great when I assured that it was impossible for a male to become pregnant and that no one could assault him without waking him up.

The reason he attacked O'Neil was because in his sleep it had felt as if his thighs and abdomen were being licked and then his penis sucked. When he woke he suspected O'Neil had been doing it, but had already discovered the latter was fast asleep before the nurse interfered. He was not convinced by my explanation that it was only a dream. It seemed too real for that. A fellow sailor had told him about this fancy method of fellatio and he had thought it must be very pleasant, but he roused himself from sleep because he didn't want an orgasm, for that would sap his strength.

Now he had delusions of reference. If other patients moved their lips and tongues, his penis felt as if it were being sucked. He complained that they looked at him and made him uncomfortable, that they ought not to grin at him, and that they seemed to be making signals to him. Finally he struck Dixon in the head, and only the timely arrival of the attendant prevented a fight. My attempts to explain projection to him made no impression and I had to merely order him to pay no attention to the others and, when they annoyed him, to go some other place. He was very indignant and looked like a thundercloud for a week, then became very happy. ("You were cross a few days ago.") "You can't be happy all the time. I had a little headache and didn't feel very good. I don't know why I thought other fellows were making signals to me, and thinking dirty thoughts. Now I don't feel that way at all." He told me also that his ears used to itch and then he thought spirits or something were reading his mind.

In March after hearing Carhart's diatribes about being locked up he "almost heard" voices say he would never get out of here, and he anxiously asked me the truth about it. This was the dying 
gasp of the psychosis. He came to look on it all as imagination.

General observations: $\mathrm{He}$ was a big, fat boy with a boob face, and his behavior was what might be expected in a child of his mental age, nine years. At first he was much worried over his body and always had a new pain or ache or funny feeling. He examined his phlegm and feces to see if any nerves had come out in them, and took great satisfaction in an enema. He was emotional and wept on any provocation, particularly at mention of home and mother. He said she loved him most of any of her children, and he felt he ought to behave well to please her, and explained what a good boy he had been at home, coming in after a ten-hour work day and chopping wood for an hour so his father wouldn't have to.

He was exceedingly lazy, sitting or lying down most of the day, and refusing to aid in the ward work. When reproved by a Red Cross girl and told she would give him no more gum and candy if he didn't work, he got very busy until she was out of sight. The nurses tried in vain to get him to help in the pantry until they offered him extra food. After that he was most faithful. When forced to go without breakfast on the day of his sugar tolerance test, he was deeply grieved and turned his face to the wall because he could not bear to see the other men eat. His appetite was enormous.

It was evident he had been teased and ostracized on account of his childish appearance and dull wits, and he had kept to himself largely through fear of rebuff and ridicule if he made friendly advances. The vocabularly test in the Stanford Revision intelligence test proved to be a good complex-indicator for he invented meanings for every word he didn't know, and many of these definitions showed a desire for friends and the feeling that other people didn't want him around and took advantage of him. Examples: mosaic, to mose around with someone who doesn't want you; tolerate, to tantalize one who is under you and can't protect himself; brunette, to be brewed with someone, to be needy, to nag someone; ochre, to be an ochre with someone, to have friends, be chums; achromatic, to be very achromatic with someone, to be friends and chum with; outward, to be 
outward with someone, to be awkward; civil, to be civilization with everyone, correspond with them, enjoy their company, be kiddish; piscatorial, pispatorial, have a steady leak out of a vein or something; sudorific, to be satisfied, don't let them leave the store till they are well satisfied; lotus, you have a low test in examination in school.

Occupational therapy: For the first two days he was induced to cut a few basket spokes, but after that he quit absolutely and just sat and lay around.

Physical examination: Weighs 173 . Tall, undeveloped type of skeleton. Protuberant abdomen and general obesity of whole body. Skin smooth, pink, and hairless except in genital region, in which hair is scanty and of feminine type. Genitalia normal. General behavior sluggish. Facial expression that of a young child with small, fat rounded cheeks and pale blue eyes. Heart normal. Reflexes normal.

Endocrine diagnosis: Hypothyroidism and infantilism.

Glandular therapy: Desiccated thyroid gland worked a veritable transformation on this boy in the three-day test. From a lazy listless lump he suddenly became active, industrious, worked all day long on basket weaving and planned the next day's work ahead. Like a different fellow, wonderful change, shows so much constructive intelligence, were the comments made by attendants and occupational therapist. The improvement continued after the conclusion of the thyroid test. The first Stanford Revision test, in January during his listless period, gave a mental age of eight years and seven months and an intelligence quotient of 54 per cent. The test just after the thyroid feeding, in March, gave a mental age of eight years and nine months and an intelligence quotient of 55 per cent. Later on, a moderate dose of thyroid was given him daily, and he improved steadily. In May, his mental age had risen to nine years and eleven months and his intelligence quotient to 62 per cent. Soon afterwards he was discharged as recovered.

Mental diagnosis: Schizophrenia with projection, in a moron. His homosexual cravings were evident, sometimes becoming a conscious temptation, but usually being projected. His moral 
self had a feeling of sin and resisted the cravings, which were repressed without insight before glandular therapy was begun. The latter treatment made him more alert and energetic, and speeded his recovery.

\section{O’NEIL}

History: He was a sturdy little fellow twenty-one years old, and had always lived on his father's farm until he was drafted into the army. He got on all right on the farm but was never bright at school. He claimed he reached the eighth grade when he was eighteen. The Terman intelligence test proved him to be a moron.

He found it difficult to adjust to the new conditions in the army, and it was very hard to have to leave home and mother. $\mathrm{He}$ had no complaints to make. He denied with some heat a question whether the other boys ever made fun of him. "What right had they to?"

He had always drunk in moderation. In France he was sent to a hospital because he was resistive, depressed, and worried over the "recent death of his mother from pellagra," and feared he was going to get it and die too. He became more depressed and emotional, and declared the Germans had won the war because he hadn't taken baths regularly. In tears he begged not to be put into a machine and ground to pieces. He refused food and said he was going to die.

On admission to this hospital he was disoriented, preoccupied, resistive, could not remember well, and denied hallucinations though he appeared to be hearing voices. He stood at a window for hours.

Sex life: He admitted having masturbated two or three times a week at one time, but he did it no longer. His first heterosexual experience was at eighteen. He had had several, always with prostitutes. He denied any knowledge of perversions with every sign of sincerity.

Fantasies: He had a great habit of snickering and laughing to himself, which at first I suspected might be due to fantasy but after further study of him decided was in response to external stimulus. He watched everything and everybody and broke into 
frequent gleeful chuckling whether their actions seemed amusing or not. He never would tell what he found so funny in all about him. "It's better to laugh than to cry. It doesn't do to tell everything you know, does it?"

Of the fantasies reported in his record he denied any recollection whatever. "I never told them nothing of that. I never thought it." He said his mother had had pellagra before he entered the army but recovered and was now living. He had never believed she was dead. He denied hallucinations and delusions, but said he had been nervous in France and had shaking spells that lasted for an hour during which he felt cold. He denied he was afraid of anything. Now his nervousness had disappeared and he felt as well as he ever did. His amnesia for the psychosis seemed sincere. His memory for recent events was excellent. If I chanced to ask him a question I had asked even three months before, he would retort, "I told you that once." ("Do you remember everything you tell me?") "Certainly."

General observations: At first he stood all day by a window reading. Any book would do. I couldn't ascertain whether he comprehended what he read or not, for in answer to any questions he would push the book towards me, saying, "There it is, can't you read?" This resistive attitude he displayed towards everybody, and seemed perfectly satisfied if left alone. He never gave any trouble.

I tried the Stanford Revision intelligence test on him in January and found his mental age to be just eight years, intelligence quotient 50 per cent., the borderline between a moron and an imbecile. His negativism I considered to be partly a defense reaction against revealing his low intelligence, for he seemed to have no unfriendly feelings towards other people. For a month he would do nothing but read, but on offering extra food the nurses got him to help in the pantry and he continued to do steady, efficient work there. About two weeks after beginning dishwashing the occupational therapist induced him to try wood carving, and he soon did very well. During a physical examination he was very nervous, giggling hysterically, and responding exaggeratedly in all reflexes, but insisted he was not afraid. 
He improved slowly and steadily, and was granted parole of the grounds in April. It was not possible to ascribe his improvement to any particular factor. He saw he was in friendly hands and so began to lose his apprehension, he liked the wood carving, and he seemed pleased to be given glandular therapy. That was medicine, the kind of treatment he was familiar with for sick people. None of these factors seemed to alter the steady course of his recovery.

In May his behavior had become fairly normal, and the silly giggling had almost ceased. The intelligence test now showed a mental age of nine years and three months and an intelligence quotient of 58 per cent., a gain of fifteen months and eight points in five months' time. His father came to town to attend a convention and made him a visit. After he left, the boy came to my office of his own accord, the first time he had sought anyone's company since he entered the hospital. He had received a great shock and wanted sympathy. His eyes were wet with tears, and he showed the emotion natural under the circumstances with none of the old aloofness. He had asked after his mother and was told that she was dead. She had died while he was in France in the army, and his father said they had written him the news at the time. The discovery was a severe blow, for he had felt sure she was alive and that the records were wrong in stating she was dead.

"I was a great mother boy, and home won't be the same now without her. It was hard to leave her and home, and go to war. I unloaded cars in France and sometimes had to work till late at night. I got very tired. The first I noticed of the sickness was that my hands and face got numb like going to sleep, and my feet got cold. These spells lasted from an hour and a half to two hours, and my mind was clear during them. I felt smothered, I couldn't get my breath, I felt as if I would die. I couldn't lie down, I must have air. Every bone in my body ached. Between spells I felt all right. These spells lasted nearly up to the time I reached this hospital. Now I understand about the letter telling of my mother's death. It must have come after I got sick, and the doctors were afraid to give it to me, so they just put it in the records. 
"I felt strange here. Nobody was introduced to me. I didn't know the names of the nurses and attendants. I felt lazy and wanted to be left alone. It's hard to talk to strangers. I don't know what to say. You weren't friendly enough at first, you didn't smile at me. Now I feel better and I want to get to work. I feel better than I did at home before I was drafted, and I weigh twenty pounds more."

About sex matters he said he had heard of bestiality at home, but he had never seen it done nor done it himself. He had always tried to keep nice and clean. In camp in France he had heard of pederasty but had never been solicited; he would have told them where to get off. It was dirty and probably painful. $\mathrm{He}$ had never had any ideas or fears about such things when he was sick, though he realized that other fellows did (this knowledge and the phrase "nice and clean" may have been acquired in the endocrine ward).

His father took him home.

Occupational therapy: For a long time he refused to try any handicraft, but two weeks after he began dishwashing in the pantry he reluctantly consented to mark holes on a tray bottom. In spite of his "I can't do it" the instructor led him into wood carving which he soon did very well. She thought his resistance was due solely to fear of failure. As soon as he saw he could carve well, he stopped his reading completely and carved steadily until he got parole of the grounds.

Physical examination: Short, heavy-set, pink-skinned. Plethoric-appearing face. Hairless over abdomen and chest, but with male type of genital hair distribution, though somewhat limited. Genitalia somewhat flabby. Body in general excellently nourished. Heart beats regular but very fast. Shows very rapid carbohydrate metabolism. All deep reflexes extremely hyperactive.

Endocrine diagnosis: Submyxedema with hypoadrenia.

Glandular therapy: Desiccated suprarenal gland was given for three or four weeks. No sudden change in behavior was noted. His steady improvement continued with no apparent acceleration. 
Mental diagnosis: Schizophrenia with projection, in a moron. He seemed perfectly sincere in his amnesia for all the mental manifestations of his psychosis. All he remembered was that he had felt cold, nervous, and breathless, and trembled a lot. Finding it very difficult to adjust to the strange new conditions, the news of his mother's death was too much to bear, and he sought refuge in a psychosis. His apparently ridiculous statement that the Germans had won the war because he hadn't bathed regularly becomes intelligible if interpreted as a symbolic way of saying that he was dirty (mentally) and the enemy (improper impulses) was therefore getting control of him. The usual depression and sense of unworthiness with fear of punishment and death followed. His catatonia was a form of self-protection against assault.

As he recovered he developed complete amnesia for the mental content of the psychosis including his mother's death. Along with the repressed perverse cravings went the memory of any previous knowledge of such matters, and he was quite honest in declaring he had never heard of them. After his recovery he regained the memory of sexual ideas that he had held previous to the psychosis, but he still had amnesia for his mother's death and had to suffer the agony of her loss a second time. But the war was over now and home was in sight, and he could endure the shock.

\section{PURDY}

History: He was a slender, serious-looking man with iron gray hair. His age was forty-two, and he had been in this hospital once before. He denied that there was any mental disease in the family but his parents had both drunk. He was the oldest of six sons. He reached only the third grade in school. When six years old he was struck by a train he said, and remained unconscious for three days.

$\mathrm{He}$ had been a wild boy and liked to be a leader in mischief and daredeviltry. He stole papers from news stands and coal from railroad cars, jumped trains and threw bricks at trainmen from bridges, and tried to excel in stone throwing and high diving. Sometimes he'd stay away from home for a night or two. 
These escapades infuriated his father who punished him brutally. He was tied up by the thumbs naked and beaten with straps, and chained in the attic and fed only bread and water. The boy would loose himself and escape by climbing down the water spouts. When his father was drunk he was knocked and kicked about. The mother tried to protect him and even stepped between them, receiving the blows herself. The next brother two years younger, was a pet and didn't get such abuse, so the patient felt jealous and used to beat him up himself, though he would not allow the other boys to do it.

When he was seventeen he was framed up on a charge of stealing coal from cars, while all he had really done, he claimed, was to pick it from the tracks. He was sentenced to reform school for a year, and this injustice started his tendency to be suspicious. He was unruly in the school and was frequently punished. This lengthened his term from one year to three. From his associates he received a thorough schooling in crime which he never put into practice however.

Before his term was up, his father was accidentally electrocuted, and he was pardoned. He realized now that he ought to take his father's place in the family, but he lacked self-confidence and felt unworthy and unequal to the task. He noticed that his affection for his mother seemed to change over to the memory of his father. He wanted him back and cooled down towards her.

The Spanish War broke out a few months later and he enlisted gladly as a means of escape. On his return from Porto Rico he had fever and was depressed. He felt that humanity was cruel and that life was a fight. $\mathrm{He}$ was not skilled in any trade and had trouble in getting work. The next youngest brother was away at work and the other boys were in charity institutions, so he and his mother lived alone. When she got drunk she had spells of raving during which he held her on the floor. This made him feel very badly. He had contracted gonorrhea in the army and began to worry over whether he might infect her with it. When I asked him just how he feared he might infect her, he said through using the same towels. Finally he abandoned her in 
poverty. She died soon afterward, and his treatment of her caused him much remorse.

At twenty-five he married and had two children. One died in infancy but the other, a boy, was still living. He was not successful as a worker and did not provide well for his family. In hard times his wife took the boy and went to live with her mother, and then she got the habit and left him when he didn't consider it necessary. Finally she left him altogether and demanded alimony. He became worried and was committed to this hospital.

His disease was diagnosed hebephrenic dementia precox. The records state that he had felt badly for three years and had had delusions that his employers persecuted him. He greatly feared impotence and believed he had syphilis. He had strayed away from his church and joined a fraternity which now prevented his becoming a Knight of Columbus, and all these things had worried him. His wife said that their married life was very unhappy. He gambled and drank to excess, though seldom getting drunk, and refused to support her. He accused her of infidelity, called her a prostitute and swore the boy wasn't his. He accused her also of all sorts of immoral practices. One night he had stolen into her room and tried to strangle her, but the child's screams frightened him away.

In the hospital he was depressed and sure he was doomed to die. He nearly succeeded in committing suicide by hanging. $\mathrm{He}$ dreamed he was to be the mother of fifteen little devils, and he felt that a good and bad spirit had possession of him at different times. The delusions were fairly fixed in character but his belief in their reality was inconstant. Following an operation for varicocele, which he held largely responsible for his impotence, he improved rapidly and was discharged as a social recovery thirteen months after he entered the hospital.

For the next three years he led an easy life as electrician in a soldiers' home. When the United States entered the Great War, he became restless, feeling he should do his bit, and left the home to work in camp construction. He tried to get in touch with his wife and child, but the grandmother would not let him see the 
boy and said his wife was dead. After the armistice he went back to work for the same contractors whom he had suspected of persecuting him before by giving him all the hardest jobs. Soon the other men began to kid him and say, "Own up, Purdy, that you're a fellationist," and that "broke him all up." He became much upset, and was brought here a second time.

Sex life: When about ten years old he was sleeping with his mother's sister and rolled against her in bed. He had an erection and was making copulative movements in his sleep when she waked him by pushing him away. $\mathrm{He}$ masturbated once or twice a week throughout adolescence and then slowed down, but revived it again in the army. In the reform school he committed pederasty once and allowed fellatio. An older fellow offered him some much coveted tobacco if he would allow pederasty. He refused but consented to allow coitus inter femora from behind. They were caught and accused of pederasty, and this lengthened his term.

A few weeks after he was pardoned at the time of his father's death his mother sent him to have an interview with her confessor, a man she respected greatly, in hope that the priest would exert a good influence on her wayward boy. But the priest after praying with him took him to a bedroom and began to play with him sexually. He was unable to accomplish pederasty but did coitus inter femora. The shock to the boy was extreme. He knew such things occurred in penal institutions, but to find that a priest of the church did them was a blow. He reasoned that if this respected man did them, so must the rest of the clergy. All priests and preachers were hypocrites, and the church which to him had been the holiest thing in life now became despicable. He pictured the poor " with their noses to the grindstone to earn money to support the gold cross whose priests were rotten. And if the priest would seduce me under the cloak of religion, wouldn't he try to seduce my mother also?" (He showed great emotion in recalling these memories.) After this experience he never felt the same again either towards the priest or his mother. $\mathrm{He}$ was disgusted with him and her and himself, with his brothers, with everything and everybody. It was in this state 
of mind that he had his first heterosexual experience. After it he actually hated the prostitute. He gladly went away to war.

$\mathrm{He}$ usually did feel hate for a prostitute after coitus and sometimes said he never enjoyed intercourse with women as much as with men. At other times he claimed he preferred normal coitus, but was much afraid of venereal disease after once having contracted gonorrhea, and that he committed pederasty on both sexes and allowed fellatio merely because they entailed no danger of disease. He indulged in active homosexual acts about once a week. If his companion refused intercourse, he masturbated against him. Once he had trouble in arousing sexual feeling in a boy and to stimulate him started fellatio on him, but had a revulsion of feeling and quit. This attempt at fellatio had bothered his conscience a great deal. With that exception he had never taken the female rôle in homosexual intercourse. Taking the male rôle he considered permissible and he felt no remorse.

$\mathrm{He}$ had relations with his wife before they were married, and she became pregnant. She threatened suicide, and he married her out of pity to protect her good name. Another man, a lawyer whom he regarded as a better man than he, had also been paying her attention and he reasoned that since she had ceded readily to him she might have also to this superior man. Three months after the wedding a boy was born. The child resembled Purdy. He had only one real "love" coitus with his wife he said, the others were nothing more than relief of passion. Once he committed cunnilingus on her, and she committed much fellatio on him but refused to allow pederasty. When he got to feeling that his employer was giving him all the hardest jobs and he needed all his strength to make a living, he stopped sexual intercourse altogether. Then he began to suspect his wife of getting it elsewhere. He was sure his employer had relations with her and suspected him of sending a young man to board next door just to win his friendship and thus get the freedom of his home and opportunity to seduce his wife. And this young man he had considered his bosom friend. He wanted to murder all three of them, his wife and the two men. Doubts whether he was really the father of the boy haunted him again. 
He attributed his failing vitality to overwork, but one thing restored his self-confidence and made him feel equal to anything. Like Columbus, who discovered a new world, he also had the courage to do the impossible in that he succeeded in committing fellatio on himself. After that his spirits revived and he found he could do things in his work that he had previously thought impossible. (With every evidence of sincerity he insisted this incident was true.)

About a year before the present commitment he found a boarding place in the home of a poor widow with several children. She was "as homely as sin," but was a devoted mother to her children, and that aroused his sympathies. He felt like helping and protecting her as he should have done but did not do for his own mother when she was in identical circumstances. His interest in her began to arouse comment, and he hotly resented suspicions that he had sexual relations with her. Finally, however, his feelings toward her became erotic and he tried hard to seduce her. She refused even marriage because her children didn't like him, but she allowed him to caress and handle her. After many futile attempts he succeeding in making her erotic, and she hugged him and sniffed in her emotion. He realized she would not now resist him, and just at this moment of success he found himself absolutely impotent. "It was an awful blow. It showed up my weakness. I just went out of my head and raved.

"Afterwards I tried to reason out why I couldn't get an erection and I remembered how she had sniffed in her excitement. I decided that was what had sucked my strength. Then a neighbor came in to see me and urged me to go to a hospital. I recalled that his wife was sickly and so was a young man who boarded with them, and then I suddenly saw through it all, that he had been sniffing their strength away." In righteous indignation he beat the man up, and then felt so strong and elated in his victory that he got an erection. This was an opportunity to prove his masculinity to the widow and he attempted intercourse whether she would or no, but she was not in the mood this time. The police were called in, and he was taken to a psychopathic hospital. 
Fantasies: He had the usual delusions and hallucinations. "Other minds were influencing me. Some superior power was working on me and pushing me to do things against my will. The Catholics used influence on me to my hurt, they used witchcraft. That influence was beyond my control. When I was first brought to the hospital I ate my feces and drank my urine to prove I was brave and that I would not practice Catholicism. I'm a Jew." (Here he showed the common symbolization of the conflict of impulses as Catholics versus their religious opponents. Which party is the wicked one depends on the patient's own religious convictions. This man was further influenced by his unfortunate experience with his mother's confessor. Loyal Catholics like Lefferts make the Masons the devilish tempters who use influence on them to make them commit sexual perversions.) In addition people had tried to poison him, and he had felt electricity surge through him from his feet upwards, and his hair was pulled up. Another patient had put cocaine up his nose during his sleep and influenced him, and that had driven him insane.

He had been used as a tool for other people's purposes, they had hypnotized him and driven him insane and had him brought here to get evidence on him, for they wanted a scapegoat. $\mathrm{He}$ saw secret service agents in disguise all around him and suspected me of being one also, though at times he believed I was as I said a psychologist trying to help him. Once he told me he didn't want to talk with me, for he feared I would destroy his belief in his delusions and he preferred to keep them.

"The kernel of my trouble is that my strength and sex power have been sapped and it is something outside me that has done it." $\mathrm{He}$ was very busy trying to reason out just what had sucked his strength. One theory was that when struck by the train in his boyhood he "lost some of what a male is entitled to. I'm not the man my father was." But the sniffing seemed the likeliest method. The ward physician had a habit of sniffing and, being ignorant of the delusion, was much startled when one day the patient without warning spat copiously in his face. The doctor thought he had filled his mouth with water at the tap, but he reassured him later that it was only saliva. He realized now that 
people had been sniffing his strength away for a long time, but he had hit on a method of self-defense. If he sniffed back again, there was an interchange of strength, the balance of power remaining as before. After this discovery his conduct became more agreeable, for he could hold his own and consequently had nothing to fear.

He thought of his mother a good deal and wondered if she could have been raped when as a sixteen-year-old girl she had crossed the sea from Ireland to America. He remembered holding her down during her raving spells, and thought what a bad effect they would have on an embryo. Was it possible that he had been thus injured before birth?

"When I looked at a man who had a hypnotic eye I felt an erection and orgasm, but I had no idea of letting him go down on me. When he looked at me I said to myself I won't take it (the hypnotism), I won't swallow it (the host or saliva). I resisted, and he swallowed his host instead. When I see men swallow, I know they're afraid of what they see in other men's eyes. I can stare a person in the eye till they swallow their host, or saliva ; that's their weakness. It seems that I force them to." These fantasies disclose very obviously his resistance to fellatio, particularly towards taking the female rôle.

He suffered a good deal from headache. In a dream the pain was relieved by a man's committing fellatio on him. "The man said he was drawing it out of my brain. I felt a great relief in my forehead, then it went down my body and out my penis. I woke up and found I had an erection but no orgasm." A number of times he dreamed that both men and women masturbated him and committed fellatio on him.

A very vivid dream was of a horsehead on the end of a derrick. "The horse snuffed up oats and blew them into a box car for chickens to eat. Then I said to myself, 'Now I see through it all.' I felt an erection and orgasm and woke up blowing my breath out." This dream symbolizes his conscious fantasy that he could sniff up sex power (oats, seed, semen) from others to use in sexual intercourse. Horsehead and derrick represent his own head, penis and libido; box is the female 
genitals, and chicken is a slang term for a young woman. Both normal coitus and fellatio ideas are present in the dream.

Just before he was arrested and taken to hospital he used to sit a great deal on a magnifying lens, but though he puzzled over it he could not now remember why he did it. "That's where the insanity comes in; I can't recall the reason." (Protection against pederasty?)

General observations: He often had insight into mental condition and spoke of his strange sensations. "My mind wavers, and jumps from one subject to another. I remember having three ideas in it all at once. It seems like a piano board, the thoughts chase through it so much. I have trouble articulating. I'm like a ship without a rudder. I must be a nut. Sometimes I get into delusions. In the second talk with you I began to be able to follow one line of thought steadily. Before that my thoughts were all mixed up. I believe I am coming out of it. I can remember back pretty far now." Sometimes his memory became clouded.

His attitude toward me was variable. I told him he was mentally sick and that I was trying to help him get well. He responded at first, but in our fourth talk he said, "The first time I saw you, I felt I might confide in you. Now I'm getting suspicious of you." A month later he said, "I'll confess to you, a secret service man, an intelligence man, but I won't confess to a priest. I like your countenance, whoever you are." And again, "I've been kidded so much, fooled so much, that I feel fortunate to have someone like you to talk with and rely on in regard to my mental condition." These confidential moods alternated with periods of suspicion in which he began to see me about the grounds disguised in the garb of both sexes. "You're a slick one, Doc., you're a secret service man disguised. I'm well and I want to get out of here."

Occasionally he felt he was misunderstood and became very depressed and weepy. The paranoid traits appeared at such times. "When I get out of here, I'll be a bad man, I'll fight for my rights. People have used me as a tool, a stepping stone." Once he started to go to his old employers in town to demand an 
explanation of "what this is all about." His parole had to be taken back, and he was confined to a ward.

The masculine protest was shown by his letting his beard grow and wearing an army uniform. "I'm a man, I'm no mollycoddle, and I want to prove it." He demanded that I afford him opportunity for heterosexual intercourse, and when I refused, escaped to town in search of it, but was recaptured.

The greatest temptations of his life had been to murder his wife and the men he believed she had relations with, and to commit fellatio and cunnilingus. His greatest regrets were that he had not been able to have coitus with the widow when she was willing, and that he had done cunnilingus on his wife, and had once begun fellatio on a boy.

One day when he showed resistance toward me he said, "I keep things back from you because I don't want my belief in these things destroyed. I prefer my delusions. ("What is a delusion?") A false belief. They aren't false to me. I have faith in them. ("Why call them false then?") Because I was called insane. I've been driven insane by other people. They sent me here to get evidence on me, that's all. I don't know what they expect to find. They must have a fall guy, a goat. I don't want to get sane. I fear my son is not really mine, and the widow I was so fond of has negro blood because her son's arms are so very long." He became despondent and quarrelsome and got into fights with other patients, thinking they were women or myself in disguise.

In a fortnight he improved once more and his parole was restored. "I'm working my way out of this tangle, out of my delusions and hallucinations. It's as you say, it is real to the man himself, but it's all in his own mind just the same. I'm satisfied my trouble is all in my head and I feel I'm straightening it out. I feel I can find interesting work and earn my living. At first I couldn't believe you when you said the mind could get sick, I didn't realize it could. It seemed some phenomena superior to man. Now I see it's all in the mind. A man can be anything he has a desire to be, provided he has will power to back it up."

In another month he seemed fairly normal to his physician, and the latter allowed him to go on a Red Cross party to town. 
He slipped away from the guards in a theater and escaped. Months later a brother wrote to the hospital that the patient was getting along all right in freedom and requested that his name be stricken from the roll.

Occupational therapy: He consented at once to try bead work, but though interested was rather careless. He seemed to be more interested in having the instructor sit by him than in the work itself. He got more indifferent and as soon as parole of the grounds was granted him, stopped work altogether.

Physical examination: Medium type of skeleton with well developed muscles. Skin well nourished, perspires easily. Brown pigmentation on back. Hair of head gray and scanty. Body hair scanty. Genital hair normal in amount but submasculine in type. Genitalia normal. Heart regular but rapid. Extremities cold and slightly blue. Eyes protrude. Reflexes normal. Thyroid gland slightly palpable.

\section{Endocrine diagnosis: Hyperthyroidism.}

Glandular therapy: He went through the tests which established the endocrine diagnosis, but escaped before any real glandular therapy was begun.

Mental diagnosis: Schizophrenia paranoid. Not only were his improper sexual impulses projected onto other people but, as the years went on, he built up a somewhat systematized structure of persecution in other matters besides sexual. The delusions themselves did not change so much as did his belief in their reality. At times he had considerable insight as shown by such a remark as, "I realize I was nutty, and I may be yet at periods."

It is easy to trace the effect that his mother incest impulse had on his life. His father's brutal punishments and his mother's attempt to shield him probably helped to fix his libido on her in the first place. He felt resistance toward taking his father's place in the family after the latter's death, and had a revulsion of feeling toward her, seeming to prefer the father image. His suffering when during her raving spells he had to hold her on the floor was perhaps not entirely due to her unlovely condition. $\mathrm{He}$ was quite ready to suspect her of illicit relations with the priest. His fear of infecting her with gonorrhea was hardly justified. His incest fears drove him to abandon her even though he knew 
it was an unworthy thing to do, and his remorse over this act followed him all his life. An exaggerated recoil from incest can cause a certain amount of resistance toward the whole sex, and he found little satisfaction in heterosexual intercourse, usually preferring males, though he rationalized this tendency as due to fear of venereal disease. In marriage he had little pleasure, and said there had been only one real "love" coitus. Something spoiled the others. Finally he became somewhat impotent and stopped relations entirely. The widow attracted him in spite of being "homely as sin," because she was a devoted mother, and he likened her to his own mother and resented insinuations that there was anything erotic in their companionship. Later when he gave way to his erotic impulses he found himself suddenly impotent at the moment of opportunity. In the hospital he had fantasies of his mother's having been raped while emigrating to America.

In homosexual matters he rationalized the male rôle as permissible. His cravings to take the female rôle were sometimes recognized and resisted, and sometimes repressed and projected.

\section{QUITNER}

History: He was a petty officer in the navy thirty-eight years old, and was serving his fourth enlistment when sent to hospital. He was one of eight children and was born in Hungary. When still a little child the family emigrated to America, and he spent his boyhood and youth in a great city. He attended school from the ages of six to eleven and reached only the fourth grade. He didn't do well in his studies and felt humiliated when other children surpassed him. He nearly cried with shame. Not only in mind but also in body he felt inferior and was much ashamed of his small frame and delicate bones.

After leaving school he worked for two years as a cash boy in a big store, but quit because people teased him. Other jobs didn't last long. He couldn't adjust and gave them up. He tried night school but couldn't get on there either. At nineteen he left home and wandered west to see the world. After he tired of a job or a city he moved on to another. He reached San Francisco 
when he was twenty-two and enlisted in the navy. Between enlistments he roamed about on land from job to job.

He got on all right in the navy until the fourth enlistment, when it was noticed he was queer, but he still did his work satisfactorily. He talked much about religion and spiritualism and knelt like a fire worshiper making obeisance to the sun or to lighted cigarets. He said he heard voices as if coming from a telephone receiver, and believed that God spoke through him. Finally he received an order from God via his mother that the ship should change its course, and without securing permission he invaded the captain's cabin and delivered the message to him. To his great indignation he was arrested and sent to hospital.

$\mathrm{He}$ was perfectly oriented and could remember well. $\mathrm{He}$ declared he wasn't crazy and that he could think even better than formerly. He had hallucinations and delusions of persecution, was very suspicious, and had no insight whatever. He was tense and emotional and very talkative.

His suspicious antagonism to the doctors was so keen that he could not be admitted to the endocrine ward for nearly eight months. By that time he had quieted down very much, and while still insisting that he had not been insane and that it was a dirty trick to shut him up, he behaved well and was willing to talk courteously with anyone.

Sex life: He made no mention of masturbation. When ten years old he had been warned to beware of men who might try to commit pederasty on him, and he saw two negro boys in the act. At twelve he had his first heterosexual experience. When eighteen he fell in love with a girl, but his sense of inferiority caused him to step aside to allow her to get some superior fellow with better prospects. Then he began his wanderings.

Later in life he had relations with a widow and helped to clothe her child. The act of coitus he had reduced to a fine art. Perversions he denied.

Fantasies: He began hearing voices about a year before the incident with the captain, and at first they were insulting. They were like spirits and they knew all his past, all his sins. Finally he made peace with them by confessing and acknowledging his sins to them, and then they ceased bothering him and became 
friendly. "If Garland and Engel would do this instead of fighting the spirits, they would be all right. The spirits are company. It's impossible to be lonely when you can talk with them. I answer them noiselessly by making silent movements in my throat and larynx. Like a medium I get messages from God as over a telephone. He is interested in me like a father in his son. Father, mother, son, that is religion. At first the voices were insulting and sounded as if coming from some distance outside me, but I coaxed them closer and closer till now they're inside my head completely.

"I've always been able to mimic girls and women. I've gone to fancy dress balls disguised as a girl and fooled everyone. (For my benefit he mimicked a woman very well, and it was evident that he enjoyed doing it immensely.) But it's dangerous to act ladylike, for some fellows jump to the conclusion that you're a pervert. In the navy I was always on guard against other men's suspecting me of being a pervert and for that reason I kept alone some. When a fellow feels lonely it's a comfort and a pleasure to hear his own thoughts as you call them, to hear these spirits. They talk to each other and I listen, or I join in and talk with them."

When told these spirits were splits of his own mind and that he should try to reunite them, the prospect didn't attract him at all. "I prefer to keep them as they are, they're so comforting and interesting. I don't want any change. I have seven of these spirits inside me. They are like my children. I wouldn't want to lose them any more than a father would wish his children to die. Besides, I don't see how they can be splits of my own mind for sometimes I'm sure they tell me interesting things that I never knew before."

General observations: The first day he entered my office he looked around suspiciously and admitted he feared a dictaphone was secreted somewhere. He began the talk by boasting of his adaptability, saying he could pass as tough or refined at will. $\mathrm{He}$ had always been much interested in religions and believed they originated in fear; fear first, then worship of the thing feared (recall his worship of the lighted cigaret, a frequent potent penis symbol). 
In the following interviews he aired lengthy grievances about his detention and mistreatment. To contradict or reason with him led to an unending maze of argument in which he delighted. I finally stopped it short and said I was more interested in his ow shoughts than in what other people had done to him. He reproached me for not taking more interest in his grievances. "If I had been a pretty girl, you'd have waked up, straightened your back, and said, 'Miss Quitner, we'll look into this and see what can be done.' ("But you wouldn't want to be treated like a girl.") Yes I would. ("That would be favoritism, not justice.") Then I want favoritism. I'm looking out for number one. I want sympathy.

"In tough neighborhoods one has to be tough because if one is too pleasant and soft, they may take you for a fruiter (fellationist) or a bushwhacker (cunnilinguist). Such fellows are soft and easy and dreamy like Engel. I found out in the navy that there were two classes of men, those who stood up for their rights and those who gave in. (It was clear that he had trained himself to be touchy and instantly to resent with force any slight, an overcompensation for feelings of inferiority and fear of being considered a pervert. Ulster in his restlessness struck him one day, and he reacted exaggeratedly, attacking Ulster so violently that he broke one of his own fingers.) Middle-aged pederasts are called Turks. They go insane. They suffer from it more than the boy they do it to. It's dangerous on board ship for boys. I used to warn them of the danger, and the Turks in revenge made things disagreeable for me."

He showed some antipathy to the women nurses and the occupational therapist, and was exceedingly conceited, believing he knew more than the physicians. This made psychoanalytic work with him difficult. He already was aware, however, that children had attributes of both sexes and must develop those of their own sex, neglecting those of the other sex. This he had striven to do. He was intelligent enough to grasp the conception of mental mechanisms well, but he felt reluctant to give up his dearly loved spirit voices. He even wrote a poem about them which he called Babies in Fairyland. 
He said he wanted to go away off into the wilds after regaining his freedom, so that he wouldn't get locked up again. He came to see clearly that no one had interfered with him so long as his spirit beliefs hadn't affected his behavior or led him to do forbidden things like forcing himself on the captain. $\mathrm{He}$ had previously argued that if belief in spirit voices was sufficient grounds for incarceration in a hospital for the insane, why weren't Sir Oliver Lodge and other spiritualists locked up too. He learned to see that if he behaved in a manner acceptable to his fellowmen and could do his work, no one would bother much about his beliefs.

Occupational therapy: $\mathrm{He}$ was only mildly interested but could do good work. He preferred arguments to basket weaving.

Physical examination: Slender type of skeleton. Skin smooth, dark brown over entire body. Hypertrichosis. Hyperhidrosis. Extreme sensitivity to heat and electricity. Front teeth protrude outward from alveolar process. Reflexes hyperactive. Fine tremor of fingers. Eyes protrude, pupils dilated and active. Heart irregular. Thyroid gland slightly enlarged.

Endocrine diagnosis: Hyperthyroidism with associated pituitary dysfunction.

Glandular therapy: Thyroid rather increased his nervousness and argumentativeness. Suprarenal had a better effect.

Four months later: A month previous to my return he had been discharged as a social recovery from dementia precox. The records stated that his physical health and his mood improved steadily. Finally no psychotic symptoms were seen. He said his behavior during his insanity had been like that of a drunken man, he wasn't responsible for his acts.

Mental diagnosis: Schizophrenia paranoid. His long struggle with the feminine side of his nature is evident. The insulting voices were without doubt his projected perverse cravings. After he had confessed his sins, the voices lost their disturbing quality and became a means of recreation inside his own head, or in other words the perverse cravings were again repressed deeper into the unconscious. But the habit of projection kept alive a paranoid fear of hostility from mankind in general. 
This had largely disappeared before he entered the endocrine ward. It is doubtful whether the schizophrenic habit did entirely cease, but he was at least cunning enough to conceal it from the physicians and obtain his discharge.

\section{RIEGEL}

History: He was a chunky, ill-proportioned sailor twentysix years old. He denied there was any mental disease in his family, but said his mother was nervous and cranky and annoyed him a great deal. He went to school from eight to sixteen years of age and reached the eighth grade. He didn't get on well there; the teachers were cranky and didn't want to teach him anything, and he had to learn all by himself. He didn't get on any better at home; for everybody wanted to be the boss. He liked his father and brothers better than his mother and sisters. His mother was too cranky. She called him a lazy loafer and other worse names.

After leaving school he worked in factories and machine shops, seldom staying long in one place. The other men wouldn't show him how, and then the foremen would fire him, or he would get into a fight with the other men or be laid off when work was slack. The poor workingman he declared, was oppressed by every class, by the farmers, the rich, the municipal employees, everybody. He had expected big jobs and big money and got only disappointment. The fault was always somebody else's. He felt everyone was against him.

When in imminent danger of being drafted into the army he enlisted in the navy and he considered the war and the draft a fresh imposition. In the navy he had a terrible time trying to adjust. Eastern boys made fun of western boys like himself, they guyed him on his short stature and clumsiness and table manners. He felt helpless and inferior and that everyone was down on him, and he reacted with hate and anger.

A year later he was removed from duty, as he was unable to carry out simple orders. He had been doing very unsatisfactory work as a messman. He was tense, nervous, and untidy, and defecated in his clothes. He thought the other fellows had it in 
for him and were talking about him behind his back. He reached this hospital after some months and believed he had been sent here only for discharge. He saw nothing wrong with his mind, but sometimes it got sleepy, and his legs felt weak.

Sex life: His attitude was very resistive, but I succeeded in getting some information. He admitted masturbation but wouldn't tell how often. He had always been bashful and unsuccessful with girls. He had never had a best girl, that was all damn foolishness. A wife was nothing but a moneysucker. $\mathrm{He}$ had never danced, he was too clumsy. He had never had heterosexual intercourse, nor committed perversions.

His wet dreams were of accidents to which he was a spectator only. Wagons and automobiles ran away, tipped over, and broke the legs of the passengers who were always men. There was much blood. These dreams were not unpleasant. Another typical dream was of work, work, working in the shop. He denied dreaming of women.

He had not been able to get an orgasm since entering the hospital.

Fantasies: He sometimes seemed lost in thought, and smiled or chuckled to himself, but he never would divulge what amused him. Often he looked furtively at other patients and then went off into silent glee as if ridiculing them. Any laughter he heard on the ward he immediately attributed to himself and swore furiously under his breath. The occupational therapist frequently heard him muttering to himself, and once he exclaimed angrily to her, "If you call me a fool, I'll be damned if I'll work for you," when she had said nothing at all. He went away scowling and would not work for a couple of days.

In answer to questions he denied seeing visions or hearing voices or feeling that electricity or any outside force or influence was being used on him. ("Do you think other people are combining in a plan to hurt you?") "Yes, by talking about me. ("What do they say?") Gee, I don't know myself!"

General observations: He had a great sense of grievance and felt that other people were imposing on him. He was very self-conscious and constantly on the defensive, looking for slights. Any friendly advances were rudely rebuffed, for he suspected 
some hostile motive or intention to ridicule, and muttered and glowered hatefully. I have never seen more hate in a human face than in his.

"I'm not as strong as I used to be. My thoughts are getting slower. I don't feel like moving myself much. I can't think as fast as I used to. I've no appetite and I feel lazy. I don't like this climate. I can't get braced up. I worried myself out, working in the machine shop. You get to be an old man in a short while. ("Why don't you mingle with the other patients?") They're from other cities, and I don't know what to say to them. They don't want me around. They go on their way, and I go on mine. You're from another state, and so you're not easy to talk to.

"People don't care about me; they have enough to do to take care of themselves. In the navy one fellow called me short, and the others laughed (intense emotion). I've always been guyed about being short. A navy chief had it in for me because I was from the west. He gave me extra work. They made fun of westerners, of our table manners and the way we looked. I felt the other fellows came from better families. Workmen like me have a hard time. When work is unsteady the money soon goes. Some people have money already and don't have to worry. Other people get better chances than I do. You can't help me, and I can't talk with you, because you're not a shop worker like me. You loaf around here and do no work. If I was as well fixed as you I'd feel good too. You're not in my class. I want to keep to my class. You like women, you're dressed that way, you're not a bad looking fellow."

Quizzing him on his sex life drove him into such a fury of hate that I half expected him to leap at my throat. For a month I paid no attention to him, but every time I entered the ward he glared at me ferociously. However, he never actually offered physical violence to anybody. Through gifts of candy he became sufficiently mollified so that $I$ attempted the Terman intelligence test. All went well until he began to fail on the harder questions and realized he was failing. He got so angry that he did poorly on some problems that I felt sure he could have solved if he had 
not been so emotionally upset. Throughout life this has seemed to be his customary reaction to his failures, and he projected the blame on other people. His mental age was twelve years, intelligence quotient 75 per cent., that is, low average intelligence, nearly a moron.

Occupational therapy: He began without urging but was handicapped by his self-consciousness. He was shy about asking questions and when things went wrong went to pieces. His work showed no improvement but was of fair quality. Sometimes he was so ugly that the instructor left him alone.

Physical examination: Short in stature, heavy type, large head and neck. Skin dry and covered with fine white scars and a papular eruption. Normal distribution of hair about genitals with moderate amount over chest. Beard heavy. Genitalia normal. Heart normal. Eyes very sensitive to light. Deep reflexes markedly hyperactive with wide extensions and reinforcements.

Endocrine diagnosis: Submyxedema.

Glandular therapy: Thyroid made him somewhat more active physically. Nurses and attendants said he seemed pleasanter and more contented and didn't look so mean or mutter curses as before. One of them noticed he acted apprehensive and looked back over his shoulder, but he said people didn't bother him as much as they used to. Then he began to masturbate at every opportunity and became depressed.

Four months later: He had been transferred to a state hospital nearer his home. The record stated he had improved remarkably. He stopped masturbation, lost his fearfulness, and became pleasant and courteous. His mind seemed clear, and he paid attention to his personal appearance. When asked why he was so much better humored he replied, "Nobody bothers me now. That's why I don't swear and curse as before."

Mental diagnosis: Schizophrenia paranoid. He was too suspicious and resistant for one to learn much of his sexual difficulties, but since he projected his more apparent difficulties of every day life onto others, it is more than probable that he did the same with his deeper sexual troubles. That he had them 
was shown by his ill success with girls and hatred of them and by his resistance towards his mother and sisters. No doubt he projected hostile physical and sexual wishes onto the environment, for as he recovered he admitted that people didn't bother him so much and finally didn't bother him at all. The change was entirely within him, his environment was not altered. Anal erotic and sadistic cravings were clearly revealed by his pleasant wet dreams of accidents, broken legs and blood, in which he was an interested spectator.

\section{SABIN}

History: He was a man thirty-six years old, slow and quiet and well-behaved. He had lived an uneventful life on a southern farm, sometimes clerking in stores in the winter, until he was twenty-one. Then he enlisted in the army to see the world and spent his five-year enlistment in two barracks. He didn't leave one of them for six months and his comrades asked him why he didn't bring his coffin in. During the service he married, his wife remaining in her parents' home. They had one child, a son. Apparently he was already slow and retarded before his discharge from the army. He worked as a visiting nurse in Baltimore, catheterizing prostate cases, and then was employed as a choreman in Shepherd and Enoch Pratt Hospital. After a month he was fired. He tried for one day to find another job and then, recalling how kindly the patients were treated at Pratt Hospital, decided the easiest thing to do was to enter an insane hospital for protection. He lost heart easily, he said. Accordingly he presented himself at one of the Maryland state hospitals and requested that he be received. He screwed up his lip and stared into the distance in an attempt to look crazy. They told him they saw nothing the matter with him but would take him if he so desired. This account is the patient's own version.

$\mathrm{He}$ was hazy whether he spent three or five years in that hospital. While there he worked on the farm. One day an attendant told him he saw no use in a man as young and as well as he staying there, and he ran away. At first he worked on a farm not many miles away, but fearing he might be discovered he left and came to Washington and hired out as a garbage wagoner. 
It seems that even this was too much for him to do without surveillance, for after seven months he was arrested and taken to a hospital with body and clothes in filthy condition, and physically much run down. He said he had worked long hours and cooked his own meals in a vacant lot. On admission to St. Elizabeths he showed considerable mental deterioration.

Sex life: As a child he slept between his parents in the same bed, but had no recollections of having seen them in coitus. At puberty he got an erection on seeing his mother accidentally expose her leg, and he hid and masturbated. She caught him at it and whipped him. The small negro boys of the vicinity performed perverse acts and offered themselves to the white boys for five or ten cents. His father had a negro boy working for him whom he had "bought out of jail" in which he had been incarcerated for attempting coitus on his mother (according to patient). The patient tried pederasty on this boy and, failing, had the boy commit fellatio on him. His father found them doing it and whipped them. Never again did he commit a perversion.

His first coitus was at sixteen with a married second cousin who invited him. This happened several times. At nineteen he began going with prostitutes. At twenty he again saw his mother unwittingly expose herself and got an erection. Not long after, he returned one night unexpectedly and surprised his parents in intercourse. This seemed to have been a trauma. He felt that he didn't belong there any longer and never felt at home again. It was then he joined the army. He claimed not to have masturbated more than a dozen times in his life, but he had coitus about once a week when possible. While in the army he married, and enjoyed coitus with his wife until after the birth of their child. She was then apathetic, and he lost interest and left her. $\mathrm{He}$ denied ever having been impotent, but his fantasies were full of means to avoid becoming so. During the last few years spent in hospitals and garbage gathering he had had no intercourse, nor had he masturbated. There was no desire. His wet dreams were of heterosexual intercourse.

$\mathrm{He}$ used to be pretty passionate he said, and lust and longing for masturbation made life a misery. Giving in to perversions 
would only increase desire. He felt that way after fellatio with the negro boy, but he never succumbed again.

Fantasies: The first intelligible fantasy he gave evidence of was concerning hair. To grow long hair and leave it uncut was necessary in order to excel in health and potency. If a man cut his hair while a woman let hers grow, she became the stronger and sucked his strength. He grew a beard in order to look like his father who had been a hairy man and had always worn a beard.

Sometimes the voices mentioned birth, sucking a cow, fellatio, or son-of-a-bitch, and he thought persons left an influence behind in every place they had been. The influences left behind by old men bothered him particularly.

When the attendant tried to get him to help in the ward work, the voices objected and said the attendant was supposed to do it himself.

During a moderately dull period in the fourth month he suddenly divulged a mass of sexual fantasies, all of them concerned with the maintenance of potency. "If a father has coitus: with the mother while he thinks of a living child, he takes strength' out of the child and puts it into the mother. When the mother gets old and her sexual organs become flabby, that makes the son weak, for there is a sexual sympathy between mother and son. The son should then leave home. My father wanted me to get out. That was probably the reason. If parents still have intercourse after they have ceased to be able to beget children, it sucks the strength of their son. It was using up my manhood. Before I caught them at coitus I was sucking their strength. Afterwards I lost strength because they sucked mine. Probably a mother, when she and the father get old and sexually weak and their son is passionate and ready to go with girls, goes to the house of prostitution ahead of her son, disguises herself with paint and short dresses so he doesn't recognize her, and has intercourse with him, getting his passion to bolster up her own so she can use it with the father. My parents were reported dead and yet I saw my father off on the lawn a few days ago, so my mother is probably alive too. I have no doubt she has had intercourse with me to get my passion away. She pretended 
death just to fool me; I don't understand it. If the father has intercourse with the mother and doesn't make her pregnant, it harms their living child, makes him weak, makes him want to go back into her sexual organs and be reborn. All children have sexual feelings towards their parents."

"If in a group of thirteen men (like my little group in the army) only four indulge in coitus and the other nine go without, the four suck the strength of the nine. When I married, my comrades supported me with their strength and my wife's family supported her, but her sisters got fellows of their own and lost interest, and she got less passionate and didn't care whether she took me or not. I felt as if I were masturbating in her; I might as well have done it out the window. Then I left her. It weakens a man if the woman doesn't respond and breed. When passion rises between buddies until one gets too strong, he seeks a girl and absorbs the other fellow's strength. If a man should receive another fellow in his mouth, his ear, his anus, or his fist, but people don't allow that, those parts of his body would feel like repeating the act at the same time the next week. That's the way I felt after the nigger committed fellatio on me, but I never did such a thing again."

"Once I worked on the farm of a man who was absent. His wife was sexually old and worn out, and I got to feeling that way too. You see I was taking his place. I had to get out. You don't want a woman whose strength has been used up by some other man, for it weakens you."

When he was still duller, he talked of having recently had both active and passive pederasty hallucinations, of girls through intercourse turning into males, of mothers making penises out of their skin and flesh and using them for intercourse with their sons, of boys whose genitals were alternately male and female, of a man he saw naked in the hospital bathroom who had big teats and a little penis and claimed to have been his wife, and of tables without heads which grew hair. "I've a mind to get a gal and have intercourse with her till I turn her into a boy."

General observations: On admission he wore long hair and a full beard, and objected to having the beard removed and his mustache and hair trimmed. He wanted all the hair possible, 
because it meant strength both physical and mental. His mind seemed deteriorated and much of his talk was unintelligible. $\mathrm{He}$ was quiet and apparently emotionless, sitting all day long in a chair. His expression was dull; he spoke slowly and seemed to have difficulty in moving his jaw. A sample of his talk is, "I'll say it's glass that wheels itself and begets itself and lets you hear and then collects itself back into line."

To everyone's surprise his mind cleared after a few weeks and he seemed quite normal. He was interested in everything, was quick to join in any conversation and became facetious and witty in a country smart Alec way. When confronted with what he had said in the previous dull period, he exclaimed that it didn't make any sense. He said also that he no longer had any queer ideas. In three weeks he went into another depression, looked dull and apathetic, heard voices and talked nonsense. Any noise became a speaking voice to him, as the purr of a radiator, or squeaking footsteps, and he would report to me what they said. Sometimes voices shouted indistinctly in his ear.

In two weeks he was alert again and said, "Those voices come when I feel sick, or bilious, or have indigestion, and leave when I feel good." These alert and dull periods lasting from two or three days to a week or two alternated continually. During the dull periods he could play a slow but good game of checkers and continue slowly his leather pressing occupational work. When dull he sometimes used clang associations, and he always had trouble moving his jaw to speak. He also complained of feeling weak and tired and not being able to remember well.

Occupational therapy: After hesitating three days he began to work and continued it without interruption. In his depressed periods he did poorer work than in his normal ones. He preferred leather pressing, showed good judgment and artistic feeling and improved steadily. He originated some of his designs.

Physical examination: Large type of skeleton. Powerful muscular development. No deformities. Skin soft and pliable but shows localized hyperaemias or "flushings." Perspires very easily over hairy parts. Face is notably plethoric. Hair, normal distribution over chest and genital region. Genitalia normal. 
Heart normal. Superficial reflexes all present. Deep reflexes slightly hyperactive.

Endocrine diagnosis: Hypoadrenia.

Glandular therapy: None. He was transferred to another hospital before treatment could be begun.

Mental diagnosis: Schizophrenia with projection and features of circular insanity.

One can see that this man had long had an incestuous love for his mother, when one considers his getting erections at seeing her legs as a boy and adolescent, his distress following his finding her in coitus with his father, his resistance towards his wife after she became the mother of a son, his present fantasies of incest and impotence and his attempt to look hairy and virile like his father. The long fear of impotence was probably caused by the realization that his cravings were directed toward a forbidden object. Homosexual cravings were also present.

His alternating periods of happy normality and depressed dullness and confusion were like quick-changing circular insanity. His different levels of sexual thought are interesting. In his clear, alert periods his sex attitude seemed fairly normal, in moderate depressions he was in the Edipus-homosexual stage, in deep depressions his thinking became archaic with bisexual monsters and metamorphoses.

\section{ToccI}

History: He was a wiry, delicately built little Italian with almost feminine agility and grace, but surprisingly strong. His age was twenty-five. In Italy he had only three years of schooling, after which he worked as a farm laborer, tailor and shoemaker. At seventeen he came to America to see the world, and wandered from city to city working as a shoemaker. He went to night school to learn English but still spoke it so badly that he was very hard to understand. He felt lonely and unhappy in this country. "I was sorry to be alone, far away from my family, and disturbed not to see my people. They told me not to worry but I worried all the time. If I got sick, who would take care of me?" He suffered much from headaches. 
He was probably drafted into the army. It was difficult for him to adjust to the new conditions. He deserted and was found wandering in a confused state of mind. He felt very tired after doing any work and was much worried over voices in his ear that sounded as if coming from a telephone receiver. They were from bad people and said bad things and called him insulting names.

In this hospital he was catatonic and showed waxy flexibility. He complained that he couldn't think and that voices persecuted him. If not guided he bumped into objects when walking. In the fourth month he grew excited and went naked, then again became catatonic. From then on, depressions alternated with manic periods, and he often attacked other patients. $\mathrm{He}$ was grandiose at times and decorated himself. He had spent nearly two years in the hospital before entering the endocrine ward.

Sex life: Another boy taught him how to masturbate, but he wouldn't say how much he had indulged. He said it was not good for one. He never had had heterosexual intercourse, because he feared disease and if he got sick there was nobody to care for him or look after him, for he was all alone. He never had had girl friends. He intended to marry when he was old enough. When he was seventeen a widow wanted to marry him, but friends warned him he was too young. Wet dreams frightened him very much; he had had them nearly every night at one time. A druggist, however, told him not to worry and said they wouldn't hurt him, and gave him some pills. In the hospital he had them about twice a week, but they didn't worry him. No dreams accompanied them. He denied perversions and showed disgust at the mention of them.

Fantasies: At first the voices were obnoxious but later they were of good people and said good things. Usually he could make out no voices at all, only a faint ringing in his ears. $\mathrm{He}$ said he liked to think of good things, good people, good houses and good cities.

Once he thought all his family were here in the hospital, and that he had seen his mother when he went to bed and she had talked with him. He had hoped he would see her again the 
coming night. He called some of the middle-aged patients uncle and called younger men cousin.

He dreamed of good years, good business, good people and of talking with them. One dream was of two brothers jealous of each other. Another was of one man against all of the family, and of a private in the army. Some dreams seemed to be reminiscences of his past life, such as reading and writing in a library, visiting shoe shops, and planting grain.

General observations: He said he didn't know why he was brought here, but perhaps it was because he was sick and cold. When he felt better, he was not so cold. He complained of sweaty hands and tied rings of string around his fingers and forearms to prevent the sweating.

The most striking aspect of his behavior was his rapid swings from depression to elation. On an average the periods lasted only one day, though fairly frequently there was an intermediate period of one day in which he was quiet but worked steadily.

In his depressions he usually sat motionless with eyes closed and refused to eat. Sometimes he huddled with a coat over his head, complaining that his head was cold. Often he stood in one place for hours. If asked how he felt he might answer, "All right," or "I don't feel good."

In the intermediate stages he sat staring gloomily into space, or did occupational work without speaking to anyone.

In his manic phrase he ranged from happy busyness to great elation when he wanted to have a finger in every pie and run everything and everybody. With peals of laughter he would slap me on the back or put his arm around my waist and whirl me down the room, or leap up like a cat to intercept the basketball in midair and scramble wildly after it when it rolled under the beds. He took the other patients' work away from them, stole their food, and refused to give up his tools when it was time to quit. The other patients stopped playing cards with him, for he insisted on taking every trick no matter what card he played.

He was frugal and reiterated, "I must save." His clothes were so stuffed with trash he had saved that he often looked like a circus clown. He was affectionate and constantly insisted on shaking or kissing one's hand. But stubbornness and wilfulness 
were his most prominent traits; he wanted what he wanted when he wanted it, and nothing but superior force would make him desist. He seemed to have no conception of adjusting his wishes to those of others.

One physical examination had to be given up because he was so excitable and afraid, and in the second attempt he showed much fear of the rubber hammer used to test reflexes, and reacted exaggeratedly.

Occupational therapy: He took hold of the work with alacrity and quickly learned to do all branches of it well. His wilfulness made him impatient of instruction and he went on according to his own ideas. In his elated periods he worked rapidly and even grabbed other patients' work away from them in order to "help" them. In his depressions he did no work at all. In the occasional intermediate periods he worked steadily and quietly.

Physical examination: Slender type of skeleton, but well muscled. Skin normal. Small amount of hair on chest but normal in genital region. Genitalia normal. Heart rapid. Pupils dilated. Reflexes were active. Psychomotor activity pronounced.

Endocrine diagnosis: Hypoadrenia.

Glandular therapy: He was fed suprarenal gland. At first he showed a marked improvement. Instead of having a depression every day or so, he would remain elated for several days at a time. When the depressions recurred they lasted barely a half day and were not so deep but what he could work throughout them. The attendant said that during them his skin was cold and clammy, and immediately after them his face was pigmented brownish, and then the color gradually faded to normal.

By the end of six weeks the good effects of glandular feeding had begun to wear off. The depressions grew somewhat more frequent and deeper, and he began once more to refuse food.

Four months later: He seemed much the same. The depressions and elations now lasted about a fortnight each. When depressed he often became ugly and attacked other patients viciously, trying to choke them. He had to be confined in an undesirable ward.

Mental diagnosis: Schizophrenia with projection and features of circular insanity. The projection of his bad impulses 
into insulting voices was schizophrenia. He had partially succeeded in repressing them for he seldom heard them any longer, but the schizophrenic habit persisted in his fantasying good people and good thoughts. Probably the depressions were due to the undesired unconscious cravings striving to gain control of his conscious thinking. At first the glandular feeding helped to prevent this unwelcome eruption, but the effects gradually wore off.

He was clearly an undeveloped personality. The homesickness and lack of self-confidence and independence showed his fixation on the family. At seventeen he even considered marrying an older woman, a mother substitute. In his bedtime fantasies his mother came and talked to him.

\section{ULSTER}

History: He was a restless, unkempt, unhappy fellow of twenty-three. A social worker visited his home and reported it as comfortable and decent, and that there seemed to be no abnormality, alcoholism or degeneracy in the family. His sister said he had been a normal boy, healthy, well-liked, athletic and got on well in school. His own version was that he had always been up against it, that he was bashful and couldn't get used to strangers, and preferred to stay at home rather than associate with other boys and girls.

He said he attended school irregularly and finished the sixth grade. Then he worked in a shipyard and made good wages, paying his own board and saving money, though too fond of shooting craps. He was drafted into the army.

His army record stated he was put in disgrace by his comrades and became listless and depressed. It was thought best to reclassify him in order to give him another chance in a new unit. But he grew worse and was put in hospital instead, and eventually reached St. Elizabeths.

Sex life: He talked incessantly in a disjointed manner during all his waking hours, and usually one could not break this stream of ideas and get him to answer a question unless one shook him by the shoulder or give him some other sharp stimulus. 
Consequently it was difficult to get any information from him except by culling it out of his stream of talk, and one could not be certain what was fact and what, was fantasy. Under this heading I have given only what I believed was fact.

He had much sexual curiosity, but his bashfulness prevented him from seeking experience. In France he first tried heterosexual intercourse, but did not satisfy himself. "I've never had a good coitus or seen a vulva. My penis slipped out. The girls said it was too small (his genitalia were normal). Boys said it was too small too."

He submitted to pederasty by other soldiers, and that must have been the cause of his disgrace among his comrades. Once he said he had committed fellatio also, but denied it in the next breath.

General observations: In our first talk I asked what he was here for. "I'm sick in the guts, in the stomach, and spine. ("Are you getting any better?") I don't think so. This is a state prison or a reformatory." (I explained it was a hospital for mental disease, and that he was being kept here only because his mind was sick. "Do you believe your mind is sick?") Yes, it always has been. This place is full of nuts. They fatten you up. $\mathrm{He}$ wants to get fat and go home and get an automobile. $\mathrm{He}$ was afraid he was going to get shot. He wants to get home. He's supposed to be a white rat. I heard that. He wants to borrow a couple of hundred dollars to get home with, this kid does. This world is coming to an end. I hear voices all the time. Catholics and Masons. He ought to fall under a train for being a Catholic. I'm a clean white kid, I never did anybody dirty. Father supposed to be a Catholic, mother too. I guess I'm only afraid to fight with bare fists. I fought in France with boxing gloves. I want to go home. Being afraid of people. This kid wants to be rich. They won't tell him nothing. He's against the Masons and Knights of Columbus and everybody. This kid would do anybody a favor. (He spies a calendar with a picture of a pretty girl.) Have coitus with her, with everybody in the world. I earned thirty dollars a week in the shipyard. He wants an automobile to ride around in. Spiteful devil, me. 
$\mathrm{He}$ (indicating the analyst) says he likes you, and all he does is write. He won't lend you money or buy an automobile. I'd pay you back. No, just jump overboard."

This talk was typical of those that followed except that later he spoke much more freely on sex subjects. The pleas for money, home and automobile, however, were never omitted in any interview. This first talk disclosed his main preoccupations. $\mathrm{He}$ had a feeling of sin and remorse and felt he ought to be punished for it or even commit suicide, and feared others would punish or kill him. He said that on the trip from France to St. Elizabeths he thought of throwing himself or being thrown under a train or into the sea. Then tearfully he protested his innocence and begged to be allowed to go home and to be given a motorcar to sport around in. His sense of guilt centered about sexual perversions, deceitfulness and cowardice. The conflict between good and bad impulses was dramatized as the familiar hostility between Catholics and Masons.

In later interviews he said, "These fellows pick on you. They pick out your tits. I've never seen a woman's genitals in my life. He wants to see a woman bare-naked. I never did see fellatio committed. The world would come to an end. They say it's coming to an end. Get rid of his dirty thoughts. His mother (she was dead) knows everything he does. Jerking off in the street. This kid knows he's a four-flusher, he wants to get washed out. My penis is burning up in my heart. The blood is being sucked out of his heart. (He looks at his face in a mirror and whimpers.) Dirt and filth. His tits, hearts, testes, eyes are picked out. Burn the tits right out of him. Do cunnilingus and allow fellatio. Put it in the paper (apropos of my steady writing). The devil is female and gives dirty thoughts. The voices suck the blood out of you by talking to you. They tell me to commit fellatio. Masturbate your father. They're bleeding me to death. They have no right to. If anybody called him a rat or accused him of mother incest or fellatio, they'd cut his eyes out (symbolic castration).

"Please don't suck his tits. ("I'm not doing it.") It feels that way. They burn. You ought not to suck his tits. You're 
sucking my tits and my eyes. They burn. (He tries to force his left eye out of its socket with his finger. I expostulate and stop him.) He might as well help it along if they are going to suck his eyes out anyway. He wants the dirt cleaned out of his heart, whitewashed and go home. Whitewash tits, penis, vulva, anything in your body. Give him a new penis and testes and guts and kidneys. Wash out his kidneys. He wants to get rid of his dirty thoughts. He wants new genitals. He wants to get married.

" $\mathrm{He}$ sucks tits, this kid does. No, you mustn't think that dirt. Jump overboard! jump overboard! (The revolt against the improper craving can be plainly seen here with the suicide or punishment wish immediately following.) A little pimp. $\mathrm{He}$ hates everybody in the world, because everybody hates him. $\mathrm{He}$ ain't got no friends. (This shows the germ of paranoia.)

"Men and women talk to me. Some are good and some are bad. He hears the voices of fellows from between the walls. Let me do cunnilingus and you put it in the paper. Sistershave coitus with them. Brothers and sisters having coitus around the corner. Do you want me to commit fellatio on you (hits me in genitals), do you want me to masturbate you for a dollar? He masturbated cops on the beach with his fist,

"Stink. He smells bad smells sometimes. I'm Kaiser Wilhelm the Great, the Greatest. That's what they tell you. The Dutch fight for you. No they didn't. ("Why did you say so then?") Well, you have to make up things. Steal an auto but don't get caught. He's damaged goods, in his rectum, they broke it. I'm a Catholic god. Don't commit fellatio on me. This kid is nutty."

He frustrated an attempt to make a spinal puncture believing it was a pederastic assault, "they pulled up my shirt and pulled down my drawers and did pederasty on me. They jabbed a needle into my back and set me on fire. This kid never had a friend and he hates all the world." When the physical examiner stripped him, he feared a sexual assault. "He wants to have intercourse with me, do fellatio on me, masturbate me." $\mathrm{He}$ tried to escape from the room, then recovered from his fear, be- 
came erotic and began to masturbate. Sometimes he started to leave my office, saying he was going home, and I had to lead him back to his chair and sit him down in it. He usually mistook this for a homosexual assault, but made hardly any resistance.

It was evident that he had burning sensations in many parts of his body, particularly the erogenous zones. He fingered his left nipple until it was big and stiff, and he occasionally masturbated.

It was not possible to keep him in the fairly open endocrine ward, because he tried to escape and also made sexual advances to the occupational therapist and women nurses.

Occupational therapy: His attempt to break out of our ward on the second day brought his short visit to an end. $\mathrm{He}$ was willing to try basket weaving but his diffuse energy prevented his concentrating on learning it. He continually dropped his work and wandered away, and failed to master the simplest weave.

Physical examination: Tall, slender, showing pronounced psychomotor activity. Muscular development poor. Actiniform eruption present over back and neck which are much scarred from old acne infections. Skin in general very poorly nourished. Genital hair tends to masculine type. A little tuft of hair in mid-sternal region. Genitalia normal. Abdomen protuberant. Heart very rapid. Reflexes not reliable.

Endocrine diagnosis: Hyperthyroidism.

Glandular therapy: Suprarenal gland was fed him. No change was noticed in his behavior.

Four months later: He was still talking steadily but in a very low tone of voice, and he was quieter physically. He was easier to control because he was much less restless. It was harder to talk with him however, for he seemed to be cut off more completely from outside stimuli. In a low, dull voice he talked of the same subjects, hugging, kissing, getting new brains and teats, sucking eyes, and wanting an automobile, a gift of money, and to go home.

Mental diagnosis: Manic depressive with schizophrenic features seems the best diagnosis for this unusual psychosis. After his disgrace in France he became "listless, depressed and 
melancholic," but later his behavior grew more manic in type, though he repeatedly whimpered and mourned throughout his restless activity. His actions were rather childish. Every few minutes he whooped like a boy at play, he noticed all the details of the environment and wanted to handle and examine everything, and occasionally he dived into a bed and kicked his heels in the air. The next moment he might be weeping at his face in the mirror and lamenting that he wanted to be washed clean. Often his emotion did not harmonize with the occasion. Like most of the schizophrenic cases he projected his difficulties and believed other men assaulted or wanted to assault him sexually, and he turned his perverse cravings into voices, yet throughout it all he had much insight and knew that if he could wash his mind clean he would be all right.

His perverse impulses ran the whole gamut, with incest, male and female perversions, and even such an infantile act as sucking a nipple. His history disclosed his inability to direct his libido to the opposite sex, thus leaving him in the childish bi-sexual stage in which his female component strove towards other males. On this account he made the devil who tempted him, a female. There was much craving left in the secondary erogenous zones.

\section{VINCENT}

History: He was an epileptic twenty-nine years old and was born defective. He could not coördinate well in any way. $\mathrm{He}$ enunciated with difficulty. $\mathrm{He}$ was badly crosseyed and could read only the big headlines of newspapers. All his movements were stiff and clumsy.

The family history was negative. The father was a prominent professional man, and the younger brothers were normal. The family tried to protect him from teasing, and his mother devoted herself to him, even telling him she would rather lose any of her other sons than lose him. She taught him at home, and he learned to read a little.

He had the first epileptic seizure at the age of nine. They became worse as he grew older. When he was twenty-seven he had a very severe one lasting over two hours. After it he was 
hallucinated and was removed to a hospital. $\mathrm{He}$ gradually emerged from the psychosis, but was left in this hospital. Half a year previous to his entering the endocrine ward his mother died.

Sex life: When he was eleven a girl over twenty played with him sexually, and he tried to have coitus and pederasty with her, but did not know how. He never had another heterosexual experience because he didn't care to. He was home most of the time and didn't get acquainted with girls and wasn't much interested in them.

As a boy he felt that erection and masturbation pulled his brain. After circumcision at twelve, erections did not cause this sensation, but at the moment of orgasm he could feel a pull on the brain and the temples, and then some pain over the eyes. When he was twenty-four he played sexually with a brother of twenty years. They masturbated each other and tried pederasty. The passive rôle hurt the patient and he allowed only coitus inter femora, but he committed pederasty on the brother several times.

For a year previous to his psychosis he had masturbated daily. He thought this was one of the causes of his breakdown, and stopped doing it oftener than once a month. During a visit away from the hospital he committed pederasty on a young boy.

After his mother's death he became more interested in other women. An occupational therapist feeling pity for his afflictions was kind to him, and he fell in love with the young woman and dogged her footsteps. "I'm so fond of her I can't keep her off my mind. I can't keep away from her. Since Mother's death I've gone more with girls." He was blissfully unaware that his abnormalities prevented other people from ever feeling any emotion toward him warmer than pity.

Fantasies: The severe seizure which preceded his psychosis he believed had been caused by his daily masturbation and his long worrying over his father's danger at the front in France. ("What thoughts did you have about your father?" $\mathrm{He}$ flushes.) "Perhaps I can tell you better some other time. Father and Mother were devoted to each other and didn't like to be separated. (He quotes some Bible references about the Golden Rule.) I worried over whether I'd ever see him again. 
I imagined his dead face in a box looking at me in his sleep. The household talked about the war till it got on my nerves. The spell lasted two and a half hours. I saw the Lord looking at me. He said I was one of his best sons, one of the best ever put out. Then he pulled me up into the sky. There was a multitude of angels. It was quite pleasant."

While in the psychosis he dreamed several times that he was a female having intercourse with a male. In one of the dreams his male partner was the sun. Always he could feel the male's semen enter his body. He also had the fantasy that male and female were joined together in his body, making him a combination of the two, and he drew a kind of swastika of four arms and legs united at one point which was his abdomen, and he named the four limbs north, east, south and west. North and east were above and to the right and were of heaven and good; south and west were below and to the left and were of hell and bad. To the right were five circles of stars and to the left one line of stars. This swastika became a nude man standing in a box with the pores of his skin as big as if punched by fingers, though which the devil tried in vain to inject evil into him.

These fantasies show his bi-sexuality and his craving to take a female sexual rôle, and also his resistance to it. Representing resistance we see, standing in the female symbol of a box, a man full of vaginas through which the devil (perverse impulses) tries vainly to inject evil (semen).

As he recovered he dreamed of being in a car crossing a burning bridge. It falls into the water and he cries for help. The Lord looks at him and gets three big locomotives to pull the car out. It then enters tunnels where he becomes master of all the world. He explained that fire stood for great fear. "When you disobey the Lord, you fear he will punish your spirit with firt." This dream seems to picture him falling through sin (fire) back into mother (water) and being rescued by three big locomotives (male potency) so that he can enter tunnels (vaginas), or in other words he struggles out of his mother fixation and establishes his heterosexual potency.

After his mother's death he had visions of seeing her standing beside God and smiling happily at him. Once he heard a 
voice which sounded like hers call out of the West, Oscar, come home, come," and he answered, "I'm coming as fast as I can." ("Do you have dreams or visions of your father?") No, there's no call for one. I saw my mother's spirit standing beside my father-my heavenly father. Mother was pleased because I was one of the best sons ever put out. My father was pleased too. ("Your father?") No, no, my heavenly father."

It is true that since his mother's death he has succeeded in turning his libido more toward younger women, as evidenced by his infatuation for the occupational therapist. "I dreamed I was to marry her. Another night I dreamed I was dead and she was looking at me in sorrow, for I was her husband." $\mathrm{He}$ never had had a dream of normal heterosexual intercourse.

General observations: Fortunately he seemed not to realize his defects, and was very happy and cheerful. He found something humorous in all about him except in the realm of religion and morality. His Bible was always handy though he could not read it himself, and he appointed himself monitor of the conduct of other patients and even the attendants. He reproved swearing severely and attempted to prevent other patients masturbating in the toilet. Sometimes he got knocked down for his pains, but his missionary enthusiasm always revived. He followed one about like a curious child and butted into any conversation no matter how private, and always had an opinion to offer on every subject. In spite of his inability to read ordinary print he kept accurate track of the date. "I just keep dates in my mind."

His spells came at irregular intervals and he had never noticed that they followed any particular emotion or state of mind. An aura always gave warning of their approach. "The nerves of my body go dead first-in my fingers and feet. There's a feeling in the left side of the brain, then over the forehead and eyes. The numbness creeps up my arms and legs. I see a buzzing of many lights, either all yellow or all white. They go around in a large circle like a pinwheel. My head buzzes and roars like a train of cars inside you. All the parts of my body get deader and deader, until it's all dead, and then I go unconscious.

"The first spell I had was when we had been waiting five days for father. Word came that he wouldn't be home for six 
months. I said I was tired of waiting and fell in a fit. I was seven or eight years old then." The father had been absent a long time and the boy had meanwhile been the center of his mother's life. She had been awaiting the father's return with joyous anticipation. I asked the patient if he thought jealousy had played any part in the spell, and he broke into sudden loud laughter. "I wouldn't be a bit surprised if that was the foundation of the whole thing, of my having these spells. Mother would hold me down during them so I wouldn't move around much. I'd be weak after them and she'd pay a good deal of attention to me. I think pressure on the brain and jealousy may have caused these spells." It will be recalled that the severe seizure which ushered in his psychosis came at a time when he had worried over his father's danger in France and had had visions of his corpse in a coffin. His spells in the hospital no one was able to connect with any particular emotion or incident.

Occupational therapy: He had parole and didn't work in the ward but liked to visit the occupational carpenter shop occasionally where, on account of his poor eyesight and incoördinate movements, he did very poor jig sawing and broke many saws, but enjoyed it immensely.

Physical examination: Slender type of skeleton. Oxycephalic skull. Arrest of development of lower jaw. Teeth irregular and notched. Hair distribution normal. Genitalia normal. Abdomen protuberant. Heart irregular and rapid. Bilateral internal strabismus. Chronic middle ear disease. Athetoid facial expressions. General incoördinations. Numerous tics and slightly hyperactive deep reflexes. Slurring speech defect which patient attributes to previous tongue adhesions.

Endocrine diagnosis: Dyspituitarism.

Glandular therapy: $\mathrm{He}$ was given desiccated pituitary (whole gland). Some observers thought his epileptic seizures occurred less often, but this was difficult to decide, for they had always been irregular.

Four months later: He seemed a bit duller.

Mental diagnosis: He was a defective and epileptic, who had recovered from a psychosis with schizophrenic features in which 
his wishes had been projected into visions and voices. He secured compensation for his actual sorry condition by causing the Lord to announce him as one of his finest creations, and after his mother's death he saw and heard her again. The usual perverse sexual cravings were also present.

Now he is emerging from the mother-fixation bi-sexual stage and turning his love impulses toward a permissible object, the occupational therapist. 


\section{CONCLUSIONS ON OCCUPATIONAL THERAPY}

With the exception of Irgocz, nearly every patient on the ward seemed to have improved to some extent before the beginning of glandular therapy. It is difficult to decide just what was responsible for this betterment. Probably it was a combination of things, the unusually cheerful ward with its sunny glassed-in piazza, the care of kindly and capable nurses and attendants, the encouraging presence of the occupational therapist with her pleasing personality, interesting work and play and more attention all around than the average patient in the institution was receiving.

Of the four patients who improved markedly before glandular therapy began, Lefferts and Nolan cannot be credited to occupational work because they did not do enough of it. O'Neil and Jackson, however, seemed to be drawn out of themselves and aided by it. The active men who had no parole of the grounds found occupational work a pleasant way to pass the time. The worried and dreamy patients worked only when urged. With the exception of the badly introverted Abrams, every man who got parole of the grounds preferred freedom outdoors to work indoors and dropped work partially or completely.

The work and play undoubtedly made many of the patients happier, but I believe that only in the cases of Jackson and O'Neil did they lend any considerable aid towards improvement or cure.

Occupational therapy however, is a most valuable indicator of a patient's condition. Any mental improvement or regression is quickly mirrored in his work. 


\section{CONCLUSIONS ON GLANDULAR THERAPY}

Feeding desiccated glands stimulated the patients in almost every case. In one or two instances this stimulation seemed to increase their troubles, and they became more irritable and upset, but as a rule it proved beneficial in varying degrees. Some gave the impression of being forced to extrovert and to notice the environment in spite of themselves; others seemed to develop a spontaneous normal interest in their surroundings.

The most spectacular change was in the convalescent Nolan, who out of abject laziness was suddenly transformed into a fairly energetic boy, interested in his daily work and even planning it ahead. His improvement lasted throughout the few weeks until he was discharged. Dixon was enabled to repress his perverse cravings for half an hour at a time, and thus obtained periods of respite from the torturing "influence" used on him. Tocci's depressions, which had come regularly two or three times a week, now occurred much less frequently and were not so deep, but this improvement disappeared in a few weeks. O'Neil and Quitner.continued their steady convalescence with no very apparent acceleration. But Riegel after a few weeks of glandular therapy improved considerably. For many months his condition had remained stationary in spite of hospital protection and occupational therapy.

At first the effects of gland feeding were so spectacular that we expected great benefit from it, but as time passed, the improvement gradually faded even while treatment was still being given. After it was stopped, the patients returned practically to their former condition with the exception of those who had previously begun to convalesce. Riegel started to regress before he was transferred to another hospital.

Although the effects of gland feeding seem to be temporary, this treatment may possibly be of great value in breaking into the so-called vicious cycle of mental disease, particularly in the eurly stages. A combination of thyroid stimulation and psychoanalysis might be an excellent method of attacking incipient schizophrenia. 


\section{CONCLUSIONS ON PSYCHOANALYTIC TREATMENT}

No cure or great improvement can be claimed as due mainly to psychoanalysis in these twenty-two cases. To be sure, my purpose was to study rather than treat the patients, but I did try to help six of them, Carhart, Dixon, Lefferts, Nolan, Purdy and Quitner. The old deteriorateds such as Engel, Foster, Garland, Irgocz, Jackson and Kimmel were beyond aid from this source. Mathews and Vincent had already recovered from their psychoses. Abrams, Bailey, Halsted, O'Neil and Riegel were too negative and resistant. Tocci was too inattentive in his elations, and inaccessible in his depressions, and the barrier of language separated us. Ulster had too much manic push to listen to anyone. Sabin in his depressed periods was very dull and his psychosis was of long standing. Unless a patient realizes he is sick and wishes to get well, the analyst has little chance to help him.

Purdy, though often suspicious, had considerable confidence in me and talked freely of his troubles. He got insight into his improper impulses and their projection and improved considerably so that I felt much encouraged. Then the old paranoid ideas obtruded and proved too fixed to remove. His remark is illuminating, that he did not want to talk with me for fear I would destroy his belief in his delusions and that he preferred to keep them. But he recovered sufficiently to obtain his freedom.

Lefferts wished to learn nothing new and would listen to no explanation. He knew all about it already and enjoyed many of his hallucinations. His stubborn conceit was probably an overcompensation for his inferior body and lack of physical courage. During his healthy interlude, coincident with the infection in his hand, I tried very hard to make him understand mental mechanisms, but his obstinate ignorance was impregnable. He had witnessed supernatural phenomena then, and now he no longer did; this was sufficient explanation for him. Because he had gained no insight whatever, it was easy for him to slip back again 
into the psychosis after he had recovered from the infection.

Nolan was of such limited intelligence and vocabulary that it was practically impossible to explain mental mechanisms to him. After his talks with me however, he lost his delusions and he was immensely relieved when I removed his fear of being pregnant. His psychosis was gone before he began glandular treatment.

Carhart was struggling desperately to suppress his unworthy cravings, but he could not overcome his resistance and make a clean breast of his troubles. I hoped to win his confidence enough to enable him to break down his reserve and talk freely with me, but I failed.

Dixon was perfectly willing to talk freely, but he had developed in self-defense such disgust for homosexual perversions that he could not face the possibility that cravings of this kind might originate in himself. Consequently he would not even consider the hypothesis of projection. He clung tenaciously to his belief in "influence" and gained no insight whatever.

Quitner, as compensation for a sense of physical inferiority, had built up great conceit of intellect and believed he knew more than the doctors. This attitude made him resistant to psychoanalysis. Furthermore, after the unpleasant cravings had been once more repressed, he so enjoyed the now innocuous conversation of his projected voices that he was reluctant to give them up. But he loved freedom even more, and when he saw that this schizophrenic habit stood between him and liberty he either concealed it or reasoned his way out of it. Probably psychoanalysis aided him in his recovery.

Although psychoanalytic treatment showed no conspicuous results in this particular group of men, I have seen other psychotic patients in St. Elizabeths greatly benefited by its use. 


\section{GENERAL CORRELATIONS}

The first two tables give the groups according to mental classification with the endocrine diagnosis following each name. and vice-versa the groups according to endocrine classification

I

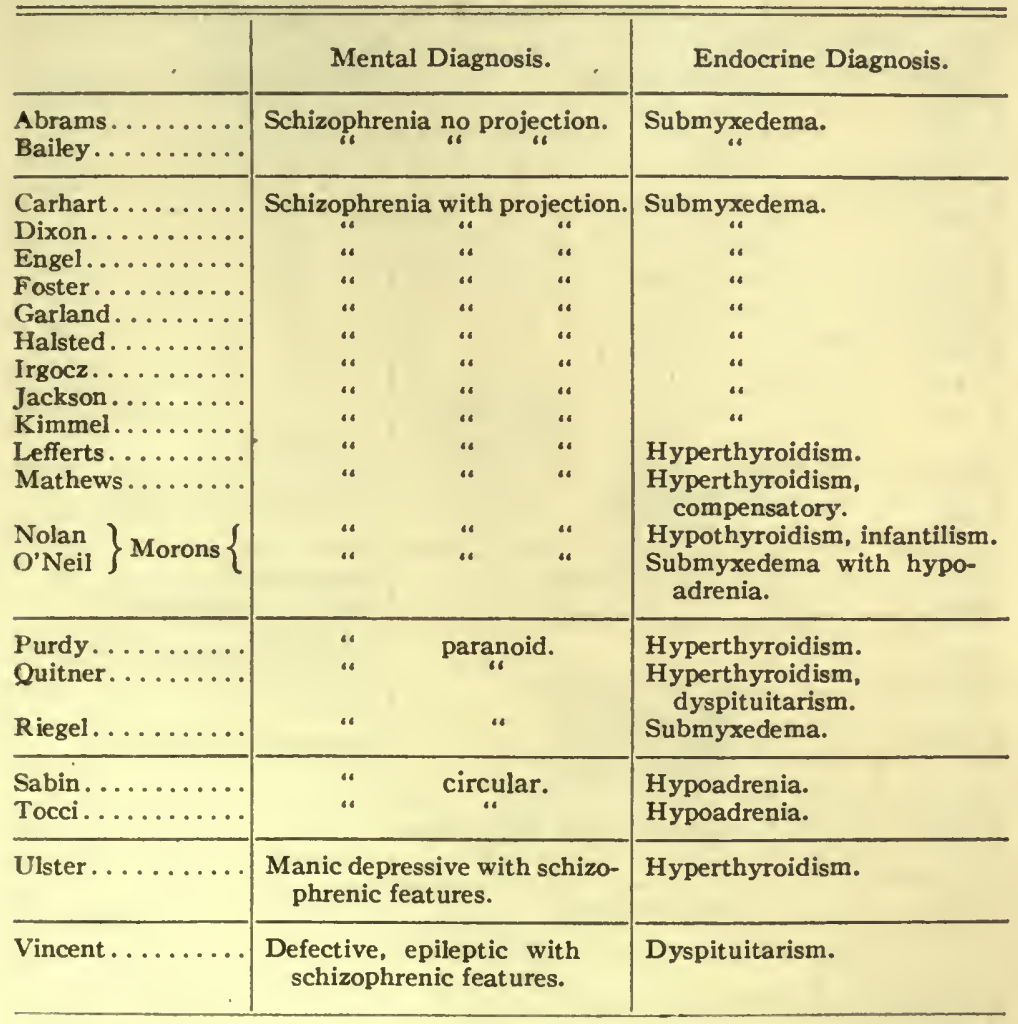

with the mental diagnosis following each name, while the last table gives briefly the facts of each individual case.

In order to see whether the percentage of each mental syndrome among our patients corresponded with the percentage 
among a large group of other psychotics, I took as control from a list of all the male first admissions in the New York State hospitals for the year ending June 30, 1917, those psychogenic types that corresponded roughly with our own. From the description of their method of diagnosis I judged that our two cases of schizophrenia circular and one case of manic depressive with

II

\begin{tabular}{|c|c|c|}
\hline & Endocrine Diagnosis. & Mental Diagnosis. \\
\hline 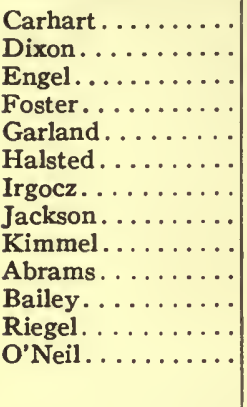 & 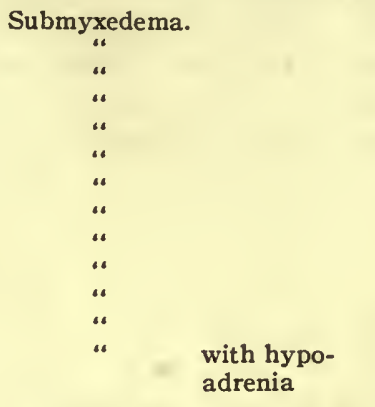 & 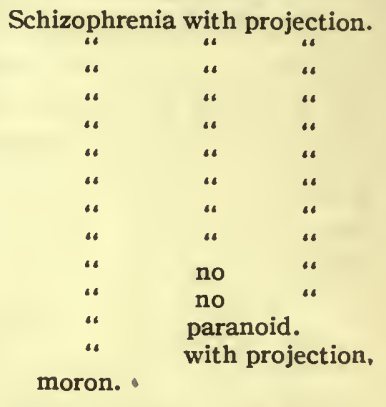 \\
\hline $\begin{array}{l}\text { Sabin. . } \\
\text { Tocci. . }\end{array}$ & Hypoadrenia. & Schizophrenia circular. \\
\hline 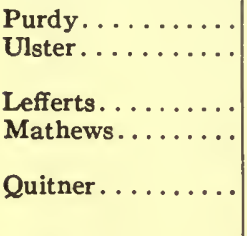 & $\begin{array}{l}\text { Hyperthyroidism. } \\
\text { “ } \\
\text { Hyperthyroidism, } \\
\text { compensatory. } \\
\text { Hyperthyroidism, } \\
\text { dyspituitarism. }\end{array}$ & $\begin{array}{l}\text { Schizophrenia paranoid. } \\
\text { Manic depressive schizo- } \\
\text { phrenia. } \\
\text { Schizophrenia with projection. } \\
\text { " } \\
\text { Schizophrenia paranoid. }\end{array}$ \\
\hline Nolan. & Hypothyroidism, infantilism. & with projection، \\
\hline Vincent & Dyspituitarism. & Epilepsy, schizophrenic. \\
\hline
\end{tabular}

schizophrenic features would in their diagnosis be called allied to manic depressive, that our schizophrenia with projection would be called dementia precox-hebephrenic or catatonic, and that our schizophrenia paranoid and simple schizophrenia without projection would be called dementia precox paranoid and dementia precox simple. Whether or not the New York state group contained endocrine disorders was not stated. 


\begin{tabular}{|c|c|c|c|c|c|c|c|c|c|}
\hline & 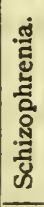 & 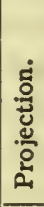 & 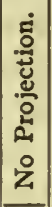 & 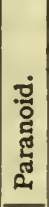 & 苞 & 总 & 完 & 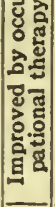 & Effects of Glandular Therapy. \\
\hline 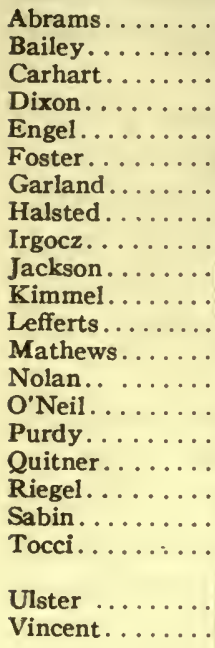 & 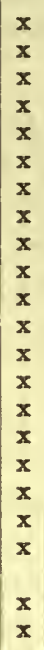 & $\begin{array}{l}\mathbf{x} \\
\mathbf{x} \\
\mathbf{x} \\
\mathbf{x} \\
\mathbf{x} \\
\mathbf{x} \\
\mathbf{x} \\
\mathbf{x} \\
\mathbf{x} \\
\mathbf{x} \\
\mathbf{x} \\
\mathbf{x} \\
\mathbf{x} \\
\mathbf{x} \\
\mathbf{x} \\
\mathbf{x} \\
\mathbf{x} \\
\mathbf{x}\end{array}$ & $x$ & \begin{tabular}{|l|}
$x$ \\
$x$ \\
$x$
\end{tabular} & $\begin{array}{c}x \\
x\end{array}$ & $\mathbf{x}$ & $\begin{array}{l}x \\
x\end{array}$ & $\mathbf{x}$ & $\begin{array}{l}\text { Improved. } \\
\text { Improved. } \\
\text { No treatment. } \\
\text { Considerably improved. } \\
\text { More active and irritable. } \\
\text { Improved. } \\
\text { Improved. } \\
\text { No effect. } \\
\text { Improved. } \\
\text { Improved. } \\
\text { No treatment. } \\
\text { No treatment. } \\
\text { Improved. } \\
\text { Remarkably improved. } \\
\text { Recovery accelerated? } \\
\text { No treatment. } \\
\text { Recovery accelerated? } \\
\text { Improved. } \\
\text { No treatment. } \\
\text { Marked temporary improve- } \\
\text { ment. } \\
\text { No effect. } \\
\text { No effect. }\end{array}$ \\
\hline
\end{tabular}

The following table gives the comparisons between our group and this large group:

\begin{tabular}{|c|c|c|c|c|}
\hline \multirow[t]{2}{*}{ - } & \multicolumn{2}{|c|}{ New York. } & \multicolumn{2}{|c|}{ Endocrine. } \\
\hline & $\begin{array}{l}\text { Number } \\
\text { of Cases. }\end{array}$ & $\begin{array}{l}\text { Percent- } \\
\text { age. }\end{array}$ & $\begin{array}{l}\text { Number } \\
\text { of Cases. }\end{array}$ & $\begin{array}{l}\text { Percent- } \\
\text { age. }\end{array}$ \\
\hline Manic depressive. & $28 \mathbf{r}$ & 18 & 0 & 0 \\
\hline Allied to manic depressive. & 89 & 6 & 3 & $r_{4}$ \\
\hline Symptomatic depressions. . . . . . . . . & 9 & $\mathbf{x}$ & o & 0 \\
\hline \multicolumn{5}{|l|}{ Dementia precox: } \\
\hline Paranoid....... & 403 & 27 & 3 & 14 \\
\hline Simple........ & 95 & 6 & 2 & 9 \\
\hline Hebephrenic and catatonic. & 296 & 19 & Ir & 50 \\
\hline Allied to dementia precox.......... & 121 & 8 & $\mathbf{0}$ & 0 \\
\hline Paranoia............... & $6 r$ & 4 & o & o \\
\hline Epileptic..................... & 74 & 5 & I & 4 \\
\hline \multirow[t]{2}{*}{ Mental deficiency $\ldots \ldots \ldots \ldots \ldots \ldots$} & $9 \mathbf{r}$ & 6 & 2 & 9 \\
\hline & & 100 & 22 & 100 \\
\hline All dementia precox. & 915 & 60 & 16 & 73 \\
\hline All dementia precox and paranoia & 976 & 64 & I6 & 73 \\
\hline
\end{tabular}


The comparison made above seems to indicate that the distribution of cases, which had been selected primarily or exclusively for endocrine conditions, does not correspond with the distribution of cases of functional or so-called functional character in the admissions into the New York state hospitals.

The most striking difference is that half of our patients would be called hebephrenic or catatonic dementia precox, while only 19 per cent. of the New York state hospital patients are included in that group.

On the other hand the New York paranoid precox group is 27 per cent. of the the total while ours is only I4 per cent.

Even were it true that in New York some of our hebephrenics and catatonics might be called paranoids, still they would largely exceed the percentage in New York. Our total percentage of schizophrenia is greater than their percentage of dementia precox and paranoia combined.

It is particularly interesting that we did not have one single case of pure manic depressive insanity although nearly 23 per cent. of our patients suffered from hyperthyroidism. We had $\mathrm{I}_{4}$ per cent., however, which had some manic depressive symptoms, while in New York there are only 6 per cent. in this classification. But if we add together New York's manic depressive, allied to manic depressive, and symptomatic depressions, they outnumber ours 25 per cent. to 14 per cent.

We had no case of pure manic depressive, paranoia or symptomatic depression. In simple dementia precox, epileptic psychoses, and psychoses with mental deficiency our percentages are approximately those of New York.

Of course I realize that one case more or less in our group would change the percentages considerably, so that they cannot be taken as fully characteristic, with the exception of our schizophrenia with projection. They form a surprisingly large percentage, nearly three times as great as the corresponding group in New York.

It may be objected that a comparison with the New York state hospitals alone is not enough but $I$ wish to call attention to the fact that the reports of various states in other years have shown very striking similarity in the percentages of distribution 
in communities throughout the East and in other sections of the country where the conditions of living are practically the same, so I have considered myself justified in taking New York as typical of the more populated sections of the nation. The main reason for selecting New York was because of its excellent official reports wherein the statistics for all the state hospitals are combined and clear description is given of their methods of diagnosis. 


\section{GENERAL CONCLUSIONS}

Every case was schizophrenia or had schizophrenic features.

The two cases of simple schizophrenia, that is, in which the patients introverted without projecting their impulses, were both submyxedema.

The two cases with features of circular insanity were both hypoadrenia.

The hyperthyroids as a whole seemed to be more extroverted and to keep in closer contact with reality than the other types.

The feeding of desiccated thyroid gland seemed to reduce introversion and to cause the patient to come into closer contact with the environment.

Most of these patients showed or gave indications of the struggle with perverse impulses of the creative instinct, that is, the sexual conflict which the Freudian school believes to be the cause of psychogenic disorders. 


\section{DISCUSSION}

Although it has long been recognized that there are mental disturbances associated with endocrine changes such as menstruation and the menopause, still very little has been done to find a definite correlation of special mental symptoms or groups of symptoms with the physical disorders of the ductless glands. So far as I am aware, this is the first serious attempt to psychoanalyze a group of psychopathic endocrine patients and thereby get a deeper insight into their mental condition than is ordinarily given in previous attempts at correlation of mental disturbances and endocrine disorders. While previous investigators have often given excellent reports in great detail on the condition and function of the ductless glands, their descriptions of mental symptoms have usually been meager and superficial.

Wechsler ${ }^{4}$ has been one of the few who have given better pictures of the mental side, but even his article on the psychoneuroses and the internal secretions is more of a suggestion than a thorough study. Barham ${ }^{5}$ has given a psychoanalysis of a single case of insanity with myxedema. After the myxedema had been cured, the mental disturbances broke out anew as soon as the patient returned to her former unfavorable environment.

As a result of the present great interest in the endocrine glands and their relation to the various functions of the organism; they have been studied from many angles, and a number of investigators have touched more or less on our phase of the problem. Several of them have remarked that the adrenal and sometimes the thyroid glands weighed less among the insane. Mott ${ }^{6}$ found the adrenals atrophied in many post mortem examinations but laid it to the physical disease that caused death

4 Wechsler, I. S., The Psychoneuroses and the Internal Secretions, Neurological Bulletin, vol. 2, number 199 (May, 1919).

5 Barham, G. H., Insanity with Myxedema, Journal of Mental Science, vol. 58, number 226 (1912).

- Mott, F. W., Suprarenal Glands in Nervous and Other Diseases, Archives of Neurology (London), vol. 3, p. 123 (1907). 
rather than to the mental disease. Kojima ${ }^{7}$ reported after a very detailed study of over one hundred cases that the thyroid weighed less among the insane. Of course, our classification according to endocrine dysfunction was not made from observations on the morbid anatomy of the glands.

Rossi $^{8}$ found in nine cases of manic depressive insanity following influenza that there was marked adrenal insufficiency. In six other manic depressive cases uncomplicated with influenza there was similar adrenal insufficiency. The use of adrenalin had good results. Prior $^{9}$ reported that among epileptics there was very frequently degeneration in the adrenal cortex. Phillips ${ }^{10}$ connected sporadic goiter with hyperthyroidism, excitement, agitation, and manic depressive insanity, and connected endemic goiter with hypothyroidism, apathy, indifference and dementia precox.

Laignel-Lavastine ${ }^{11}$ draws correlations between abnormal mental states and endocrine disorders. With mania he connects disturbances of thyroid, adrenals, and ovaries. This quite tallies with our results, for our cases with manic features were hyperthyroid and hypoadrenal. As our patients were all male, the ovaries did not figure. With dementia precox he connects testicles, ovaries, and pituitary. Our experience is totally different, for our precox cases showed disorders of thyroid and adrenals. With epilepsy he associates thyroid, parathyroids, testicles and ovaries, while our one epileptic, Vincent, showed dyspituitarism. $\mathrm{He}$ cites genital perversions, not stating whether they are fan-

' Kojima, M., The Ductless Glands in ro Cases of Insanity with Special Reference to Hypothyroidism. Studies on Endocrine Organs of Dementia Precox, Archives of Neurology (London), vol. 7 (1918).

${ }^{8}$ Rossi, S. C., Influenza, Suprarenal Insufficiency and Manic Depressive Psychoses, Anales de la Facultad de Medicina (Montevideo), vol. 4. number 12, p. 801 (Dec., r919).

${ }^{9}$ Prior, G. P. U., Mental Cases of Endocrine Considerations, Journal of Mental Science (London), vol. 66, number 272 (Jan., 1920).

10 Phillips, N. R., Goiter and the Psychoses, Journal of Mental Science (London), vol. 65, p. 235 (Oct., 1919).

11 Laignel-Lavastine, M., The Internal Secretions and the Nervous System, Nervous and Mental Disease Monograph Series No. 30, 1919, p. 32. 
tasied or actual, and connects them with ovaries, testicles, prostate, and adrenals. Our cases who confessed to having committed perversions (excluding Sabin and his one unsuccessful attempt at puberty) had hyperthyroidism and dyspituitarism. If only fancied perversions are meant, probably every one of our cases would be included.

Prior states that mentally deficient patients after being fed for several months on thyroid and pituitary extracts gained percentages in the Binet-Simon intelligence tests several years in advance of the grade they reached before treatment began.

Of our two morons Nolan, who had already recovered from his psychosis, took desiccated thyroid and gained remarkably in energy and intelligence. His mental age, according to the Terman test, advanced from eight years seven months to nine years eleven months, and his intelligence quotient from 54 per cent. to 62 per cent. O'Neil was emerging from his psychosis before he began to take desiccated suprarenal, and the speed of his convalescence did not seem to change during the gland feeding. His gains in intelligence were practically the same as Nolan's; eight years to nine years three months, and 50 per cent. to 58 per cent.

Cushing ${ }^{12}$ draws attention to the close relation between the function of the anterior lobe of the pituitary and the gonads, since if one is hyper or hypoactive the other is also, and thinks the psychoanalytic school should take cognizance of this in their theories of infantile sexual complexes. He believes that sexual precocity or backwardness, due to disturbances of these glands, might well give rise to abnormal sexual mentality.

Jelliffe deals with the same problem as follows: "Variations in the actual endocrine organs undoubtedly alter the reactivity of the individual, so that certain complexes, always difficult in themselves even under the best of circumstances, are not as well dealt with by reason of this (for lack of a better term) what may be called 'sensitiveness.' We know the complexes are a necessary part of everyone's evolution. Why should fixation and regression

12 Cushing, Harvey, Psychic Disturbances Associated with the Ductless Glands, American Journal of Insanity, vol. 69, p. 965 (1913). 
occur with greater intensity in some people than in others? Does a defective hyper-thymus-gonadal group handle an incest complex more inadequately because of the early appearance of the craving, thus forcing a repression before its time, with its consequent readjustment to a narcissistic libido fixation? What does a thyroidal-adrenal group do with the same situation? If the psychical factors, and the knowledge of the accidents, traumata, etc., can be integrated with the constitutional factors, I feel sure we will be on our road to a real psychiatry.

"For the present all we can hope for is to indicate the lines along which the correlations can be made. The real indices of endocrine adjustments are far from being well known. We have a few facts bearing on extremes, the means are in a jumble. Psychoanalysis also is in a similar situation. But it does deliver definite qualities-as for quantity, that is, the force behind the wish-that is still an important problem. Two patients may deliver us two similar incest dreams. On the face of them they have come through the censorship with quite similar distortions and displacements-yet they may have behind them dynamic intensities of great variation, so that one patient has awakened refreshed, shall we say satisfied, the other disturbed, diarrheal and all cramped up; the dream has only partly satisfied the wish. Hence the quantitative factor is in great need of comprehension. This is a problem for the future."

152 WEST 58th STREET, NEW YoRK, N. Y. 


\title{
The
}

\section{Psychoanalytic Review}

\author{
F Fournal Devoted to an \\ Understanding of Ibuman conouct
}

RDITED AND PUBLISHED BY

WILLIAM A. WHITE, M.D., and SMITH ELY JELLIPPE, M.D.

\section{CONTENTS}

ORIGINAL ARTICLES

A Case of Paranoid Dissociation. Major Owen A. R. Berkeley-Hill.

Some Applications of the Inferiority Complex to Pluralistic Behavior. LORINE PruetTe.

A Psychopathological Study of Franz Molnar's Liliom. Gregory Stragnell. Conversion Epilepsy. Edward H. ReEde.

Epileptic Traits in Paul of Tarsus. Cavendish Moxon.

A Case of Anxiety Neurosis with Obsessions. I. B. Diamond. ABSTRACTS: Varia. Book Reviews.

Issued Quarterly: $\$ 6.00$ per Volume, Single Numbers, $\$ 1.75$

Foreign, $\$ 6.60$

\section{COPYRIGHT 1922}

by the

NERVOUS AND MENTAL DISEASE PUBLISHING COMPANY

41 NORTH QUEEN STREET, LAITCASTER, PA.,

and

Serial No. $33 \quad 3617$ loth ST., N. W., WASHINGTON, D. C. 


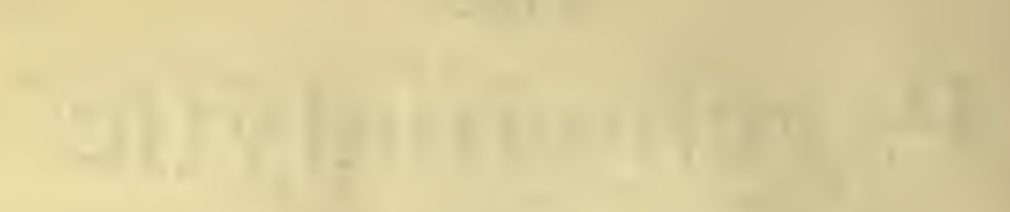

$$
4 x=1907
$$




\section{UNIVERSITY OF CALIFORNIA LIBRARY \\ Los Angeles}

This book is DUE on the last date stamped below.

SEP 161966

NOV 29 RECD

DEC $13196 \hat{6}$

$\operatorname{Tan} 17,67$

FER 22 REED

BOMED CEC 1276

',

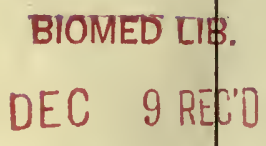

35. The Si nific nce of P. hoanal, is for the Meatal Scieaces. Os.on By lirs. O. Ra k lind D. H. Sachs.

24. Org Inferitity nd its Psychical Compensation. 12.00, Fg DE. Alfred Adler.

25. The History of the Pychoanlytic Mevement. \$1.00. By Prif S reud.

20. Te lingre of Psychoaraly is. (2] C.tici n, 19204i \$2 50. By Dr. Smith $\mathrm{E}$ y Jelliffe.

27. Vegetative Netrology. \$2 50. By Dr. H. Hig e ,

28. Tile Autinmc Fun ions and the Pers nalitv. \$3 oo By Dr. dwarl' J. Kempf.

29 A Study of the Merit 1 Life of the Child. \$2.0 By Dr H. Von Hug-Helimuth.

30. Internal Secretion and the Nervous System. 81.00. By D8. M. Laignel-Lavastlne.

3x. Sleep Walking and Moon Wa king. \$2.00. By Dr-J. Sadger.

32 Foundatio s of Pych'atry. $\$ 300$. By Dr. Wm. A White. 
